Cornell Law Library Scholarship@Cornell Law: A Digital Repository

Cornell Law Faculty Publications

Faculty Scholarship

4-1-1996

\title{
Incidental Burdens on Fundamental Rights
}

Michael C. Dorf

Cornell Law School, michaeldorf@cornell.edu

Follow this and additional works at: http://scholarship.law.cornell.edu/facpub

Part of the Constitutional Law Commons

\section{Recommended Citation}

Dorf, Michael C., "Incidental Burdens on Fundamental Rights" (1996). Cornell Law Faculty Publications. Paper 105.

http://scholarship.law.cornell.edu/facpub/105

This Article is brought to you for free and open access by the Faculty Scholarship at Scholarship@Cornell Law: A Digital Repository. It has been accepted for inclusion in Cornell Law Faculty Publications by an authorized administrator of Scholarship@Cornell Law: A Digital Repository. For more information, please contact jmp8@cornell.edu. 
Content downloaded/printed from HeinOnline (http://heinonline.org)

at Tue Nov 25 19:29:15 2008

Citation: 109 Harv. L. Rev. 1995-1996

From the HeinOnline License Agreement:

Licensees are granted a personal, non-exclusive, non-transferable, limited license to access the on-line, electronic archive of journals and other materials provided by HeinOnline (the 'Database'), and to download or print any portion or portions of content of the Database ('Materials'), primarily for your own use, according to the terms of this Agreement. This license includes:

(a) The right to electronically display Materials retrieved from the Database on your computer terminal;

(b) The right to download Materials by means of the download commands of the HeinOnline website and to store a single copy of Materials in a machine-readable form on your computer; and

(c) The right to print Materials by means of the printing commands of the HeinOnline website and to create a single print of Materials downloaded by means of the downloading commands of the HeinOnline website.

Except as specifically provided above, you are prohibited from downloading, storing, reproducing,transmitting, displaying, copying, distributing, or using any portion of the Database. Without limiting the preceding sentence, you shall not download or print an entire issue or issues of a publication or journal within the Database. You may contact HeinOnline by telephone or in writing in order to obtain a printed copy of one or more entire issues of such a publication or journal subject to payment of any applicable charge.

Other terms apply to this subscription. See the complete license at heinonline.org. 


\title{
HARVARD LAW REVIEW
}

\author{
ARTICLES
}

\section{INCIDENTAL BURDENS ON FUNDAMENTAL RIGHTS}

\author{
Michael C. Dorf
}

\section{TABLE OF CONTENTS}

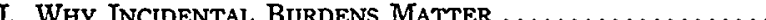

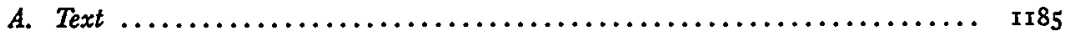

B. History and Structure.................................. II86

C. Normative Considerations .............................. II94

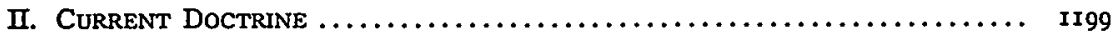

A. Incidental Burdens on Speech ............................ 1200

B. Incidental Burdens on Free Exercise of Religion .................. 12 Io

C. Incidental Burdens on the Unenumerated Right to Privacy............ I2I9

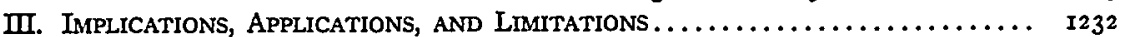

A. Application of the Substantiality Threshold to Targeted Burdens ........ 1233

B. Incidental Burdens and Facial Challenges ..................... 1240

C. The Substantiality Threshold ............................ 1243

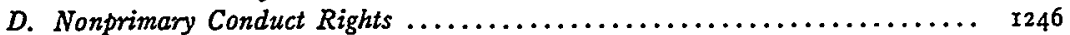

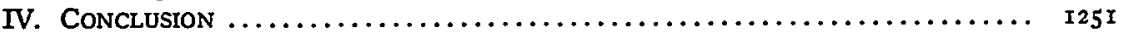




\title{
INCIDENTAL BURDENS ON FUNDAMENTAL RIGHTS
}

\author{
Michael C. Dorf*
}

\begin{abstract}
Nearly every governmental action has the incidental effect of burdening some fundamental constitutional right. In this Article, Professor Dorf argues that constitutional text, history, and structure, as well as normative considerations, require that courts treat these burdens seriously. How, though, can government recognize these incidental burdens without rendering itself powerless to achieve its legitimate ends?

Professor Dorf analyzes the Supreme Court's approach to incidental burdens on free speech, free exercise of religion, and privacy rights. In these areas, he discerns a tendency to apply close scrutiny to incidental burdens that are "substantial." He then argues that the nature of the impinged right should also influence the Court's approach to an incidental burden.

Finally, Professor Dorf reexamines common understandings of the distinction between direct and incidental burdens. He contends that his proposed framework ought to be applied not only to incidental burdens, but also to direct burdens on conduct facilitating the exercise of a fundamental right. Burdens on equality norms, however, need not be substantial to elicit close scrutiny.
\end{abstract}

GUNDAMENTAL constitutional rights ${ }^{1}$ are burdened in two principal ways. First, the government sometimes singles out protected activity for disadvantageous treatment. For example, a state statute might specifically prohibit flag-burnimg ${ }^{2}$ or the use of contraceptives. ${ }^{3}$ Second, the government sometimes enforces a law that does not, on its face, regulate protected conduct, but that has the incidental effect of burdening a right to engage im such conduct under some circumstances. For example, a state might apply its law prohibiting drug use

* Associate Professor, Columbia University School of Law. I am grateful for the comments and suggestions of Ashutosh Bhagwat, Vincent Blasi, Sherry Colb, Kent Greenawalt, Julie Hilden, John Manming, Molly McUsic, Henry Monaghan, Gerald Neuman, Allan Stein, and Laurence Tribe. I also benefited from my participation in the Internet discussion group Religionlaw and wish to thank the other participants, especially Eugene Volokh, organizer of the list. I received able research assistance from Lorenzo Bivans and Stacy Fols.

1 When I speak of rights in this Article, I generally mean rights to engage in primary conduct, such as speech, assembly, religion, abortion, and so forth. I have elsewhere contrasted rights to engage in primary conduct with procedural rights, which can only be exercised in institutional fora created by the government. See Michael C. Dorf, Facial Challenges to State and Federal Stalutes, 46 STAN. L. REv. 235, 265-66 (r994) (characterizing the Fifth Amendment right against compelled self-incrimination and the right to vote in most government-run elections as procedural rights). However, there exist rights that do not neatly fit into either category, such as the right to own and possess private property and the right to equal protection of the laws. I briefly discuss the proper treatment of rights such as these in section III.D.

2 See Texas v. Johnson, 49 r U.S. 397,399 (1989) (invalidating a conviction for violation of Texas's fiag desecration statute).

3 See Griswold v. Connecticut, 38r U.S. 479, 485-86 (1965) (invalidating a Connecticut law prohibiting the use of contraceptives by married couples). 
to Native Americans who ingest peyote as part of a religious ceremony. 4

Let us call these two types of burdens direct and incidental, respectively. 5 From the perspective of a rightholder, the severity of a law's impact has no necessary connection to whether the law directly or incidentally burdens the right's exercise. Direct burdens can be trivial - for example, a one-penny tax on newspapers that publish editorials critical of the government - whereas conversely, incidental burdens can be extremely harsh - for example, applying a prohibition against wearing headgear in the military to an Orthodox Jew. ${ }^{6}$

Nevertheless, Supreme Court precedent sharply distinguishes between direct and incidental burdens. ${ }^{7}$ A law imposing a direct burden will be permitted to override ${ }^{8}$ a fundanental right only if the law is

4 See Employment Div. v. Smith, 494 U.S. 872, 890 (1990) (finding no infringement of the First Amendment's free exercise right when the state denied unemployment benefits to Native American workers who were dismissed from their jobs because of their sacramental use of peyote, on the ground that the state's generally applicable criminal narcotics law prohibited the use of peyote).

5 These two categories are closely related to the two "tracks" of free speech analysis identified by Laurence Tribe, see Laurence H. Tribe, American Constitutional Law $\$$ i2-2, at 789-94 (2d ed. 1988), although the direct/incidental distinction applies to rights generally, not only to First Amendment rights.

6 See Goldman v. Weinberger, 475 U.S. 503, 509-ro (rg86) (upholding the application of military dress regulations to prohibit an Orthodox Jew from wearing his yarmulke indoors).

7 See infra Part $\Pi$. Distinguishing between direct and incidental burdens can require careful parsing of the acts permitted and forbidden. See, e.g., Church of the Lukumi Babalu Aye, Inc. v. City of Hialeah, II3 S. Ct. 2217, 2228-29 (I993) (examining coverage of and exceptions to a collection of local ordinances proscribing ritual animal sacrifice and finding that, in the aggregate, the ordinances impermissibly targeted the free exercise of religion by adherents of the Santeria faith).

8 Rights theorists use a convention under which a right is infringed when the government fails to perform its correlative duty, a right is violated when it is infringed without sufficient justification, and a right is overridden when it is infringed justifiably. See Alan Gewirth, Are There Any Absolute Rights?, in THEORIES of RIGHTS 91, 92 (Jeremy Waldron ed., 1984); see also Frederick Schauer, A Comment on the Structure of Rights, 27 GA. L. REv. 415, 425 n.38 (r993) (adopting the infringement/violation convention). 
narrowly drawn to serve a compelling interest. 9 In contrast, laws imposing incidental burdens trigger inore deferential judicial scrutiny. ${ }^{10}$

The doctrinal distinction between direct and incidental burdens rests partly on a floodgates concern. Nearly every law will, in some circumstances, impose an incidental burden on some right. In the free speech context, for example, incidental burdens include: "environmental and minimum wage laws that raise the price of newspapers, thus dampening public debate; laws that convert public parks to parking lots, thus eliminating public forums; and laws that tax income, thus reducing the amount of money individuals have to spend on expressive activities."11 The obvious constitutionality of the government action in these examples stands as a challenge to those who would construct a doctrine that takes seriously the incidental burdens in the peyote case, the yarınulke case, and other intuitively troubling cases. How can the law control the floodgates and still capture our intuition that some incidental burdens pose severe constitutional problems?

Incidental burdens on free speech and religion have been the subject of numerous cases and academic analyses. Courts and commentators alike have analyzed imcidental burdens on free speech as a species of content-neutral regulation. ${ }^{12}$ The Supreme Court's treatinent of "neutral" laws that burden religious practice ${ }^{13}$ has undergone withering academic criticism ${ }^{14}$ and was recently superseded by a federal statute. ${ }^{15}$ Less widely understood, however, are the common features shared by imcidental burdens on different rights. For illustrative purposes, this Article examines the case law and academic literature concerning three important riglits to engage in primary conduct: free

9 See, e.g., Boos v. Barry, 485 U.S. 3 I2, 32 I (I988) (holding that content-based speech restrictions must be "necessary to serve a compelling state interest and . . . narrowly drawn to achieve that end" (quoting Perry Educ. Ass'n v. Perry Local Educators' Ass'n, 460 U.S. 37, 45 (Ig83)) (internal quotation marks omitted); Moore v. City of E. Cleveland, 43I U.S. 494, 499 (I977) ("WW]hen the government intrudes [on a fundamental right], this Court must examine carefully the importance of the governmental interests advanced and the extent to which they are served by the challenged regulation."). The joint opinion in Planned Parenthood v. Casey, 505 U.S. 833 (I992), stands as a potential exception to this general principle. It grants constitutional protection to the decision whether to have an abortion but tests restrictions on the abortion right under an "undue burden" standard that differs in significant ways from conventional strict scrutiny. See id. at 878-79 (joint opinion of O'Connor, Kennedy \& Souter, JJ.). In section II.C and Part III below, I attempt to reconcile the approach of the three-Justice opinion in Casey with conventional strict scrutiny, but for now, it will suffice to treat abortion as sui generis and focus on other fundamental rights.

10 See infra Part II.

11 Geoffrey R. Stone, Content-Neutral Restrictions, 54 U. CHr. L. Rev. 46, 105 (1987).

12 See, e.g., David S. Day, The Incidental Regulation of Free Speech, 42 U. MIAMI L. REv. 491, 493 (I988); Stone, supra note II, at I05-I4.

13 See, e.g., Employment Div. v. Snith, 494 U.S. 872, 888-90 (1990).

14 See, e.g., Michael W. McConnell, Free Exercise Revisionism and the Smith Decision, 57 U. CHI. L. REv. IIOg, IIII (I990) (arguing that $S$ mith is inconsistent with constitutional text, history, precedent, and theory).

15 See Religious Freedom Restoration Act of I993, 42 U.S.C. § 2000bb (Supp. V I993). 
speech, free exercise, and the right of privacy. ${ }^{16}$ The Article identifies and defends a general approach to incidental burdens, and it concludes that laws having the incidental effect of substantially burdening fundamental rights to engage in primary conduct should be subject to heightened scrutiny.

In Part $I$ of this Article, $I$ discuss whether, in liglt of the risk of subjecting numerous, otherwise valid exercises of government power to searching judicial scrutiny, constitutional law ouglit to consider incidental burdens as posing any real problem at all. I argue that, despite the strength of this concern, the best understanding of constitutional text, history, structure, and purpose ${ }^{17}$ requires that incidental burdens be treated as real infringements of rights.

The argument in Part $I$ is both imterpretive and normative. Initially, I contend that constitutional text, history, and structure point toward - but do not compel - an interpretation that recognizes incidental burdens as infringements on rights. Although a bill of rights is logically consistent with protection against only direct burdens, I contend in Part I that the best understanding of the Constitution's juxtaposition of powers and rights affords protection against incidental burdens as well. That juxtaposition suggests that the rights protected by the Constitution are protected even when Congress (or, since the enactinent of the Fourteenth Amendinent, a state) exercises a concededly legitimate power.

Normative considerations also support the inference that constitutional rights protect agamst incidental as well as direct burdens. The two most common justifications for recognizing rights both lead to the conclusion that imcidental burdens should count as infringeinents of rights. First, the nonconsequentiahst treats the Constitution as protecting what are often called "rights as trumps."18 Under such a view, a right blocks the pursuit of otherwise legitimate powers or interests, regardless whether the burden is direct or incidental. Second, a consequentialist justification for rights typically rests on the judgment that soine individual interests - designated as rights - outweigh the competing interests of the society as a whole. Because the strength of the individual interest rarely depends on whether the government seeks to override it directly or incidentally, the consequentialist decision to rec-

16 Most of the Supreme Court's discussion of incidental burdens occurs in free speech and free exercise cases. I also focus on the right of privacy because Planned Parenthood v. Casey, 505 U.S. 833,869 (1992) (joint opinion of O'Connor, Kennedy \& Souter, JJ.), suggests - perhaps inadvertently - a useful approach to the general problem of incidental burdens.

17 Cf. Philip Bobbitt, Constitutional Interpretation I2-13 (Ig9I) (identifying historical, textual, structural, doctrinal, ethical, and prudential "modalities" of constitutional argument); Richard H. Fallon, Jr., A Constructivist Coherence Theory of Constitutional Interpretation, I0o HARV. L. REV. II89, II89-90 (Ig87) (discussing constitutional arguments based on text, framers' intent, theory, precedent, and policy).

18 Ronald Dworkin, Rights as Trumps, in Theories of Rights, supra note 8, at I53, 153. 
ognize a primary conduct right generally ought to confer protection against incidental as well as direct burdens. ${ }^{19}$

Nevertheless, as I note at the end of Part I, recognizing that incidental burdens are real burdens does not necessarily lead to the conclusion that every incidental burden should trigger heightened scrutiny. The remainder of the Article addresses the question of how the law does, and how it should, protect rightholders against incidental burdens and yet still avoid the floodgates problem.

In Part II, I describe and analyze existing doctrine with respect to incidental burdens on free speech, free exercise, and privacy rights. ${ }^{20}$ At least formally, the Supreme Court requires intermediate scrutiny of laws that impose an incidental burden on free speech, although in practice, the standard apphed often appears to be quite deferential. ${ }^{21}$ As a matter of constitutional law, the Court has essentially abandoned judicial review of neutral laws that burden the constitutional right to free exercise of rehion. ${ }^{22}$ Cases involving incidental burdens on unenumerated rights do not tend to reach the courts with any regularity - perhaps because lawyers and primary actors have assumed that the Court would not take seriously the clain that a generally applicable law might impose an impermissible incidental burden on such a right. In short, due to its fear that taking incidental burdens seriously would vastly expand judicial power to scrutinize legislation, the Court for the inost part treats incidental burdens as largely irrelevant for constitutional purposes.

There are, however, exceptions. Although not entirely self-consciously, the Court has closely scrutinized incidental burdens that it deeins substantial. In the course of describing the current doctrine governing incidental burdens in the free speech, free exercise, and right to privacy contexts, I identify a substantiality threshold in each of these areas.

19 One may therefore treat the Constitution as if it protects rights as trumps and still remain agnostic about the question whether the Constitution really treats rights as trumps - a very difficult question which is outside the scope of this Article. See James E. Fleming, We the Exceptional American People, in Const. Commentary 355, 357 (1994) (arguing that the convincing case for treating the Constitution as fundamentally democratic and secondarily rights-protective has yet to be made).

20 As I have noted elsewhere, these categories comprise nearly all the rights to engage in primary conduct that existing doctrine treats as fundamental. See Dorf, supra note I, at 269.

21 See Stone, supra note II, at 50-52 (observing that, despite the Supreme Court's use of language suggesting heightened scrutiny of time, place, and manner restrictions and content-neutral restrictions on speech mixed with action, the Court often applies a deferential standard in such cases).

22 See Employment Div. v. Smith, 494 U.S. 872, 890 (1990). Congress responded to Smith by passing the Rehioious Freedom Restoration Act of I993, Pub. L. No. I03-I4I, I07 Stat. 1488 (codified at 42 U.S.C. $\$ 2000$ bb (Supp. V 1993)), which mandates that laws imposing incidental as well as direct burdens on the free exercise of rehgion be subjected to strict scrutiny. See id. As I argue below in section M.B, the Act leaves open many difficult issues. 
Throughout Part II, I attempt to reconcile the constitutional theory of Part I - which treats all incidental burdens as potential infringements - with existing doctrine - which only takes notice of substantial burdens. I conclude Part II by sketching a view of incidental burdens implicit in the joint opinion in Planned Parenthood $v$. Casey. ${ }^{23}$ That opinion suggests - rightly in iny view — that, in assessing the impact of an incidental burden on a right, the nature of the right may matter as inuch as the nature of the burden. To use a free speech example, whether a law forbidding sleeping in a park ${ }^{24}$ places a substantial burden on the right to express a view about hoinelessness ultimately depends on the extent to which the right to free speech guarantees the ability to make one's point in the particular way that one deeins most effective - and that is ultimately a question about the scope of the free speech right.

Part III addresses several questions left unanswered by the doctrinal exegesis im Part II. It begins by challenging the conventional division of burdens into the two categories of direct and imcidental. Although constitutional law usually places a premium on the distinction between laws that single out protected conduct for regulation and laws that do not, this distinction is incoinplete. Within the category of laws targeted at protected conduct, government soinetimes acts with the purpose of frustrating the exercise of a right. At other times, governinent merely addresses a problem associated with the exercise of a right without taking a hostile stance toward the right. Many such targeted regulations inay facilitate the right's exercise, in the way that a hicensing scheme may facilitate the exercise of the marriage right or the right to hold a parade. In general, laws having the purpose of frustrating the exercise of a right pose greater dangers than either facilitative targeted regulations or incidental burdens arising out of neutral laws. Hence, I conclude that the substantiality threshold ought to apply to incidental and facilitative direct burdens, but not to purposeful ones.

I also posit an important exception to this general proposition. Because some rights embody equality norms, the very act of singhing out persons who exercise such a right may constitute purposeful frustration of the right to equal treatment. The category of rights that embodies equality norms is quite broad and includes the general guarantee of equal protection as well as some aspects of the free speech principle (the governinent must be neutral with respect to coinpeting viewpoints) and the free exercise primciple (the government must be neutral with respect to religion). Laws that violate such

23505 U.S. 833 (1992).

24 See Clark v. Community for Creative Non-Violence, 468 U.S. 288, 289 (1984) (holding that the First Amendment does not protect participants in political protests from the enforcement of generally applicable park service regulations against camping). 
equality norms ouglit to trigger heightened scrutiny, even if they only impose minimal burdens.

Part III then discusses some imphications and limitations of the view advanced. It considers the relation between incidental burdens and facial challenges. These two categories together account for most of the cases in which a person may claim that the government has violated her primary conduct rights, and in some sense, they inirror one another: an imcidental burden involves an assertedly unconstitutional application of an otherwise constitutional law, whereas a facial challenge involves a purportedly unconstitutional law applied to one whose conduct lacks constitutional protection. I argue that, despite some superficial inconsistency, the proper approach to incidental burdens is consistent with the proper approach to facial challenges. Part III next outhines some of the questions that will likely arise in determining what constitutes a substantial burden on a right, including the question whether the distinction between positive and negative rights provides a principled basis for avoiding the floodgates problem. Finally, I suggest some implications of my approach for constitutional rights other than the ones specifically addressed in Part II.

The main thesis of this Article is both descriptive and normative. I contend throughout the Article that, to a large extent, existing law treats substantial incidental burdens as problematic and largely ignores other incidental burdens. I also argue that this is appropriate. Yet there exists a significant gap between the law and the law as I argue that it should be. The substantiality threshold is only implicit in the law and is not uniformly followed. Courts will be better able to assess the constitutionality of incidental burdens if they exphicitly recognize what makes such burdens problematic.

\section{Why Incidental Burdens Matter}

One could construct a model of fundamental rights that only protects rightholders against direct burdens. On this account, a right to $x$ is defined as a right not to be singled out for adverse government action on the basis of $x$. Such a view is conceptually coherent and would serve several practical purposes.

As the free speech examples quoted earher indicate, ${ }^{25}$ recoguizing incidental burdens as rights infringements could result in judicial scrutiny of all government regulation. Thus, some limiting principle is necessary. Ignoring mcidental burdens entirely provides such a principle and, because of its absolute character, avoids difficult hine-drawing problems.

Moreover, at least on average, direct burdens pose a greater danger to individual rights than do incidental burdens. A law imposing a di- 
rect burden will often serve some interest in preventing people from exercising their rights. Such an interest will ordinarily be illegitimate. In contrast, a law imposing an incidental burden will ordinarily serve independently important, rights-neutral government interests - the very interests that the law advances in cases in which it does not infringe rights. ${ }^{26}$ In addition; within the category of laws imposing direct burdens, many laws will have the very purpose of frustrating (as opposed to merely regulating) the exercise of a right. Such purposeful burdens could be deemed worse than incidental burdens because the illicit governinent purpose of infringing a right in some sense transforms the nature of the harm - in much the same way that a private party's illicit motive may render soine class of conduct more harmful than it would be absent the illicit motive. ${ }^{27}$

The Supreme Court's equal protection jurisprudence provides a helpful analogy. Only purposeful discrimination-is proscribed; government action that merely has a disparate racial impact does not violate the Clause.28 Indeed, we can carry the analogy one step further. Equal protection law does not distinguish between laws that facially einploy a suspect classification for illicit or legitimate reasons; instead, it subjects both categories to strict scrutiny. ${ }^{29}$ The Court justifies parallel treatment of these categories partly on the ground that it is difficult to distimguish between permissible and impermissible motives in the absence of strict scrutiny. ${ }^{30}$ Sinilarly, we might say that the difficulty of distinguishing between laws that purposefully frustrate rights and laws that target rights for some other (benign) purpose justifies

26 See Brown v. Borough of Mahaffey, 35 F.3d 846, 849-50 (3d Cir. 1994) (making this point with respect to free exercise of religion); cf. Stone, supra note II, at IO7 ("[O]ne might argue that because laws that have only an incidental effect on free speech are not aimed at speech, but restrict a broader class of activities, they are likely to rest on more substantial justifications than do laws that expressly restrict communicative activities."

27 See, e.g., Wisconsin v. Mitchell, Ir3 S. Ct. 2I94, 2 Ig6 (I993) (upholding sentence enhancement for battery based on racist motive). I have borrowed the notion that illicit purpose may qualitatively change the nature of the harm from Sherry Colb's forthcoming article. See Sherry F. Colb, Innocence, Privacy, and Targeting in Fourth Amendment Jurisprudence, 96 Colum. L. REv. (forthcoming 1996); see also Laurence H. Tribe, The Mystery of Motive, Private and Public: Some Notes Inspired by the Problems of Hate Crime and Animal Sacrifice, I993 Sup. CT. REv. I, 8 ("Properly drafted hate crime laws do not punish conduct because of what it expresses or reveals about the defendant's belief system but because of the harms it causes.").

28 See, e.g., Washington v. Davis, 426 U.S. 229, 238-39 (1976). As I argue below, however, the Court's requirement of purposeful discrimination arises out of its understanding of the Equal Protection Clause's substance rather than a more general view of incidental burdens. See infra section III.D.

29 See Adarand Constructors, Inc. v. Pena, I15 S. Ct. 2097, 2II2-I3 (I995); City of Richmond v. J.A. Croson Co., 488 U.S. 469,493 (I989) (O'Connor, J.) (plurality opinion).

30 See Adarand, II5 S. Ct. at 2 I I2-I3 (quoting Croson, 488 U.S. at 493 (O'Connor, J.) (plurality opinion)). 
treating all direct burdens as posing greater risks than do incidental burdens. $^{31}$

Finally, one might note that direct regulation of rights represents a kind of structural harm, in the same way that legislation inconsistent with the principle of separation of powers or beyond the powers enumerated in Article $I$ is harmful. ${ }^{32}$ These structural limitations serve the ultimate purpose of preserving liberty; 33 yet the Court views them as important in themselves, often enforcing them even absent an obvious threat to liberty in a particular case. ${ }^{34}$ Similarly, a government that punishes individuals because of their exercise of individual rights is, in this sense, harmful in itself quite apart from the harm it causes to the aggrieved individuals. ${ }^{35}$

At the very least, these arguments suggest that sound reasons can be advanced for taking direct burdens more seriously than incidental burdens. They do not show, however, that incidental burdens should never count as constitutional infringements. In order to answer the question whether the rights protected by the Constitution should receive any protection against incidental burdens, I now assess arguments based on constitutional text, history, and structure, as well as normative considerations. ${ }^{36}$

31 As I argue in section III.A, however, there remain good reasons to distinguish between laws that, on their face, target rights, and laws that - whether or not they target rights - have the purpose of infringing rights, just as one might make the judgment that there remain good reasons to distinguish between broadly remedial uses of race and invidious uses of race.

32 See generally Richard H. Pildes, Avoiding Balancing: The Role of Exclusionary Reasons in Constitutional Law, 45 HASTINGS L.J. 7 I I, 7 II-15 (1994) (using nineteenth-century constitutionalism as a model in which courts do not balance competing rights and interests but classify various governmental purposes as legitimate or illegitimate).

33 See, e.g., Youngstown Sheet \& Tube Co. v. Sawyer, 343 U.S. 579, 635 (1952) Uackson, J., concurring) ("TT]he Constitution diffuses power the better to secure liberty . . ...").

34 See, e.g., United States v. Lopez, II5 S. Ct. 1624, 1626 (I994) (invalidating a federal law prohibiting possession of a firearm in the vicinity of a school as beyond Congress's power under the Commerce Clause); Bowsher v. Synar, 478 U.S. 7I4, 734 (I986) (invalidating the GrammRudman-Hollings Act's reporting provisions because they vested executive functions in a congressional official). But see Mistretta v. United States, 488 U.S. 361, 390 (1989) (upholding the United States Sentencing Commission); Morrison v. Olson, 487 U.S. 654, 696-97 (1988) (upholding the position of independent counsel).

35 The Court's equal protection jurisprudence has in recent years tended toward this conception. In Shaw v. Reno, II3 S. Ct. 2816 (1993), for example, the harm "is, quite literally, the drawing of lines based on race." Dorf, supra note I, at $260 \mathrm{n} .93$ (discussing Shaw, II3 S. Ct. at 2824).

36 These sources are, of course, interconnected. See Fallon, supra note I7, at II93 (arguing that "the implicit norms of our constitutional practice call for a constitutional interpreter to assess and reassess the arguments in the various categories in an effort to understand each of the relevant factors as prescribing the same result'). Moreover, doctrine also plays a significant role in any constitutional discussion. Because of the complexity of the Supreme Court's doctrine, I defer discussing it until Part II. 


\section{A. Text}

Upon first reading, the constitutional text appears to say nothing about the question whether rights receive protection from incidental as well as direct burdens. Of the express provisions of the Bill of Rights, the text describes some in the language of a "right"37 or a "freedom,"38 whereas others receive protection by prohibitory language apphicable to the government. ${ }^{39}$ On the assumption that the various formulations may all be taken to protect rights, these observations only raise the key question: are these rights against anything inore than direct regulation? The word "right" does not compel an answer in either direction.

Nonetheless, although the text is not dispositive, some readings are more sensible than others. As Michael McConnell remarks with respect to the First Amendment's command that "Congress shall make no law ... prohibiting the free exercise" of religion, 40 the "more natural reading of the term 'prohibiting' is that it prevents the government from making a rehgious practice illegal," rather than merely preventing "the deliberate targeting of the prohibited activity."41 Along similar lines, we might say that granting protection for a "right to do $x$ " is an odd way to protect a "right not to be targeted for doing $x$." Thus, we can generalize McConnell's argument to apply to all primary conduct rights.

The strength of the textual argument may vary somewhat among different rights. For example, the First Amendment prohibits Congress from making any "law" establishing religion or abridging free exercise, free speech, or free press. As I have noted elsewhere, one could read this prohibition to direct our attention to the law rather than to the

37 See U.S. CoNST. amend. I "right of the people peaceably to assemble, and to petition the Government for a redress of grievances"); $i d$. amend. III ("right of the people to keep and bear Arms"); id. amend. IV ("right of the people to be secure in their persons, houses, papers, and effects, against unreasonable searches and seizures"); id. amend. VI ("right [of the accused] to a speedy and public trial, by an impartial jury of the State and district wherein the crime shall have been committed, .... and to be informed of the nature and cause of the accusation; to be confronted with the witnesses against him; to have compulsory process for obtaining witnesses in his favor, and to have the Assistance of Counsel"); id. amend. VII ("right of trial by jury"); id. amend. IX ("enumeration in the Constitution, of certain rights, shall not be construed to deny or disparage others retained by the people").

38 See id. amend. I (establishing "freedom of speech, or of the press" and "free exercise" of religion).

39 See id. (preventing government from "prohibiting the free exercise" of rehgion "or abridging the freedom of speech, or of the press"); id. amend. III ("No Soldier shall, in time of peace be quartered in any house, without the consent of the Owner, nor in time of war, but in a manner to be prescribed by law.'); id. amend. V (requiring a grand jury and prohibiting double jeopardy; compelled self-incrimination; deprivations of life, hberty, or property without due process; and takings of private property without just compensation); $i d$. amend. VIII (prohibiting excessive bail, excessive fines, and cruel and unusual punishment).

40 Id. amend. I.

41 McConnell, supra note I4, at III5. 
conduct prohibited by a particular application..$^{42}$ One way to understand this command would be to discount incidental burdens, because an incidental burden arises out of an application of the law rather than out of the law itself.43 This argument suggests that the First Amendment is unusual in not protecting conduct against incidental burdens, because other provisions of the Bill of Rights do not focus on the law im question. ${ }^{44}$ This would be a remarkable conclusion to draw from such slim textual evidence, however, especially in light of the central place that First Amendment rights occupy im our constitutional culture. ${ }^{45}$ Thus, although one could logically reconcile a jurisprudence that only recognizes direct burdens with the constitutional text, the more natural reading countenances the recognition of incidental burdens as well.

\section{B. History and Structure}

Turning from text to history and structure, we find that the manner in which the Bill of Rights became part of the Constitution sheds light on the nature of the rights protected by the Constitution. The Constitution proposed by the 1787 Convention and ratified by the states contamed no bill of rights. To be sure, it included a number of limitations on the powers of the federal government, ${ }^{46}$ but as the Federahists argued, the primary protection for individual rights was the fact that the federal government could only exercise the enumerated

42 See Dorf, supra note $I$, at 248.

43 However, the fact that the First Amendment directs our attention to the challenged law in any given case does not necessarily mean that, in determining whether the law is constitutional, we should ignore its applications. See id. at 261-64 (discussing First Amendment overbreadth doctrine).

$44 \mathrm{McC}$ Connell argues that the First Amendment is a better candidate for recognizing incidental burdens than are other constitutional provisions, because unlike the Fourth Amendment, which only proscribes "unreasonable" searches and seizures, the First Amendment "is expressed in abso-

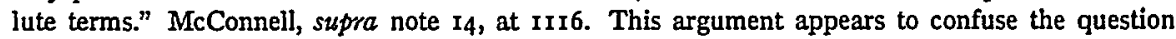
of how much protection a right receives against infringements - does the right prevent all interference or only unreasonable interference? - with the question of what counts as an infringement.

45 See Richard H. Fallon, Jr., Making Sense of Overbreadth, IOO XALE L.J. 853, 884 n.192 (I99I) ("The First Amendment, more even than other constitutional provisions conferring fundamental rights, contributes vitally to the preservation of an open, democratic political regime, at the same time as it secures rights of high importance to particular individuals.").

46 See U.S. CoNST. art. I, § 9. Federalists such as Alexander Hamilton pointed to these prohibitions to support the claim that the original Constitution did contain a kind of bill of rights. See The Federalist No. 84, at 5 r3-I5 (Alexander Hamilton) (Clinton Rossiter ed., 196r). As Anti-Federalists noted, however, the inclusion of some prohibitory language undermined the Federalists' claim that a bill of rights was unnecessary. See Brutus, Essay of November $x, r_{787}$, reprinted in The ORIGINS OF THE AMERICAN Constitution 313, 3 I7 (Michael Kammen ed., 1986). 
powers - none of which expressly authorized the violation of individual rights. ${ }^{47}$

One of the chief criticisms of those who opposed ratification of the original document was the absence of a bill of rights. ${ }^{48}$ "[T]n order to gain acceptance of their handiwork, the Federalists had to commit themselves, unofficially, to the formulation of a bill of rights when the first Congress inet in I789, even though many Federalists felt that such a list of protections was superfluous."49 However, the fact that the Constitution was ratified only with the understanding that a bill of rights would be added ${ }^{50}$ represented a resounding rejection of the Federalists' position. Among other things, the ratification deal signified a

47 See, e.g., Letter from James Madison to Thomas Jefferson (Oct. 17, 1788), in THE OrIGINS OF THE AMERICAN Constitution, supra note 46, at 367, 369 (expressing Madison's view that the omission of a Bill of Rights was unimportant because, among other things, "the rights in question are reserved by the manner in which the federal powers are granted"); James Wilson, Speech at a Public Meeting in Philadelphia (Oct. 6, r787), in Federalists AND ANTIFEderalISTS: The Debate over the Ratification of the Constitution 166 , I67 (John P. Kaminski \& Richard Leffler eds., 1989) [hereinafter FEDERALISTS AND ANTIFEDERALISTS] ("I]t would have been superfluous and absurd to have stipulated with a federal body of our own creation, that we should enjoy those privileges, of which we are not divested either by the intention or the act, that has brought that body into existence.").

48 See, e.g., George Mason, Objections to the Constitution of Government Formed by the Convention, reprinted in THE ORIGINS OF THE AMERICAN CONSTITUTION, supra note 46, at 255, 255; Letters from the Federal Farmer (II) (Oct. 9, 1787), reprinted in THE ORIGINS OF THE AMERICAN Constitution, supra note 46, at 270, 272; Letter from Richard Henry Lee to Governor Edmund Randolph (Oct. 16, r787), in FEDERALISTS AND ANTIFEDERALISTS, supra note 47, at 152, 154. For an instructive, if brief, account of the disagreement over the need for a bill of rights, see Gordon S. Wood, The Creation of the American Republic: 1776-1787, at 536-43 (1969).

49 Michael Kammen, Introduction to The ORIGINS OF THE AMERICAN CONSTITUTION, supra note 46 , at vii, xix. The Federalists initially opposed the inclusion of a bill of rights on other grounds as well. They argued that inclusion of a bill of rights would be taken to imply the existence of affirmative powers not otherwise delegated to the federal government. As Alexander Hamilton put it, a bill of rights "would contain various exceptions to powers which are not granted; and, on this very account, would afford a colorable pretext to claim more than were granted." The FederalisT No. 84, at 513 (Alexander Hamilton) (Clinton Rossiter ed., rg6r). The Federalists also maintained that the enumeration of specific rights would give rise to an inference that there were not other, unenumerated rights. See Randy E. Barnett, Reconceiving the Ninth Amendment, 74 CoRnell L. REV. I, Io (I988) ("The Federalists disparaged the idea of using a written declaration of rights in the Constitution precisely to protect the rights retained by the people."). In addition, the Federalists opposed a bill of rights on the grounds of political theory; to them, a bill of rights made sense only in the context of a compact between the sovereign and the people, but because the people were sovereign under the Constitution, a bill of rights would be a non sequitur. See Edmund S. Morgan, Inventing the People: The Rise of POPULAR SOVEREIGNTY IN ENGLAND AND AMERICA 282-83 (I988).

50 Massachusetts became the sixth state to ratify the Constitution when the convention agreed to a compromise proposed by John Hancock that involved ratification with recommendatory amendments. See Michael A. Gillespie, Massachusetts: Creating Consensus, in RATIFYING THE Constitution I38, r54-58 (Michael A. Gillespie \& Michael Lienesch eds., I989). Roughly the same compromise occurred in New Hampshire, the critical ninth state to ratify. See Jean Yarbrough, New Hampshire Puritanism and the Moral Foundations of America, in RATIFYING THE Constitution, supra, at $235,250-51$. The expectation of amendments was thus in place when Virginia and New York - two states without which the Union would not have been viable - 
prevailing belief that, absent a constitutional bill of riglits, a government with no express power to mfringe rights could nonetheless do so through the otherwise proper exercise of a rights-neutral power.

The Framers' generation understood this to be what the bill of rights debate was about. ${ }^{51}$ The leading Anti-Federalists described a bill of rights as setting "limits"52 or erecting "barriers"53 against governinent excesses. These metapliors are instructive. They suggest that riglits are walled-off enclaves into which the affirmative powers of government would extend were it not for the protection of a bill of rights. Importantly, the Federalists did not argue in response that riglits are not limits or barriers; they argued instead that the limited grant of delegated powers would not create a risk of powers extending into the protected zone of individual rights. They accepted that a bill of rights, if one were to be added, would erect barriers to the exercise of delegated powers - albeit unnecessary and dangerously suggestive ones. ${ }^{54}$

It should be understood that my historical/structural argument proceeds at a fairly high level of generality. Because of the inevitable manipulability of historical description, any argument that a legal text lias a particular meaning as a consequence of certain historical events sliould be met with skepticism. ${ }^{55}$ In my view, it would be nearly impossible to estabhish that the Constitution protects rights against inci-

voted on ratification. See John P. Kaminski, The Constitution Without a Bill of Rights, in THE Bill of Rights and the States 16, 33-39 (Patrick T. Conley \& John P. Kaminski eds,, r992).

51 I do not mean to suggest that this issue was all that was at stake in the debate over whether the absence of a bill of rights rendered the 1787 Constitution flawed. As Akhil Amar has noted, the Bill of Rights (as ratified, but especially as originally proposed) contained a number of structural provisions that responded as much to fears of federal intrusion into state prerogatives as to fears of federal infringements of individual rights. See Akhil R. Amar, The Bill of Rights as a Constitution, 100 YALE L.J. Ir3r, Ir37-38 (r99r) (describing the eighteenth-century conception of the Bill of Rights as primarily structural). But it is easy to overstate this point. Anti-Federalists who initially sought a bill of rights to protect state sovereignty settled for one that focuses its protection on individual liberty. See Michael Lienesch, North Carolina: Preserving Rights, in RATIFYING THE CONSTITUTION, supre note 50, at 343,343-65 (discussing how, during the course of the ratification debate in North Carolina, Anti-Federalists gradually adopted the individualcentered conception of rights held by Federalists). In any event, for present purposes it is not especially important whether the Bill of Rights originally responded more to structural or individual concerns. At the very least, important portions of the Bill of Rights protect and were originally understood to protect individual liberty; for these portions, the Framers and ratifiers of the Constitution and the Bill of Rights chose to protect liberty by juxtaposing powers and rights.

52 See Letters from the Federal Farmer (II), supra note 48, at 272.

53 See Brutus, supro note 46 , at 315 .

54 See supra note 49 and accompanying text.

55 See laurence H. Tribe \& Mrchael C. Dorf, On Reading the Constitution 98-ior (rggr) (illustrating the indeterminacy of historical argument by asking whether the Establishment Clause of the First Amendment embodies a deeply rooted tradition of separation of church and state); Michael C. Dorf, A Nonoriginalist Perspective on the Lessons of History, r9 HARV. J.L. \& PUB. POL'Y 35I, 360 (1996) (arguing that, even when consensus exists concerning the historical facts, the interpretation of history is a normative enterprise). 
dental as well as targeted burdens because certain key persons or communities held this position at some important time. Were this my claim here, I would have to argue, among other things, that the relevant actors' views broadly reflected those of the relevant pohtical community and that they enacted those views into law. However, the historical argument that I am making here is of a different character.

The point is not that the adoption of the Bill of Rights confirmed a particular view about mcidental burdens. The leading proponents of a bill of rights did not address such detailed questions as the distinction between direct and incidental burdens, both because they had larger issues to confront and because the very concept of judicial protection of rights against legislative encroachment was in its nascency. ${ }^{56}$ Thus, I do not contend that the adoption of the Bill of Rights represented either a wholesale endorsement of all that its proponents (mostly AntiFederalists) believed or a rejection of what its opponents (mostly Federalists) believed. Instead, this brief historical discussion confirms that the relevant actors during the founding era understood that, but for the negative limits contained in the Bill of Riglits, the enumerated powers could logically have extended into the zone of protected rights.

As a consequence of the struggle over the Bill of Rights, the structure of the Constitution provides a substantial basis for considering incidental burdens as infringing riglits. Article I sets forth most of the affirmative powers of the federal government. Because the federal government is a government of enumerated powers, ${ }^{57}$ it may not take any action not authorized by an affirmative grant of power. But the fact that an affirmative power authorizes some governmental action does not necessarily guarantee its constitutionality. The Constitution also places negative hmits on the federal government's powers, ${ }^{58}$ and these negative limits typically take the form of individual rights. By juxtaposing affirmative powers with negative limits, the Constitution's architecture assumes that, even when the government pursues a permissible goal, the government might sometimes violate individual rights - and thus, the negative limits prohibit otherwise valid exercises of power. ${ }^{59}$ This structure strongly suggests protection against

56 For a discussion of the revolutionary era antecedents of judicial review and enforceable rights, see Bernard Bailyn, The IDEological Origins of the American Revolution I75-89 (enlarged ed. I992). For an account of the experience of the states under the Articles of Confederation that suggests growing acceptance of the practice of judicial review, see William $M$. Treanor, The Case of the Prisoners and the Origins of Judicial Review, I43 U. PA. L. Rev. 49r, 498-500 (1994).

57 See, e.g., United States v. Lopez, II5 S. Ct. 1624, 1626 (I995).

58 The Bill of Rights contains most such limits. Others are found in Article I of the Constitution. See, e.g; , U.S. CoNST. art. I, $\S 9$, cl. 2 (establishing that the privilege of habeas corpus shall not be suspended in peacetime); $i d$. art. I, $\S 9, \mathrm{cl} .3$ (prohibiting ex post facto laws).

59 Thus, my structural argument is of a piece with my historical argument. $C f$. H. Jefferson Powell, The Original Understanding of Original Intent, 98 HARv. L. REv. 885, 888 (1985) ("[T] he original intentionalism was in fact a form of structural interpretation.'). 
incidental burdens which, by definition, consist of burdens arising out of otherwise permissible exercises of government power.

I should be clear that my argument does not rest on the claim that the only purpose of the Bill of Rights is to protect against incidental burdens. That claim would be false, for even if one accepts that the proponents of the Bill of Rights wished to protect rights against encroachment by otherwise valid powers, a bill of rights strictly limited to protection against direct burdens would still liave value. Consider a hypothetical example based on the Supreme Court's Commerce Clause jurisprudence. The Court has lield that the Commerce Clause authorizes Congress to regulate commerce, even when the primary motive behind the legislation is not commercial. ${ }^{60}$ Thus, in the course of upholding congressional authority to prohibit racial discrimination of a private and commercial nature, the Court stated that "the determinative test of the exercise of power by the Congress under the Commerce Clause is simply whether the activity sought to be regulated is 'commerce which concerns more States than one' and has a real and substantial relation to the national interest," 61 adding that "Congress was not restricted by the fact that the particular obstruction to interstate commerce with which it was dealing was also deemed a moral and social wrong."62 Based on this principle, Congress could, pursuant to the Commerce Clause, prohibit the sale of bumper stickers criticizing the national government - assuming that automobiles exhibiting bumper stickers move among the states and that the messages that the stickers carry bear a substantial relation to the national interest. Of course, the statute would be unconstitutional under the First Amendment, but not as an imcidental burden; rather, the prohibition directly targets free speech. One might therefore conclude that the negative limits of the Bill of Rights serve an important purpose even if we ignore imcidental burdens; the negative limits ensure that, when Congress uses one of its affirmative powers for a collateral purpose (such as correcting a social wrong), it pursues only legitimate collateral purposes.

This example has some force, but it ultimately misconceives the historical/structural argument for treating incidental burdens as infrimging riglits. The argument does not purport to show that, absent recognition of mcidental burdens, there would be no poimt to negative rights. Were that the nature of the claim, then the bumper sticker example would refute it. However, the historical/structural argument aims to show that the best understanding of a document that juxtaposes affirmative powers and negative rights is one that recognizes that an otherwise generally proper exercise of power can, in specific

60 See Heart of Atlanta Motel, Inc. v. United States, 379 U.S. 24 I, 257 (I964).

61 Id. at 255 .

62 Id. at 257 . 
circumstances, infringe a right. The Constitution's architecture reveals a two-fold strategy for limiting government - first, by delegating only certain powers, and second, by checking valid exercises of those powers with individual rights. Although logically consistent with a vision of rights that only protects against direct burdens, the structure more comfortably fits with a broader role for individual rights.

Moreover, the bumper sticker counterexample is anachronistic. To be sure, modern commerce clause jurisprudence may permit Congress to further any purpose through the vehicle of regulating interstate commerce.63 But the Framers' generation no doubt had a narrower understanding of the scope of the Commerce Clause. As Lawrence Lessig notes, even the Marshall Court's broad readings of the Commerce Clause ${ }^{64}$ reflected the early understanding that the Article I powers themselves could not be used for illicit - that is, pretextual purposes. ${ }^{65}$ On this understanding, laws designed to suppress free speech in a commercial context would be imvalidated as pretextual uses of the Commerce Clause, ${ }^{66}$ even if there had been no First Amendinent. ${ }^{67}$

Thus, it may well be the case that, at the time of the adoption of the Bill of Rights, the principal effect of recognizing rights to primary conduct that blocked otherwise valid powers was to block incidental burdens. Most direct burdens would have been seen as pretextual uses of the enumerated powers and thus invahd on that independent ground.

Had the Constitution's meaning been permanently fixed in the eighteenth century, this point would conclude the historical/structural

63 On the other hand, it may not. Cf. United States v. Lopez, I15 S. Ct. 1624, 1630-3I (I995) (holding that the possession of a gun in the vicinity of a school is not economic activity that substantially affects interstate commerce).

64 See Gibbons v. Ogden, 22 U.S. (9 Wheat).I, 195-96 (1824) (affirming federal power to regulate intrastate shipping as encompassed within the power to regulate interstate shipping); McCulloch v. Maryland, I7 U.S. (4 Wheat) 3I6, 424 (I8I9) (upholding congressional power to charter the Bank of the United States).

65 See Lawrence Lessig, Understanding Changed Readings: Fidelity and Theory, 47 STAN. L. Rev. 395, 448 (I995); see also Henry P. Monaghan, Stare Decisis and Constitutional Adjudication, 88 CoLUm. L. REV. 723, 731-32 (1988) ("[I]t is beyond dispute that [the Framers'] generation did not believe that everything affected commerce in a constitutionally relevant sense.").

66 See Lessig, supra note 65, at $448 \&$ n.23r (discussing the power of the Supreme Court to invalidate laws passed "under the pretext of executing [Congress's] powers" (quoting $M c C u l l o c h$, I7 U.S. (4 Wheat.)) at 423 (internal quotation marks omitted)).

67 I do not mean to express confidence in the Court's abihty to distinguish between laws aimed at the commercial aspects of a transaction and those aimed at some other aspect. See Lopez, II5 S. Ct. at 1653-54 (Souter, J., dissenting) (comparing the majority's reservation of deferential review for regulations of commercial activity to the pre-1937 Court's effort to distinguish between direct and indirect regulations of comnierce). Nevertheless, earlier generations believed the distinction an important one, and for this reason, arguments based on congressional omnipotence are anachronistic to the extent that they purport to provide insight into the original understanding. 
discussion. But of course, important events transpired later. To summarize ruthlessly, two dramatic shifts occurred. First, in the wake of the Civil War, key negative limits were placed on state power, ${ }^{68}$ limits which have been imterpreted im the twentieth century to be roughly coextensive with those applicable to the federal government. ${ }^{69}$ Second, at least simce the I930s, the Supreme Court has acquiesced to congressional exercises of power nominally pursuant to the Commerce Clause - which have effectively converted the federal government from a government of delegated powers to one of nearly plenary power. ${ }^{70}$ Do these changes alter the historical lesson of the enactment of the Bill of Rights?

Concerning the extension of rights to actions taken by the states, it would be conceptually coherent to say that, as a matter of structure, there is still no state analogue to the federal juxtaposition of powers and rights. States do not derive their affirmative powers from the federal Constitution. Thus, for the states the negative limits are freestanding. One could, consistent with the text and structure of the Constitution, interpret rights against the states as not including rights against incidental burdens. But if, as modern constitutional law assumes, the Fourteenth Amendment applies (nearly all of) the rights agaimst the federal government to the states as well, then the more natural reading would give tlose rights the same scope whether applied against the states or the federal government - and that bas been the approach generally followed by the Supreme Court. ${ }^{71}$ The very arguments that lead the Court to conclude that a provision of the Bill of Rights is fundamental and therefore applicable to the states typically lead the Court to provide the same level of protection against

68 See U.S. CoNST. amend. XIV, § I "No State shall make or enforce any law which shall abridge the privileges or immumities of citizens of the United States; nor shall any State deprive any person of life, liberty, or property, without due process of law; nor deny to any person within its jurisdiction the equal protection of the laws.").

69 See TRIBE, supra note $5, \S I I-2$, at 772-74 (describing the process by which the Supreme Court "incorporated" most of the protections of the Bill of Rights into the Fourteenth Amendment's Due Process Clause).

70 See, e.g., Heart of Atlanta Motel, Inc. v. United States, 379 U.S. 24I, 26I (1964) (upholding congressional power under the Commerce Clause to prohibit racial discrimination by a motel serving interstate travelers); Wickard v. Filburn, 3 I7 U.S. III, I28-29 (I942) (upholding congressional power under the Commerce Clause to regulate a farmer's production of a small quantity of wheat for personal consumption or local sale); Umited States v. Darby, 3I2 U.S. 100, 115 (1941) (upholding congressional power under the Commerce Clause to prohibit interstate shipment of lumber produced by workers whose compensation violated the national minimum wage or maximum hour standards).

71 See, e.g., Mapp v. Ohio, 367 U.S. 643, 654-55 (1961); Cantwell v. Connecticut, 310 U.S. 296, 303 (I940); Fiske v. Kansas, 274 U.S. 380, 386-87 (I927). There are exceptions, however. For example, the Sixth Amendment guarantees a right to a unanimous jury verdict in all federal criminal trials but not in state criminal trials. See Johnson v. Louisiana, 406 U.S. 356, 369-7I (I972) (Powell, J., concurring) (stating that Justice Powell's concurrence also applies to the companion case of Apodaca v. Oregon, 406 U.S. 404 (1972)). 
both state and federal intrusions. ${ }^{72}$ If rights against the federal government include protection against incidental burdens, then the same should be true of rights against the states.

What can we say about the shift from a model of federal delegated powers to one of virtually plenary power? This change seeins to call into question the original basis for taking imcidental burdens seriously: the juxtaposition of powers and rights. If Article $I$ is read as simply an awkward way of granting plenary power, then the juxtaposition is less evident.

This argument is premised on what Laurence Tribe and I have elsewhere termed a "hyper-integrationist" fallacy. ${ }^{73}$ It assuines that the Constitution that we have now was created all at once in order to express a single idea. Yet the Framers and ratifiers never decided to juxtapose federal plenary power with enuinerated and unenumerated rights. Rather, in the early Republic, rights were protected by two inechanisms: the limited grant of Article I powers and the additional precaution of the Bill of Rights. As we have seen, the story of the enactment of these two kinds of protections suggests an interpretation of rights that protects against incidental as well as targeted burdens.

The question that we inust now ask is not how would we understand the scope of the rights protected by a constitution that granted virtually plenary power to Congress in the first instance. We have no such constitution. Instead, we must ask how the expansion of federal power accomphished in the twentieth century bears on the proper understanding of constitutional rights. To the extent that the expansion of power affects the scope of rights, it would appear to point toward strengthening rather than weakening the protection of rights. Assuming that protection against incidental burdens plays some normatively important role in our constitutional scheme (a question which I address in the next section of this Part), the expansion of federal power should produce greater protection against both incidental and direct burdens.

With the limits inherent in a governinent of delegated powers effectively gone, the principal protection for individual rights consists of negative limits. Thus, it is not surprismg that, since it abandoned a restrictive interpretation of the Commerce Clause, ${ }^{74}$ the Supreme

72 See TruBE, supra note 5 , § II-2, at 773 n.25.

73 See Tribe \& Dorf, supra note 55, at 24-30; see also I Bruce Ackerman, We the PeoPLE: Foundations 86-103 (rggr) (discussing a version of the same problem, which he terms "intergenerational synthesis").

74 See United States v. Darby, 312 U.S. roo, Ir5-I7 (I94) (overruling Hammer v. Dagenhart, 247 U.S. 25I, 277 (Igr8), which had invalidated Congress's prohibition of interstate shipment of goods produced by child labor). Although United States v. Lopez, II5 S. Ct. I624 (I995), invalidated a purported exercise of the commerce power, it expressly reaffirmed Darby and the other twentieth-century cases giving a broad interpretation to the Commerce Clause. See id. at I628-30. 
Court has continued to play an extremely active role im the protection of individual rights (albeit different rights from those that it protected during the heyday of laissez-faire). In short, the history of the postI789 period in no way undermines and, partly strengthens, the case for treating incidental burdens as infringements on constitutional rights. ${ }^{75}$

\section{Normative Considerations}

In addition to constitutional text, history, and structure, normative considerations $^{76}$ play an inportant role in fixing constitutional meaning. ${ }^{77}$ In other words, discussion of the question "What does the Con-

75 One recent event is unsettling because it may signal a departure from the conventional relation between powers and rights. The proposed Twenty-Eighth Amendment, which passed the House of Representatives in June of 1995, see Katharine Q. Seelye, House Easily Passes Amendment to Ban Desecration of Flag, N.Y. TrMes, June 29, I995, at Ar, provides: "The Congress and the States shall have the power to prohibit the physical desecration of the flag of the United States." Id. at A19. If one follows the ordinary approach to powers and rights, the Amendment has no effect. The fact that Congress has the affirmative power to prohibit flag desecration would not immunize its action from scrutiny under the Constitution's negative limits, including the First Amendment - just as the fact that the Commerce Clause authorizes the regulation of bumper stickers on cars moving in interstate commerce does not immunize the hypothetical nobumper-stickers-critical-of-the-government law from First Amendment scrutiny. Under Texas v. Johnson, 49 I U.S. 397 (I989), which held that a conviction for flag desecration under a Texas statute was inconsistent with the First Amendment, see id. at 420 , and under United States v. Eichman, 496 U.S. 3 I0 (1990), which reached the same conclusion with reference to Congress's Flag Protection Act, see id. at 312-13, 318-19, the laws authorized by the Twenty-Eighth Amendment would be prohibited by the First Amendment. And as to the states, the proposed TwentyEighth Amendment would appear to be completely unnecessary, because their police power already extends to flag desecration, although that power would be trumped by the First and Fourteenth Amendments.

Clearly, however, it would be incorrect to read the proposed Twenty-Eighth Amendment in the manner described above. The obvious purpose of the Amendment is to overrule Johnson and Eichman. Perhaps Congress would have done better to propose an amendment that read as follows: "Congress shall have the power to prohibit the physical desecration of the flag of the United States. The First Amendment to this Constitution shall not be construed to bimit this power or the power of the States to prohibit the physical desecration of the flag of the United States." The apparent departure in Congress's text from the ordinary interplay of powers and rights no doubt results from sloppy drafting rather than from a reevaluation of our constitutional scheme. Thus, although it would be inappropriate for the courts to interpret a duly ratified Twenty-Eighth Amendment as having no effect, it would also be wrong to treat it as signaliing a departure from the long-accepted relation of powers and rights.

$76 \mathrm{I}$ refer here to normative concerns derived mostly from sources external to constitutional text, structure, history, and doctrine. In Phihp Bobbitt's terminology, these concerns would include both "ethical" and "prudential" considerations. See BoBBITT, supra note 17 , at 12-13. To the extent that Bobbitt's terms imply a distinction between nonconsequentialist and consequentialist arguments, I locate both within the broader category of normative considerations.

77 Laurence Tribe has recently argued that, even when the constitutional text is ambiguous, interpreters may find sufficient guidance from constitutional structure and the historical circumstances of adoption to point clearly (if not utterly unambiguously) in one direction. See Laurence H. Tribe, Taking Text and Structure Seriously: Reflections on Free-Form Method in Constitutional Interpretation, I08 HARV. L. REv. 1223, 1278-79 (1995). By this measure, normative arguments may be unnecessary to establish that incidental burdens are real infringements of rights. 
stitution mean?" will be imformed by, and sometimes even collapse into, a discussion of the question "What should the Constitution mean?" Thus, when asking whether the Constitution protects rights against imcidental burdens, we should also ask whether the Constitution ought to protect rights against incidental burdens. I argue in this section that, whether one takes a deontological or a consequentiahist view, ${ }^{78}$ rights ought to be protected against imcidental burdens.

A deontological account of rights postulates that it is wrong to violate someone's rights, independent of both the harm to the rightholder and the benefit for society. As Ronald Dworkin explains, "[i]f someone has a right to solnething, then it is wrong for the government to deny it to him even though it would be in the general interest to do so."79 In other words, even though some actions would increase aggregate utihty, they are simply off limits because they transgress on individuals' inviolable interests. 80

Dworkin's view that rights serve as trumps inplies that a right protects against incidental as well as direct burdens. Consider an action by the federal government taken pursuant to soine delegated power. If in a particular case the otherwise valid prograin substantially interferes with the exercise of an individual's right, the question inevitably arises whether the power or the right prevails. The concept of a trump held by the rightholder gives the answer: the very idea that a right is a trump ineans that it prevails even when the government is

However, readers who are uneasy with Tribe's implicit suggestion that there is a hierarchy of constitutional meaning - text trumps structure trumps history trumps normative arguments may wish to consider all sources of constitutional meaning, including normative ones, before deciding any issue.

78 I do not mean to claim that this dichotomy fully captures all possible accounts of rights. For instance, one could classify political theories as goal-based, right-based, and duty-based. See J.L. Mackie, Can There Be a Right-Based Moral Theory?, in THEORIES OF RIGHTS, supra note 8, at 168 , I68 (attributing the division to RONALD DwORKIN, TAKING RIGHTS SERIOUSLY I7 I-72 (I977)). More radically, one could classify rights as neither consequentialist nor deontological. See, e.g., Lloyd L. WeinReB, Oedipus at Fenway PARK 32 (I994) ("[R]ights trump both the right and the good."). I include both right-based and duty-based theories within the deontological category, because under either theory, consequentialist arguments do not justify a right. A rightbased theory begins with rights, and for a duty-based theory, rights arise as correlates of duties without an intervening consequentialist assessment.

79 Ronald DWORkIN, TAKING Rights SeRIOUSLy 269 (1977).

80 Moral philosophers have developed something of a cottage industry in devising examples that make this point. See, e.g., Gewirth, supra note 8, at 9I \& n.I (listing and describing several sources). My personal favorite is found in Judith J. Thomson, The Trolley Problem, 94 YALE L.J. I395 (I985). Thomson asks whether a doctor who has five patients in need of transplants may kill one perfectly healthy patient to liarvest her organs. See id. at 1396 (attributing this hypothetical question to Philippa Foot, The Problem of Abortion and the Doctrine of the Double Effect, 5 OXFORD ReV. 5, II-I3 (1967), reprinted in PHIIPPA FOOT, ViRTUES AND VICES AND OTHER ESSAYS IN MORAL PHILOSOPHY I9, 24, 27-29 (I978)). The operations would increase aggregate utility, but the actions are nonetheless morally wrong on the deontological ground that they violate the healthy patient's rights. 
pursuing an otherwise important interest. The right is prior to the good. ${ }^{81}$

One might argue that treating rights as trumps is unrealistic. When push comes to shove, almost no one would seriously contend that rights always trump powers. Given the choice between, say, pursuing the utility-maximizing course of preventing a nuclear holocaust versus protecting the freedom of the press by allowing publication of the secret of the hydrogen bomb, it would seein appropriate for the government interest to trump the right rather than vice versa. ${ }^{82}$

The considerable force of such an example has led some rightstheorists and courts to reject the concept of absolute rights. ${ }^{83}$ For instance, Frederick Schauer depicts rights not as trumps but as shields. ${ }^{84}$ This shield metaphor better characterizes existing Supreme Court doctrine than does the concept of a truinp. A right as a shield may be overcome by a sufficiently coinpelling interest if the restriction on the right is narrowly tailored to the compelling interest. ${ }^{85}$ In Schauer's scheme, we might say that the right shields the rightholder from infringements on behalf of all but the strongest governmental interests.

The move from absolute to qualified rights does not undermine the case for taking incidental burdens seriously. The shift merely reduces the degree of protection that rights receive. The metaphor of a shield, like that of a barrier discussed during the debate over ratification of the Constitution, ${ }^{86}$ implies protection against all manner of infringements. A government interest may soinetimes overcome a shield but not a trump because a shield's strength is finite whereas a trump's strength is infinite; however, the strength of the barrier has no bearing on the question whether the barrier protects against stray as well as direct attacks. ${ }^{87}$

81 As the play on words illustrates, I mean to associate rights as trumps rather strongly with deontological accounts of justice. One could of course construct a model of rights in which only direct burdens trigger the trump. Although such a model would be conceptually coherent, it would not be the conventional description of rights as trumps. Moreover, this model would be awkward. The nature of a trump implies that the interests of the trumpholder should initially be considered independently of the government's justification for its action.

82 See United States v. Progressive, Inc., 467 F. Supp. 990, 999-1000 (W.D. Wis. 1979) (issuing a preliminary injunction against publication of an article entitled "The H-Bomb Secret: How We Got It, Why We're Telling It"). But see TRIBE, supra note 5 , \$ 12-36, at 1053-54 (criticizing the Progressive decision because the censored information was unclassified and might well have led to an informed political debate, which would have reduced the risk of nuclear war).

83 See, e.g., TRIBE, supra note 5, $\$ \mathrm{I2-2}$, at 792 n.I9 (listing some representative literature in the academic debate about whether speech rights are absolute).

84 See Schauer, supra note 8, at 428-3I.

85 See id. at 430 . For one example, consult Austin v. Michigan State Chamber of Commerce, 494 U.S. 652 (I990), which held that a state campaign finance law that prohibits corporations from using corporate funds for independent expenditures in support of or in opposition to candidates running in state elections satisfies strict scrutiny. See id. at 655 .

86 See supra notes $51-54$ and accompanying text.

87 See supra note 44 . 
One difficulty with the metaphorical shift from rights as trumps to rights as shields involves the imtellectual coherence of the resulting conception. As I noted above, the vision of rights as trumps is nonconsequentialist. But if rights bar government actions despite diminutions in overall utility, how can we make sense of a compelling interest justifying the overriding of a right? In otler words, is a right as a shield compatible with a conception of deontological rights?

This quandary of moral philosophy questions the consistency of the deontological view of rights and the existing constitutional order. Whether one can explain or defend that order on nonconsequentialist grounds is beyond the scope of this Article. ${ }^{88}$ I would suggest that such an explanation - if it exists - also advances the case for taking mcidental burdens seriously. Even if the existing constitutional order rests on a consequentialist approach to rights, ${ }^{89}$ however, incidental burdens still ought to inatter.

According to a consequentialist account, people have individual rights because of a judgment that some goal - such as aggregate happiness or utility - will be best served in the long run by recognizing rights as a matter of positive law. John Stuart Mill gave the most famous such account of rights. He defended libertarian principles as ultimately based on utihtarian ones, stating, "I forgo any advantage

88 The nonconsequentialist could defend her view of rights on two grounds. First, she could argue that true rights are absolute and therefore that no consequences are sufficiently disastrous to justify overriding them. See, e.g., Gewirth, supra note 8, at I08 (giving the example of "[t]he right not to be made the intended victim of a homicidal project"). Second, the nonconsequentialist could retreat to abstraction, arguing for example, that the only true rights are rights to dignity and to political equality. Cf. DwORKIN, supra note 78 , at $198-99$ (stating that "[a]nyone who professes to take rights seriously" must recognize the ideas of "human dignity" and "political equality"). For the abstractionist, specific instances of the government overriding more particular rights would not count as real infringements because the overriding does not violate dignity and equality.

Whatever their other merits, neither of these defenses appears to be compatible with our constitutional practice. First, notwithstanding occasional protestations to the contrary by individual Supreme Court Justices, see, e.g., Ginzburg v. United States, 383 U.S. 463, 48x (Ig66) (Black, J., dissenting) (" $\mathrm{I}$ think the First Amendment forbids any kind or type or nature of governmental censorship over views as distinguished from conduct."), constitutional rights may sonetimes be justifiably overridden under long-accepted practice. Second, the rights protected by the Constitution are often specified at a more particular level than "dignity" and "equality." But see U.S. CONST, amend. IV (prohibiting "unreasonable searches and seizures"); id. amend. XIV, $\S$ (guaranteeing "equal protection of the laws").

89 To the extent that the Framers and ratifiers of the Constitution accepted the existence of "natural rights" endowed by God and reflected in English common law by happy coincidence, see BAIl YN, supra note 56 , at 76-79; WoOD, supra note 48 , at $260-65$, they preferred to view rights in nonconsequentialist terms. Thus, with respect to questions that in some way turn upon the choice between a consequentialist and nonconsequentialist approach, the Framers' intent, so far as it is relevant, apparently favors the latter. 
which could be derived . . . from the idea of abstract right, as a thing independent of utility."

One might take the view that, although rights are justified on consequentialist grounds, no consequentialist argument should suffice to override a right in any individual case. In practice, this approach would be indistinguishable from the nonconsequentialist view. ${ }^{91}$ Alternatively, a consequentialist might believe that the ultimate political goal (for example, maximum utihty) will be best served if rights only act as presumptive limits - that is, as shields. In either case, the right derives from a consequentialist calculus.

Virtually any consequentialist account of rights will recognize that at least some incidental burdens ought to be treated as infringements. A consequentialist will typically wish to protect a right as a means of advancing some interest of importance to the rightholder. If people will have greater utility if they are able to do $x$, then the consequentialist will affirmatively value the right to do $x$, not merely the right to be free from regulation on account of doing $x$. A law of general applicability that mcidentally burdens a person's right to do $x$ denies that person the utility that she would otherwise derive from doing $x .92$ In short, incidental burdens will matter to the consequentialist.

Whether one conceives of rights as prepolitical entitlements or as positive enactments designed to advance some conception of the good, they ought to have protection against imcidental as well as targeted burdens. Thus, normative considerations support the same inference as the one gleaned from constitutional text, history, and structure. Because the Constitution appears to protect against infringement of rights by imcidental burdens, one must now confront the practical

90 John S. Mrll, ON Liberty (1859), reprinted in JohN S. Mill, Three EsSAys I, I6 (1975). Mill's critics portray On Liberty "as a moving rhetorical document, the philosophical significance of which consists of the nonutilitarian insights illegitimately smuggled in by Mill," FRED R. Berger, happiness, Justice, and Freedom: The Moral and Political Philosophy of John STUART Mill 227 (1984), a conclusion that Berger contests, see id. at 226-78.

91 See 1 ACKerman, supra note 73, at 12 (advancing a conception of American constitutionalism, founded ultimately on consensus, that nonetheless "allows an important place for . . . 'rights as trumps," because they are placed beyond the realm of ordinary politics by constitutional politics); DwORkIN, supra note 78, at 199 n.I (stating that "this sort of 'institutional' utilitarianism" is consistent with his general approach "because it argues that we must treat violations of dignity and equality as special moral crimes, beyond the reach of ordinary utilitarian justification").

92 One could also invoke this reasoning to argue that a right to $x$ entails a right to a government subsidy for $x$ or a right to $x$ that is enforceable against private actors, because from the perspective of the rightholder, it matters little whether the government or her impecuniousness prevents her from exercising the right. Resistance to recognizing positive rights and rights against private actors, however, should not translate into resistance to treating incidental burdens as infringements. Two concerns typically motivate the law's failure to recognize positive rights and rights against private actors. First, the courts may lack the institutional competence to engage in the wholesale redistribution that government subsidization requires. Second, a constitution should only specify the powers of and limits on government, not private actors. Incidental burdens no more strongly implicate these concerns than do direct burdens. 
problem of how to recognize incidental burdens without invalidating all legislation - that is, the floodgates concern. As I discuss in the next section, current Supreme Court doctrime attempts to reconcile these theoretical and practical considerations by treating imcidental burdens as imfringements on constitutional rights in some, but not all, circumstances.

\section{CURRENT DOCTRINE}

Before examining how the Supreme Court has treated imcidental burdens, it will be useful to sketch the universe of possible approaches. There are at least six primary ways of approaching incidental burdens. First, the Court could treat all incidental burdens in the same manner as it treats direct burdens on fundamental rights - that is, the Court could apply strict scrutiny. Second, the Court could subject all incidental burdens to some form of heightened scrutiny that is less stringent than the standard apphicable to direct burdens. Third, the law could recognize only some imcidental burdens as imfringements of constitutional rights and treat these burdens in the same manner as it treats direct burdens, but ignore other incidental burdens. Fourth, the Court could recognize only some incidental burdens as imfringements of constitutional rights and subject them to some form of heightened scrutiny that is less stringent than the standard applicable to direct burdens. Fifth, the law could entirely ignore incidental burdens for constitutional purposes. Sixth, the law could treat imcidental burdens in a completely ad hoc or intuitionist manner, responding to the facts of each case absent any rule-based doctrime. ${ }^{93}$

The third and fourth approaches represent the best options for a general doctrine. The first two approaches would jeopardize government's abihty to function, because they would require judicial scrutiny, if not judicial imvalidation, of nearly all government regulation. ${ }^{94}$ Unless one cannot find any principled distinctions among types of incidental burdens, the fifth approach would appear unnecessarily drastic. The sixth approach may have much to recommend it - and, no doubt, much constitutional law is ad hoc - but this method, by definition, cannot undergird a general doctrine. Ad hoc balancing would seem to be a fallback, rather than a starting, position. Thus, only the

93 A variant of the sixth possibility would be to apply distinct rules to incidental burdens on different rights.

94 See, e.g., Frederick Schauer, Cuban Cigars, Cuban Books, and the Problem of Incidental Restrictions on Communications, 26 WM. \& MARY L. REV. 779, 784 (I985) ("To be concerned significantly, in a constitutional sense, with incidental effects is to be committed to judicial scrutiny of an enormous range of government decisions."); Stone, supra note II, at I05. 
third and fourth options offer a reasonably complete doctrine that treats incidental burdens seriously without crippling government.95

The choice between approach three and approach four is a choice between strict scrutiny and something akin to intermediate scrutiny. Although that decision can be important, ${ }^{96} \mathrm{I}$ focus on the similarities of these two approaches rather than on their differences. Under either option, the most difficult issue will be distinguishing those incidental burdens that trigger some level of heightened judicial scrutiny from those that trigger none. ${ }^{97}$ Consideration of the Supreme Court's linedrawing efforts in this area illustrates the difficulty in making this distinction.

Analysis of the Court's treatment of mcidental burdens is coinplicated by the fact that no unified constitutional doctrine of imcidental burdens currently exists. Instead, the Supreme Court has generally confined its assessment of incidental burdens on a particular right to the jurisprudence involving only that right. In the following sections of this Part, I describe and critique the Court's treatment of incidental burdens in three areas: free speech, free exercise of religion, and the unenumerated rigbt to privacy. Despite tbe Court's fragmented approach, I focus as much on the often overlooked similarities posed by mcidental burdens arising in these areas as on the differences.

\section{A. Incidental Burdens on Speech}

Both the case law and the academic treatment of incidental burdens on free speech are enormous, and I do not attempt anything like a comprehensive summary here. ${ }^{98}$ At the risk of vastly oversimplifying, much free speech doctrime depends on whether a challenged regu-

95 In distinguishing between ad hoc balancing and heightened scrutiny, I do not intend to suggest that the application of heightened scrutiny involves no balancing. I agree with Stephen Gottlieb that "[s]trict scrutiny is a form of balancing with a rigorous burden of proof placed on government." Stephen E. Gottlieb, Compelling Governmental Interests and Constitutional Discourse, 55 ALB. L. REv. 549, 55I (1992). But see Kathleen M. Sullivan, Governmental Interests and Unconstitutional Conditions Law: A Case Study in Categorization and Balancing, 55 ALB. L. REV. 605, 606 (1992) (contending that, in practice, rational basis review and strict scrutiny represent categorical rather than balancing approaches, whereas only "[i]ntermediate scrutiny is real balancing"). In the present context, the important question is whether a rightholder must make some threshold showing before a court will undertake administratively costly review.

96 See infra pp. 1202-04.

97 See Schauer, supra note 94 , at 790-9I (noting the "floodgates" problem for those who would recognize "exceptions" to what Schauer perceives to be the current practice whereby the law usually ignores incidental burdens).

98 For a small sample of the excellent commentary on incidental burdens in the free speech area, consult TRIBE, cited above in note 5 , $\S \S \mathrm{I2-2}$ to -8 , at 789-84I; Larry A. Alexander, Trouble on Track Two: Incidental Regulations of Speech and Free Speech Theory, 44 HASTINGs L.J. 92 I passim (1993); John H. Ely, Flag Desecration: A Case Study in the Roles of Categorization and Balancing in First Amendment Analysis, 88 HARV. L. REV. 1482 passim (1975); and, Susan H. Williams, Content Discrimination and the First Amendment, I39 U. PA. L. REv. 6I5, 722-28 (Iggr). 
lation is content-based or content-neutral.99 Content-based regulations aim at the communicative impact of communicative activity, whereas content-neutral regulations merely have an adverse effect on communicative opportunity. ${ }^{100}$ As Geoffrey Stone notes, in practice the Court applies a deferential standard of review to most content-neutral restrictions, ${ }^{101}$ including imcidental burdens that arise from content-neutral restrictions. ${ }^{102}$ Stone summarizes the Court's approach to incidental burdens as follows:

The general presumption is that incidental restrictions do not raise a question of first amendment review. The presumption is waived, however, whenever an incidental restriction either has a highly disproportionate impact on free expression or directly penalizes expressive activity. And the latter exception is applied quite liberally whenever the challenged restriction significantly limits the opportunities for free expression. ${ }^{103}$

Examples that illustrate Stone's general proposition abound. For instance, "newspapers can properly be inade to comply with the antitrust laws, to obey generally applicable labor laws, and to pay taxes imposed under a generally applicable tax sclieme."104 Any contention that speakers should be exempt from such government regulation is at best impractical in light of the pervasiveness of government regulation in the modern state. ${ }^{105}$ Nonetheless, imcidental burdens frequently arise that present at least a strong prima facie case for heiglitened

99 The scope and even the existence of the content-neutrality requirement vary significantly from context to context. See Steven H. Shiffrin, The First Amendment, Democracy, AND Romance I7-33 (1990); Richard H. Fallon, Jr., Sexual Harassment, Content Neutrality, and the First Amendment Dog That Didn't Bark, I994 SUP. CT. REV I, 2 I-28.

100 See TRIBE, supra note 5, § 12-2, at 790 .

101 See Stone, supra note $\mathrm{II}$, at 50-52. Recent cases suggest a greater willingness by the Court to apply a more stringent form of intermediate scrutiny to content-neutral regulations of speech. See, e.g., Madsen v. Women's Health Ctr., Inc., II4 S. Ct. 2516, 2523, 2530 (I994) (treating an injunction against antiabortion protestors' activities outside a health clinic as content-neutral, but nonetheless invalidating portions of the injunction as imposing greater burdens on speech than necessary); Turner Broadcasting Sys. v. FCC, 114 S. Ct. 2445, 246I-62, 2469-72 (I994) (plurality opinion) (treating the must-carry provisions of the Cable Television Consumer Protection and Competition Act of 1992 as content-neutral and finding a substantial government interest, but remanding for application of the narrow-tailoring prong of the test from United States v. O'Brien, 391 U.S. 367,377 (1 968$)$ ).

102 See Stone, supra note Ir, at ro5-14.

103 Id. at II 4 .

104 Schauer, supra note 94, at 779-80 (citing inter alia Minneapolis Star \& Tribune Co. v. Minnesota Comm'r of Revenue, 460 U.S. 575,579 (rg83) (invalidating a special use tax on newspaper and ink); Citizen Publisling Co. v. United States, 394 U.S. 13I, I35 (196g) (antitrust); and, Oklahoma Press Publishing Co. v. Walling, 327 U.S. 186, I92 (I946) (labor)).

105 Moreover, any form of leightened scrutiny for all incidental burdens could be costly, because one cannot assume that the government's asserted interest will inevitably justify the regulation. For example, is the government's interest in the marginal increase in revenue that it derives from taxes on newspapers sufficiently compelling? Additionally, even if the challenged regulation would survive heightened scrutiny, litigation expenses may preclude the government from defending such a regulation in court. 
scrutiny. The leading case of United States $v$. O'Brien ${ }^{106}$ presents the starting point for deciding whether an incidental burden on speech triggers such scrutiny.

In O'Brien, the defendant was prosecuted under a federal statute that prohibited the knowing destruction or mutilation of draft cards. ${ }^{107}$ Although O'Brien had burned his draft card as a communicative act of pohtical protest, ${ }^{108}$ the Court did not conclude on this basis alone that the First Amendinent was inphicated. The Court rejected "the view that an apparently limitless variety of conduct can be labeled 'speech' whenever the person engaging in the conduct intends thereby to express an idea." 109 It then announced a four-prong test applicable to regulations not aimed at expression but which have the effect of restricting symbolic speech: first, the regulation must be "within the constitutional power of the Government"; second, it inust further "an important or substantial governmental interest"; third, that interest must be "unrelated to the suppression of free expression"; and fourtb, "the incidental restriction on alleged First Ainendment freedouns [must be] no greater than is essential to the furtherance of that interest."110

Prong one is not properly part of First Amendinent law, because all regulation must be within the government's constitutional power. ${ }^{111}$ Prong three merely restates the proposition that the challenged regulation inust be content-neutral - which is a precondition for the apphication of the test in the first instance. The O'Brien test thus can be distilled into a two-part requirement that formally resembles conventional interınediate scrutiny: a regulation inust serve a substantial government interest and unust be narrowly tailored to that end in order to pass constitutional inuster. ${ }^{112}$

The Court has unade clear, however, that the narrow tailoring element of the O'Brien test does not require that the regulation he the

10639 I U.S. 367 (1968).

107 See id. at 369-70.

108 See Keith Werhan, The O'Briening of Free Speech Methodology, I9 ARJz. ST. L.J. 635, 635 (I987) (citing O'Brien, 39I U.S. at 369-70; and, Brief for David Paul O'Brien at 6, O'Brien (No. 232), reprinted in 65 LANDMARK BRIEFs AND ARgUMENTS OF THE SUPREME CoURT OF THE UNITED STATES 80I, 819 (Philip B. Kurland \& Gerhard Casper eds., 1975)).

109 O'Bnen, 391 U.S. at 376 .

110 Id. at 377. Over the years, the Court has apphed the O'Brien test not only to cases of incidental burdens on symbolic speech, such as burning a draft card or sleeping in a park as acts of political protest, see Clark v. Community for Creative Non-Violence, 468 U.S. 288, 298 (1984), but also to content-neutral regulations that directly burden speech, see Werhan, supra note 108, at $637-38$ \& nn.9-I4.

111 For federal laws, this prong means that Congress must be exercising one of its enumerated powers. So far as the federal Constitution is concerned, the states' powers are plenary.

112 See, e.g., Craig v. Boren, 429 U.S. I9o, I97 (I976) (stating that "classifications by gender must serve important governmental objectives and must be substantially related to achievement of those objectives"). 
least restrictive means of achieving the state imterest. ${ }^{113}$ As John Hart Ely observed, in the O'Brien context narrow tailoring requires "only that there be no less restrictive alternative capable of serving the state's interest as efficiently as it is served by the regulation under attack."114 This approach amounts to no more than a prohibition on "gratuitous mhibition of expression." 115 In contrast, classic heightened scrutiny of more traditional forms of expression asks "whether the marginally greater effectiveness of [the challenged restriction on speech] relative to alternative means of [achieving the same objective] justifies the greater burden on communication."116

113 See Ward v. Rock Against Racism, 49r U.S. 781, 797-98 (rg8g). Although Ward is a time, place, and manner case, the Court stated that the O'Brien standard and the time, place, and manner standard are similar. See id. at 798 ("IT]he O'Brien test ' . . . is little, if any, different from the standard applied to time, place, or manner restrictions." (quoting Clark, 468 U.S. at 298)); see also Alexander, supra note 98 , at 928 ("[T]he Court is correct, from a theoretical standpoint, in employing the same test for both areas."); David S. Day, The Hybridization of the Content-Neutral Standards for the Free Speech Clause, 19 ARIZ. ST. L.J. 195, 214-I5 (1987) (noting the apparent merger of the historically distinct $O^{\prime} B r i e n$ test and the time, place, and manner test). The domain of the O'Brien and Ward test now also includes commercial speech. See Board of Trustees v. Fox, 492 U.S. 469,477 (Ig89) (terming the tests "substantially similar" (quoting San Francisco Arts \& Athletics, Inc. v. United States Olympic Comm., 483 U.S. 522, 537 n.r6 (I987))). But cf. City of Cincinnati v. Discovery Network, Inc., I13 S. Ct. 1505, 1516-17 (1993) (invalidating a municipal regulation prohibiting placement of commercial but not noncommercial newsracks on public property). Ashutosh Bliagwat has noted the oddity that in Discovery Network the Court forbade a city from relying on the very categories that the Court's own First Amendment jurisprudence had created. See Ashutosh Bhagwat, Of Markets and Media: The First Amendment, the New Mass Media, and the Political Components of Culture, 74 N.C. L. REv. I4I, I63 n.IOI (rg95).

114 Ely, supra note 98 , at $1484-85$.

115 Id. at 1485 .

116 Id. at I486-87. Note that when Ely made these observations in 1975, one could plausibly have argued that the Supreme Court's free speech jurisprudence consisted of four distinct tests. First, the Court sometimes held that content-based speech restrictions were per se invalid unless the speech fell within a proscribable category. See id. at I490-9I (discussing Brandenburg v. Ohio, 395 U.S. 444 (rg69) (per curiam)). Second, the Court applied bona fide heightened scrutiny to content-neutral laws directed at traditional speech. See id. at $\mathrm{I} 486-87$ (discussing the handbill ban invalidated in Schneider v. State, 308 U.S. I47, I60, I62 (I939)). Third, the Court applied the no-gratuitous-regulation approach of $O^{\prime} B r i e n$ to some instances of speech mixed with conduct. See United States v. O'Brien, 39I U.S. 367, 377 (rg68). Fourth, the Court applied no special First Amendment scrutiny to incidental burdens arising out of laws having no obvious connection to speech. See, e.g., Citizens Publishing Co. v. United States, 394 U.S. I3I, I39-I40 (I969) (holding that newspapers lack immunity from the antitrust laws). The second, third, and fourth tests continue to exist essentially unchanged, but the per se rule appears to have collapsed into the second test. Thus, all content-based speech restrictions are now judged by the same strict scrutiny standard applied to content-neutral regulations of traditional speech. See Simon \& Schuster, Inc. v. Members of the N.Y. State Crime Victims Bd., 502 U.S. 105, I24-28 (I9gI) (Kennedy, J., concurring in the judgment) (criticizing the majority's application of strict scrutiny and proposing the alternative of per se invalidation of content- and speaker-based restrictions of speech); see also Alexander, supra note 98 , at 926 (employing a different typology, which includes a distinct category for "cases where government is using the mechanisms of the affirmative state, not to censor others' messages, but to communicate its own messages"). 
Given that the O'Brien test asks so little in principle, it should not be surprising that it means so hittle in practice. In some sense, the O'Brien test is the worst of all possible worlds. A large category of content-neutral laws is susceptible to an O'Brien challenge. Litigation over regulations in this category imposes substantial costs on society but yields few tangible benefits. Because most of the challenged laws will survive, most of the cases actually litigated will not benefit free speech. Nor does the prospect of O'Brien scrutiny deter potentially speech-chilling laws, because legislators enacting content-neutral laws will not ordinarily contemplate free speech issues: by definition, such laws are aimed at problems that do not arise from the coinmunicative impact of speech. ${ }^{117}$ Thus, if O'Brien scrutiny is to remain toothless, it hardly seeins worth retaining as a discrete First Amendinent test. ${ }^{118}$

Before completely abandoning the O'Brien test - and thus forsaking the possibility of reconciling free speech doctrine with the insight that incidental burdens matter - we should ask whether the test can be improved. The obvious first step would be to bring its application into line with its language. Because the O'Brien test, by its terms, resembles heightened (if not strict) scrutiny, we might ask whether a sensible doctrine could be constructed that would apply some form of truly heightened scrutiny to some class of incidental burdens on speech. We would have to find a way to avoid the application of heightened scrutiny to a "limitless variety of conduct."119 The Supreme Court suggested a methodology for accomplishing this task in

117 One might be tempted to point to O'Brien itself as a counterexample. In that case, Congress clearly understood, and indeed intended, the law to penalize antidraft expression. But this point merely highlights that the O'Brien Court misapplied the test that it announced. In nearly all instances, the knowing destruction or mutilation of a draft card was undoubtedly undertaken to communicate a message. The mere fact that one can hypothesize unusual circumstances under which a given law reaches only noncommunicative conduct - for example, someone burning a draft card for warmth - does not render a content-based regulation content-neutral. The O'Brien Court misapplied the third prong of its test because the government interest in preventing draft card destruction and mutilation was not "unrelated to the suppression of free expression." O'Brien, 39 I U.S. at 377 .

118 See Larry Alexander, Free Speech and Speaker's Intent, I2 Const. Comment. 21, 26 (I995) (contending that heightened judicial scrutiny of content-neutral laws "has been an extremely unsuccessful jurisprudential exercise, with only a ferv very arbitrary victories for speakers in a period of over fifty years," and that it "should be dropped from first amendment analysis"); Alexander, supra note 98 , at 925 . The Supreme Court itself has sometimes flirted with this approach. See Cohen v. Cowles Media Co., 50r U.S. 663, 669 (I99I) (noting that "generally applicable laws do not offend the First Amendment simply because their enforcement against the press has incidental effects on its ability to gather and report the news"); Barnes v. Glen Theatre, Inc., 50r U.S. 560, 576 (1991) (Scalia, J., concurring in the judgment) (stating that "a general law not specifically targeted at expressive conduct, [does not in] its application to such conduct . . . implicate the First Amendment").

119 O'Brien, 39 I U.S. at 376. 
Arcara v. Cloud Books, Inc., ${ }^{120}$ in which the Court subjected an incidental burden on speech to no First Amendment scrutiny at all. ${ }^{121}$

In Arcara, a New York statute authorizing the closure of any building being used for "prostitution" or "lewdness" was applied to a store that sold sexual (but not obscene) books, because the store was in fact used as a place of prostitution and open sexual conduct. ${ }^{122}$ The Supreme Court rejected the storeowner's claim that some form of heightened scrutiny under the First Amendment was appropriate. The Court did not even apply O'Brien. ${ }^{123}$.

After stating what it saw as the general principle that incidental burdens raise no constitutional issue, ${ }^{124}$ the Arcara Court suggested two exceptions. First, the Court observed that incidental restrictions that "impose a disproportionate burden upon those engaged in protected First Amendment activities" trigger lheightened First Amendment scrutiny. ${ }^{125}$ This category comprises regulations that, although formally not directed at expression, apply to speech so disproportionately as to suggest that the government is targetimg speech. A law imposing a special tax on ink is one example. ${ }^{126}$ So too is a law banning all flag burning, because the burning of a flag is almost always a communicative activity. This first exception really rests upon a judgment that laws subjecting speech to grossly disproportionate burdens are not incidental burdens at all. ${ }^{127}$

Second, the Court noted that First Amendment scrutiny applies when a law penalizes expressive activity. ${ }^{128}$ This exception can be illustrated by contrasting O'Brien with Arcara. In O'Brien, the activity

\footnotetext{
120478 U.S. 697 (1986).

121 See id. at $706-07$.

122 See id. at 698-700.

123 See id. at 706-07.

124 See id. at $704-05$.

125 Id. at 704 .
}

126 See Minneapolis Star \& Tribune Co. v. Minnesota Comm'r of Revenue, 460 U.S. 575, 578 (1983). Note that the government's targeting of expression need not, however, reflect an illicit motive in order to trigger strict scrutiny. See id. at 592 ("We need not and do not impugn the motives of the Minnesota Legislature in passing the ink and paper tax."). See generally infra section III.A (discussing the distinction between targeted regulations and purposefully restrictive regulations).

127 It may appear problematic to focus on the likelihood that an activity will be communicative. But it should be noted that such an inquiry is unavoidable. Even what we normally term "pure" speech is only commumicative in nearly all cases, rather than all cases. A law prohibiting "uttering words disrespectful of the government" targets the communicative impact of speech, notwithstanding the fact that someone might utter words disrespectful of the government without intending to express any message. For example, a person recovering from reconstructive jaw surgery might recite such a speech solely as a means of exercising her jaw. Cf. Akhil R. Amar, The Case of the Missing Amendments: R.A.V. v. City of St. Paul, ro6 HARv. L. REv. 124, 133-34 (1992) (noting that spoken or printed words are acts that typically communicate); Tribe, supra note 27 , at 32 (discussing "activities that are usually associated with or engaged in solely for the purpose of expressing certain messages or ideas"). .

128 See Arcara, 478 U.S. at $706-07$ \& n.3. 
that triggered the penalty - destruction or mutilation of a draft card - was communicative, at least from the perspective of the private actor. In Arcara, the activities that triggered the penalty - prostitution and open sexual conduct - were not communicative, even from the private actor's perspective. The burden on speech could have been entirely avoided had the bookstore owner refrained from engaging in the unprotected, noncommunicative activity. ${ }^{129}$ Although there certainly was state action in the constitutional sense, the burden on speech was not directly attributable to the government; rather, the private actor's decision to connect the noncommunicative activity with the selling of books created the burden on speech. ${ }^{130}$

Consider an example taken from Justice O'Connor's concurrence in Arcara. A law prohibiting speeding unay delay a motorist who happens to be a television newscaster, and thereby interfere with his ability to engage in the communicative activity of announcing the news. ${ }^{131}$ Yet we would not subject the law, when applied to the speeding newscaster, to heightened scrutiny under the First Amendment. According to Justice O'Connor, Arcara is a similar case. ${ }^{132}$

Nevertheless, the hypothetical speeding newscaster actually poses a more difficult problem than is immediately apparent. The activities that triggered the penalty in Arcara - prostitution and open sexual conduct - were not coinmunicative, even from the private actor's perspective. At first, it may appear that the same is true of the newscaster, who does not intend to send any message through speeding. However, the noncommunicative act of speeding does, from the newscaster's perspective, at least facilitate expression, because it permits him to arrive at the studio in time for the broadcast. Moreover, the saine can be said of the prostitution and open sexual conduct at issue in Arcara: these activities presumably played some role in enhancing the profitability of the sale of (presumptively protected) books - and thus, from the storeowner's perspective, they facilitated book sales. The newscaster example and Arcara itself thus suggest a need

129 I make the suggestion that banning unprotected noncommunicative activity raises no First Amendment problems tentatively. As Sherry Colb has noted, the distinction between prohibiting a protected activity and punishing an unprotected activity by depriving a person of a fundamental right may not be constitutionally significant. See Sherry F. Colb, Freedom from Incarceration: Why Is This Right Different from All Other Rights?, 69 N.Y.U. L. REv. 781, 803-13 (1994) (arguing that the penalty of imprisonment deprives the prisoner of the fundamental right to liberty, and thus criminal laws that call for imprisonment should be subject to strict scrutiny even when the underlying activity criminalized is not itself constitutionally privileged).

130 Although I once found this distinction between O'Brien and Arcara essential, see TruBE \& DORF, supra note 55 , at $35-36, I$ am no longer persuaded that it provides a complete answer to the incidental burden puzzle.

131 See Arcara, 478 U.S. at 708 (O'Connor, J., concurring).

132 See id. 
for distinguishing between activities that merely facilitate expression and those that are, in and of themselves, truly communicative. ${ }^{133}$

Looking to facilitation, however, may be problematic because one can always isolate the noncommunicative elements of communicative conduct and characterize them as facilitative of the expression. Thus, in O'Brien the physical act of burning the draft card could be said to facilitate expression of hostility to the draft. To be sure, in O'Brien the communicative and noncommunicative elements were intertwmed in a way that they were not entangled in Arcara or the newscaster example. However, from the speaker's perspective, there may be no important difference between a burden on an act that facilitates expression and a burden on an act that is more highly intertwined with expression. As Ely put it, "burning a draft card to express opposition to the draft is an undifferentiated whole, I00\% action and I00\% expression." 134

Moreover, even if one believes that the categories of facilitative and speech-mtertwined acts can be distinguished, it is not clear that they should be. At issue in Clark v. Community for Creative NonViolence, ${ }^{135}$ for example, was the application of a federal regulation that prohibited most camping in national parks to persons wlio wished to sleep in a park opposite the White House for the purpose of protesting government policy with respect to the liomeless. ${ }^{136}$ The Clark Court apphed O'Brien scrutiny. ${ }^{137}$ This level of scrutiny appears to be the right one, because the message was intertwined with the physical act of sleeping. Suppose, however, that the regulation instead liad prohibited "entering or remaining in the park after niglitfall." Applied to the same protestors, such a regulation could be said to burden only an act that facilitates communication rather than one that is intertwined with communication. The protestors' message would not be intertwined with the act of entering or remaining in the park; these acts would merely facilitate sleeping in the park - which itself would be intertwined with their message. Yet it would be odd to subject the sleeping prohibition to greater scrutiny than the entering or remaining prohibition when neither aims at communication and both have the incidental effect of burdening the same coinmunication.

133 The Supreme Court suggested such a distinction in Clark v. Community for Creative NonViolence, 468 U.S. 288, 296 ( 1984 ) (explaining that the "major value to this demonstration [of sleeping in Lafayette Park] would be facilitative").

134 Ely, supra note 98 , at 1495 . I believe that Ely's point is not that the lines between facilitative and intertwined acts are difficult to draw, but that they are inevitably artificial. But see Williams, supra note 98 , at $723-24$ (placing the speeding-newscaster hypothetical in a category of "incidental" burdens that do not even affect facilitative acts, and arguing that communicative, facilitative, and other activities lie along a spectrum).

135468 U.S. 288 ( 1984 ).

136 See id. at 294 .

137 See id. at 293 . 
If one finds that the distinction between acts that facilitate speech and acts that are intertwined with speech is an inadequate basis upon which to build an incidental burden doctrine, one response would be to apply O'Brien scrutiny to both categories. But if that were done, the domain of O'Brien would be too broad, because a virtually limitless number of regulable activities can be "coinmunicative" (in the sense of intertwimed with or facilitative of speech). Indeed, even if one adheres to the facilitative/intertwined distinction and only scrutinizes burdens on the latter category, O'Brien's reach appears too broad. For example, a residential zoning ordinance may prevent the operation of a theater, bookstore, or newspaper plant at a particular site. ${ }^{138}$ Yet in the zoning case, the attempt to run a theater, bookstore, or newspaper is, like O'Brien but arguably not like Arcara, intertwined with the noncommunicative element of operating a commercial establishment.

Perliaps because of the O'Brien test's broad scope, the Court has applied it in a manner that is extremely deferential to the government. As a means of controlling the floodgates, this approach may be sensible, but the result lias often sanctioned severe incidental burdens. ${ }^{139}$ Consequently, the Court has produced an incidental burden doctrine with a too-broad doinain and a too-weak practical effect.

Although sometimes characterized as a distinct aspect of free speecli law, the doctrines governing time, place, and manner regulations of speecli in a public forum suggest a workable approach to the mcidental burden question. As Frederick Schauer observes, public foruin doctrine represents an exception to the general First Amendment principle that the courts will not closely scrutinize incidental regulations. ${ }^{140}$ For exainple, suppose that a city ordinance prohibiting "all activities that liave the potential to block pedestrian traffic on a sidewalk" were applied to a person making a political speecl on the sidewalk around whom a crowd liad gathered. ${ }^{141}$ Although the ordinance imposes only an incidental burden on speech, its application would be judged by heiglitened scrutiny. ${ }^{142}$ Public forum doctrine recognizes that, by denying speakers access to those areas in which potential lis-

138 Note that such an ordinance would have only an incidental effect on expression, in contrast with zoning ordinances targeted at particular kinds of expression. But see Renton v. Playtime Theatres, Inc., 475 U.S. 4I, 47-50 (1986) (applying the O'Brien test to a zoning ordinance limited to theaters showing sexually explicit films, because the regulation targeted the "secondary effects" of such films).

139 See, e.g., Clark, 468 U.S. at $298-99$.

140 See Schauer, supra note 94 , at 788-89.

141 See id. at 788 (giving this example).

142 See TRIBE, supra note $5, \S 12-24$, at 987 ("The 'public forum' doctrine holds that restrictions on speech should be subject to higher scrutiny when, all other things being equal, that speech occurs in areas playing a vital role in communication - such as in those places historically associated with first amendment activities, such as streets, sidewalks, and parks."). Schauer's hypothetical ordinance could not be sustained as a time, place, or manner regulation, because it forecloses all opportunities to use the sidewalks for large-scale communicative activity. 
teners are most likely to concentrate, even a law not directed at speech can amount to an infringement of the right to free speech, because it substantially interferes with a vital means of exercising the right. ${ }^{143}$

The Court's time, place, and manner test similarly suggests that the concern underlying public forum doctrine is the ability of speakers to communicate effectively. Even in a public forum, the government may impose content-neutral time, place, and inanner restrictions if it leaves open adequate alternative channels of communication. ${ }^{144}$ For example, a prohibition on sound trucks in residential neighborhoods is permissible, notwithstanding its restrictive effect on expression, in part because speakers may be able to communicate their messages nearly as effectively through less disruptive means. ${ }^{145}$

Time, place, and manner doctrine suggests a means of distinguishing between significant and insignificant incidental burdens: only those mcidental burdens that do not leave open adequate alternative channels of communication should be subject to heightened scrutiny. ${ }^{146}$ Most time, place, and manner restrictions impose direct burdens on speech, because they apply exclusively to communicative activity. But because a valid time, place, and manner regulation must be contentneutral, it, like the archetypal incidental burden, will be directed at the noncommunicative aspects of the regulated activity. ${ }^{147}$ Indeed, the Court lias recently held that the incidental burden test for free speech and the time, place, and manner test are substantially the same. ${ }^{148}$ Therefore, whatever its official shape, free speech doctrine requires close scrutiny of an incidental burden on speech only when the burden

143 It may appear odd to treat public forum doctrine as a subset of incidental burden doctrine, because for example, a government decision to bulldoze a park - thereby incidentally rendering speech in the park impossible - would raise no First Amendment issue. See International Soc'y for Krishna Consciousness v. Lee, II2 S. Ct. 27 II, 2718 (I992) (Kennedy, J., concurring in the judgment) ("In some sense the government always retains authority to close a public forum, by selling the property, changing its physical character, or changing its principal use."). The inconsistency is more apparent than real, however. Once the government property loses its public forum character, the public will find other places to congregate, presumably in other public fora. At that point, potential speakers will need access to these other places. To the extent that the disappearance of traditional public spaces results in public congregation in places that do not constitute traditional public fora, the Court's recent reluctance to recognize that a nontraditional public space can constitute a public forum, see id. at 2717 (criticizing the Court's holding that a government-owned airport is not a public forum), undermines the purpose of public forum doctrine.

144 See Ward v. Rock Against Racism, 491 U.S. 781, 79I (I98g) (citing Clark v. Community for Creative Non-Violence, 468 U.S. 288, 293 (1984)).

145 See Kovacs v. Cooper, 336 U.S. 77, 82-83, 89 (1949).

146 See Schauer, supra note 94 , at 791 (suggesting that a successful limiting principle for incidental burden doctrine might "focus on alternative channels of communication").

${ }^{147}$ See, e.g., Ward, $49 \mathrm{I}$ U.S. at 803 (upholding the requirement that musical performers in New York's Central Park utilize the city's sound engineer as a content-neutral regulation aimed at reducing the decibel level of concerts); Schauer, supra note 94, at 791 .

148 See supra note $\mathrm{I}$ I3 (discussing Ward). 
forecloses an essential avenue of communication. In short, only substantial incidental burdens trigger heightened scrutiny. ${ }^{149}$

This account leaves us with a number of practical puzzles. How do we determme whether an incidental burden is substantial? In order to trigger heightened scrutiny, must a law foreclose all alternative avenues of communication or only some of them? At what level of generality do we describe the speaker's chosen means of expression and the putative alternatives? For example, is the possibility of distributing homemade videotape cassettes an adequate alternative means of dissemmating a video message for someone who cannot afford to purchase time on broadcast or cable television? ${ }^{150}$ To what extent may one medium substitute for another one?151 I do not attempt to answer these practical questions here, because they cannot be adequately addressed in the abstract.

As a general matter, free speech doctrine treats substantial incidental burdens as raising a bona fide constitutional problem and ignores most other incidental burdens. Although the Court has not expressly justified its approach im such terms, the doctrine appears to be a reasonable compromise between the reasons for taking incidental burdens seriously and the floodgates concern.

\section{B. Incidental Burdens on Free Exercise of Religion}

In Employment Division v. Smith, ${ }^{152}$ the Supreme Court adopted a simple rule for judging the constitutionality of a law imposing an incidental burden on the free exercise of religion. According to Smith, essentially all incidental burdens imposed by neutral laws are constitutional. ${ }^{153}$ Only laws that single out religious conduct for particular

149 Note that I am equating two requirements that the Court's doctrine apparently treats as distinct: the requirement that time, place, and manner regulations leave open adequate alternative means of expression, and the prohibition on foreclosing an essential avenue of communication. Both of these requirements derive from a basic concern that communication rights should not be substantially burdened.

150 We might choose to ignore all incidental burdens that operate through a private actor's indigence. Although such an approach would be broadly consistent with the Supreme Court's unwillingness to recognize positive rights, see, e.g., Rust v. Sullivan, 500 U.S. 173, 203 (1990) (upholding a prohibition on abortion-related counseling by doctors working for federally funded family planming clinics); Harris v. McRae, 448 U.S. 297, 326 (r980) (upholding state funding of all medical treatments except abortions); Maher v. Roe, 432 U.S. 464, 479-80 (1977) (rejecting constitutional challenges to state probibitions on the use of Medicaid benefits for funding abortions), the Court has recognized that the impact of a law on "the poorly financed causes of little people" is a relevant consideration in free speech analysis, Members of the City Councii v. Taxpayers for Vincent, 466 U.S. 789, 812 n.30 (1984) (quoting Martin v. City of Struthers, $3^{19}$ U.S. 141, 146 (r943) (internal quotation marks omitted)); see infre section III.D.

151 Cf. Leathers v. Medlock, 499 U.S. 439,453 (I99I) (upholding a generally applicable state sales tax that applied to cable television operators but not to print media or satellite broadcasters).

152494 U.S. 872 (1990).

153 See id. at $877-79$. In an effort to reconcile its holding with prior precedent, the Smith Court recognized two exceptions to its blanket principle. First, cases involving a "hybrid" of free 
burdens trigger heightened scrutiny under the Free Exercise Clause. ${ }^{154}$ Regardless of the actual impact of a law on a particular religious practice, the law will be upheld without any inquiry into the strength or weakness of the government interest.

The rule of Smith has been severely criticized. ${ }^{155}$ Justice Souter, who joined the Court after Smith was decided, has even suggested that Smith should be overruled as unsound and inconsistent with cases that it purported to leave undisturbed as good law. ${ }^{156}$ Criticism of Smith has not been confined to academic or judicial circles. With broad support from both major pohtical parties and diverse interest groups, ${ }^{157}$ Congress passed and the President signed the Rehgious Freedom Restoration Act of I993 (RFRA), ${ }^{158}$ which provides significant statutory protection against incidental burdens on the free exercise of religion. RFRA provides that "[g]overnment shall not substantially burden a person's exercise of religion even if the burden results from a rule of general applicabihty,"159 unless the burden imposed is narrowly tailored to serve a compelling interest. ${ }^{160}$

exercise and other constitutional rights would not be subject to the Court's rule, presumably because such rights would receive robust protection independently. See id. at $88 \mathrm{I}$ (placing Wisconsin v. Yoder, 406 U.S. 205 ( 1972 ), in this category). Second, the Court distinguished claims for religious exceptions to unemployment ehigibihty rules, because of the possibility of "individualized governmental assessment of the reasons for the relevant conduct." Id. at 884 (classifying Sherbert v. Verner, 374 U.S. 398 (1963), and Thomas v. Review Bd., 450 U.S. 707 (I98I), under this exception); see also Christopher L. Eisgruber \& Lawrence G. Sager, The Vulnerability of Conscience: The Constitutional Basis for Protecting Religious Conduct, 6I U. CHI. L. REv. I245, I287 (I994) (accepting the second distinction, because a regime of ad hoc administrative exceptions threatens unequal treatment of minority religions).

154 See Church of the Lukumi Babalu Aye, Inc. v. City of Hialeah, Iry S. Ct. 2217, 2225-26 (rg93) (invalidating a series of ordinances because they singled out ritual animal sacrifice by practitioners of the Santeria faith for prohibition).

155 See, e.g., Douglas Laycock, The Remnants of Free Exercise, Iggo Sup. CT. REv. I, I; Ira C. Lupu, The Lingering Death of Separationism, 62 GEo. WASH. L. REV. 230, $250-53$ (1994); MCConnell, supra note 14, at IIII; see also David L. Gregory, Religious Harassment in the Workplace: An Analysis of the EEOC's Proposed Guidelines, 56 MONT. L. REv. II9, I19 n.2 (1995) (citing a number of sources critical of Smith). But see William P. Marshall, In Defense of Smith and Free Exercise Revisionism, 58 U. CHI. L. REV. 308, 309 (1991) (approving the result but not the reasoning of $S$ mith).

156 See Church of the Lukumi Babalu Aye, I13 S. Ct. at 2240-50 (Souter, J., concurring in part and concurring in the judgment).

157 See Daniel O. Conkle, The Religious Freedom Restoration Act: The Constitutional Significance of an Unconstitutional Statute, 56 MONT. L. REv. 39, 39 (1995) ("RFRA was supported by a legion of divergent interest groups, and it garnered virtually unanimous support in both the House and the Senate." ); Gustave Niebuhr, Disparate Groups Unite Behind Civil Rights Bill on Religious Freedom, WASH. PosT, Oct. I6, I993, at A7 (citing support of 68 diverse religious and civil liberties groups); Senate Votes to Protect Religion, WASH. POST, Oct. 28, r993, at A8 (noting Senate approval by a 97-2 margin).

158 Religious Freedom Restoration Act of I993, Pub. L. No. I03-I4I, I07 Stat. I488 (codified at 42 U.S.C. \& 2000 bb (Supp. V I993)).

159 Id. \& $2000 \mathrm{bb}-\mathrm{I}(\mathrm{a})$.

160 See id. \$2000bb-I(b). 
Serious questions have been raised regarding the constitutionality of RFRA. According to one district court's view, RFRA violates separation of powers principles because Congress may not substitute its constitutional views for those of the Court. ${ }^{161}$ Others clain that, insofar as RFRA limits the states and not just the federal governunent, ${ }^{162}$ Congress lacks the affirmative power to enact RFRA under either the Commerce Clause or Section Five of the Fourteenth Ainendment. 163 A third view focuses on equality norms. It suggests that the faithful application of RFRA will sometimes favor rehgious persons or institutions over nonrehgious ones in a manner that violates establishment, equal protection, and free speech principles. ${ }^{164}$

Although these views pose difficult and fascinating questions, for present purposes I assume the constitutionality of RFRA and inquire into its ineaning. RFRA suggests a potentially useful approach to the problein of incidental burdens, regardless whether we consider the problein to be one of statutory construction, constitutional interpretation, or purely academic speculation.

The language of RFRA reflects a coinproinise between the two considerations upon which this Article has focused. On the one hand, RFRA expressly recognizes that "laws 'neutral' toward religion may burden religious exercise as surely as laws intended to interfere with religious exercise." ${ }^{165}$ On the other hand, in an apparent effort to

161 See Flores v. City of Boerne, 877 F. Supp. 355, 358 (W.D. Tex. 1995), rev'd, 73 F.3d I352 (5th Cir. 1996); see also Joanne C. Brant, Taking the Supreme Court at Its Word: The Implications for RFRA and Separation of Powers, 56 MONT. L. REV. 5, 6 (1995) (arguing that Smith rested on an assessment of judicial (in)competence that Congress may not overturn); Eisgruber \& Sager, supra note 153, at I309 (questioning RFRA's use of "a conceptual vocabulary that is abidingly constitutional"); Ira C. Lupu, Of Time and the RFRA: A Lawyer's Guide to the Religious Freedom Restoration Act, 56 MONT. L. REV. 171, 173 (1995) (terming RFRA "a challenge to the concept of judicial supremacy in the interpretation of the Constitution ${ }^{\prime}$ ).

162 See Lupu, supra note $\mathrm{I} 6 \mathrm{I}$, at 173 (linking the question of Congress's affirmative power to questions of federalism). As a restraint on the federal government, RFRA is less problematic. It is both a rule of interpretation for future [and past] federal legislation and an exercise of general legislative supervision over federal agencies, enacted pursuant to each of the federal powers that gives rise to legislation or agencies in the first place." Douglas Laycock \& Oliver S. Thomas, Interpreting the Religious Freedom Restoration Act, 73 TEx. L. REv. 209, 2II (I994); see also Michael S. Paulsen, A RFRA Runs Through It, 56 MONT. L. REV. 249, 253 (I995) ("Congress possesses the same power to pass RFRA, as RFRA concerns federal statutes, as it had to pass those other federal statutes in the first place."). Laycock is the most ardent defender of RFRA's constitutionality in regard to the states as well. He argues that $\$ 5$ of the Fourteenth Amendment authorizes Congress to define constitutional guarantees more broadly than does the Court, so long as Congress does not thereby contravene the Court's interpretation of other constitutional requirements. See Douglas Laycock, RFRA, Congress, and the Ratchet, 56 MONT. L. REv. 145, 152-69 (I995).

163 See Conkle, supra note 157, at 61-70; Eisgruber \& Sager, supra note 153, at 1308.

164 See William P. Marshall, The Religious Freedom Restoration Act: Establishment, Equal Protection and Free Speech Concerns, 56 MonT. L. REv. 227, 228-29 (1995); cf. Eisgruber \& Sager, supra note 153 , at 1308 (suggesting that RFRA may violate the authors' understanding of religious liberty, a principle which they term "equal regard").

16542 U.S.C. $\$ 2000 b b(a)(2)$ (Supp. V 1993). 
avoid the floodgates problem of subjecting all incidental burdens on religion to strict scrutiny, RFRA covers only "substantial" burdens. ${ }^{166}$

Neither the text nor the legislative history of RFRA provides any clear indication of how courts ought to determine whether an incidental burden on rehion is in fact substantial. The House report accompanying RFRA does reveal an "expectation that the courts will look to free exercise of rehgion cases decided prior to $S$ mith for guidance in determining whether or not religious exercise has been burdened."167 RFRA does not, however, simply restore the pre-Smith law. The text of RFRA specifies that its purpose is "to restore the compelling interest test as set forth im"168 two cases: Sherbert v. Verner ${ }^{169}$ and Wisconsin v. Yoder. ${ }^{170}$ RFRA would thus seem to endorse a specific version of the pre-Smith law, "the high-water mark of free exercise accommodation."171 Yet neither Sherbert nor Yoder gives a satisfactory explanation of the substantiahty threshold of RFRA.

In Sherbert, South Carolina had denied unemployment compensation to a Seventh-Day Adventist who refused to work on Saturday. ${ }^{172}$ In finding a free exercise violation, the Supreme Court did not use the precise phrase "substantial burden"; imstead, it analyzed the burden in the following terms:

The ruling [of the South Carolina Supreme Court] forces [the claimant] to choose between following the precepts of her religion and forfeiting benefits, on the one hand, and abandoning one of the precepts of her religion in order to accept work, on the other. Governmental imposition of such a choice puts the saine kind of burden upon the free exercise of religion as would a fine imposed against appellant for her Saturday worship. ${ }^{173}$

This approach provides little guidance for the substantiality inquiry, as the following hypothetical example illustrates. Suppose that

166 See id. § $2000 \mathrm{bb}(\mathrm{a})(3)$.

167 H.R. REP. No. 88, I03d Cong., Ist Sess. 6-7 (I993). One of the lower courts that has interpreted RFRA states that the substantiality requirement reflects the Supreme Court's preSmith jurisprudence. See Brown v. Borough of Mahaffey, 35 F.3d 846, 849 (3d Cir. 1994). Unfortunately, however, the pre-Smith case law is hardly coherent or definitive. As Ira Lupu has noted, interpretations of the Free Exercise Clause may be roughly divided into three historical periods. See Lupu, supra note 161, at 176-77. Prior to 1878, the Free Exercise Clause was essentially unenforced by the judiciary. Then in Reynolds v. United States, 98 U.S. I45 (1878), the Court held that the Clause protects religious behef but not conduct. See id. at 166-67 (upholding a prohibition on polygamy). The Court followed this approach until 1963 , when it sustained a free exercise challenge to an incidental burden in Sherbert v. Verner, 374 U.S. 398, 410 (1963). The Court purported to follow Sherbert's compelling interest test until Smith was decided but typically ruled against the religious claimant. See Lupu, supra note I6r, at 177 .

16842 U.S.C. $\$ 2000 \mathrm{bb}(\mathrm{b})(\mathrm{I})$.

169374 U.S. 398 (1963).

170406 U.S. 205 (1972).

171 Paulsen, supra note $\mathrm{I62}$, at 256.

172 See Sherbert, 374 U.S. at 399-402.

173 Id. at 404. 
the only route that a churchgoer may feasibly use to travel to church mvolves payment of a twenty-five-cent toll on a state-operated highway. Using the Sherbert analysis, the toll forces the individual to choose between, on the one hand, following the precepts of her religion by going to church and forfeiting the twenty-five cents or, on the other hand, abandoning the religious requirement of church attendance. Of course, forgoing unemployment benefits is a much greater sacrifice than paying a quarter, but nothing in the Sherbert analysis makes this fact significant. The Sherbert Court simply states that the incidental burden at issue is the equivalent of a targeted burden that would have the same impact; yet under this view, every incidental burden would trigger strict scrutiny.

The other case cited in RFRA, Wisconsin $v$. Yoder, is equally unilluminating. In Yoder, members of the Amish faith claimed an exemption from a Wisconsin requirement that children be educated until the age of sixteen. ${ }^{174}$ The Court held that the compulsory attendance law, as apphed to children born and raised in the Amish faith, threatened to undermme severely the entire Amish faith, ${ }^{175}$ and thus applied strict scrutimy. The question that Yoder does not answer, however, is how burdensome a law must be before the burden will be deemed substantial enough to trigger strict scrutiny.

On this question, the post-Yoder, pre-Smith law is not especially instructive. In two cases involving religious freedom claims by Native Americans, the Court held that government administration of its land or its internal programs imposed no burden on religion, even though the challenged actions were, in the plaintiffs' view, perilous to their spiritual well-being. ${ }^{176}$ Even if RFRA would not disturb these results, ${ }^{177}$ the cases do not provide any clear basis for a distinction between substantial and insubstantial burdens, because many incidental burdens that common sense would deem insubstantial will not relate to the government's own workings but instead will involve direct coercive measures taken by the state. ${ }^{178}$ The toll example discussed above is a case in point. ${ }^{179}$ Perhaps this example could be dismissed under an implicit de minimis exception to RFRA; such an exception,

174 See Yoder, 406 U.S. at 209.

175 See id. at 218.

176 See Lyng v. Northwest Indian Cemetery Protective Ass'n, 485 U.S. 439, 450-5I (I988) (finding strict scrutiny inapplicable to the government's proposed building of a road on sacred, albeit government-owned, land); Bowen v. Roy, 476 U.S. 693, 708-12 (1986) (finding strict scrutiny inapplicable to the government's internal assignment of a social security number to a child).

177 The funding for the actual road at issue in Lyng was ultimately withdrawn and the road relocated. See Eisgruber \& Sager, supra note 153, at I304 \& n.I15.

178 But see Thiry v. Carlson, 887 F. Supp. 1407, 1412-14 (D. Kan. 1995) (relying on Lyng to find no substantial burden under RFRA when the state condemned land on which the owners' stillboru daughter was buried and which they regularly visited to pray and to be near the child's spirit).

179 See supra pp. 1212-13. 
however, gives little guidance for closer cases. In short, RFRA, its legislative history, and the pre-Smith case law leave the essential distinction between substantial and insubstantial burdens largely undefined.

Given this definitional void, courts might be tempted to analogize incidental burdens on religion to those burdens falling on other rights, especially speech. RFRA establishes a test roughly equivalent to the one implicit in the Supreme Court's approach to incidental burdens on speech. ${ }^{180}$ Perhaps we can therefore utilize the concepts of free speech jurisprudence that provide the basis for that test. Returning to the example of the toll road to church, we might deem the burden insubstantial by relying on the facilitative/intertwined distinction sketched above in section II.A. ${ }^{181}$ Under this analysis, paying the toll facilitates religious exercise but is not intertwined with it. Before extending this approach, however, we should reconsider the practical and theoretical difficulties of the facilitative/intertwined distinction in free speech law. 182

Moreover, in adapting a free speech test to free exercise jurisprudence, a problem immediately arises - the concept of an alternative means of expression has no obvious free exercise analogue. As Kent Greenawalt explains, a "person who acts from religious conscience feels he has no alternative; a person expressing an idea wants to do so effectively, but probably does not feel some inner compulsion to use a particular means."183 For example, the law challenged in O'Brien merely made it more difficult for O'Brien to communicate his anti-war message as effectively as he liked, ${ }^{184}$ whereas the law challenged in Smith made it impossible for the Native Americans to engage in a required religious ritual. ${ }^{185}$

180 See supra section II.A.

181 See supra pp. 1206-08.

182 See supra pp. I206-og.

183 Kent Greenawalt, Free Speech in the United States and Canada, LAW \& ConTEMP. Probs., Winter I992, at 5, 27 (1992).

184 But see Williams, supra note 98 , at 706 (arguing that in symbolic speech cases such as $O{ }^{\prime} B r_{i e n}$, there can never be an adequate alternative means of expression, presumably because the medium is the message).

185 In the special context of prisoners' rights, in which the decisions of administrators are reviewed with minimal scrutiny, the Supreme Court has been less than sensitive to this distinction. In Turner v. Safley, 482 U.S. 78 ( 1987 ), the Court upheld a prison regulation prohibiting inmateto-inmate mail correspondence between different prisons, in part because the prohibition left inmates with alternative means of expression. See id. at 92. Barely a week later, in O'Lone v. Estate of Shabazz, 482 U.S. 342 ( 1987 ), the Court uplield the application of a prison schedule to Islamic inmates that prevented them from attending Jumu'ah, their religiously required Friday prayer services. See id. at 347,353 . Citing Safley, the Court noted that although there exist "no alternative means of attending Jumu'ah," $i d$. at $35 \mathrm{r}$, it was significant that the inmates retained "the ability to participate in other Muslim religious ceremonies," $i d$. at 352 . In Friedman v. Arizona, 912 F.2d 328 (9th Cir. 1990), the Ninth Circuit, noting that inmates could "participate in other aspects of their religion," applied Safley and O'Lone to uphold application of a prison regulation forbidding beards for Orthodox Jewish inmates. Id. at 332; see also Ward v. Walsh, I F.3d 
Can anything concrete be said about RFRA's substantiality threshold? Certainly, laws that have the incidental effect of rendering impossible the observation of a rehgious rite would constitute substantial burdens under the Act. The same would be true of laws that have the incidental effect of requiring the performance of a religiously proscribed act. These examples are easy cases, however. More difficult are cases in which a generally applicable law increases the cost (either monetary or other) of rehgious observation, but does not render it impossible. Ignoring incidental burdens that fall short of making a religious practice impossible or requiring a rehgiously proscribed act would provide a bright-line rule, but would significantly weaken protection for religion. The law challenged in Sherbert did not render Saturday worship impossible; it merely exacted a stiff monetary price for observance. Yet RFRA quite clearly contemplates that the burden in cases like Sherbert is substantial. The very concept of a substantiahty test implies a subjective weighing process. Judicial inquiry under a substantiality test must therefore be subjective if courts are to be sensitive to different contexts. Even so, a few guiding principles can be discerned.

First, to the extent possible, the substantiality inquiry should not turn on the centrality or importance of the burdened practice to the religion. To decide whether a particular practice is of central importance to a faith would require a religious judgment, which secular courts are ill-equipped to render. ${ }^{186}$ The threshold question ought to be whether the claimant has a bona fide religious belief that she should engage in the burdened practice. ${ }^{187}$

873, 876-77 (9th Cir. 1993) (holding that O'Lone and Friedman survive Smith). RFRA includes no express exception for the religious rights of prisoners and, thus, may provide greater protection than O'Lone. See Conkle, supra note I57, at 72 \& n.I64 (noting that RFRA's legislative history indicates an intent to overrule $O^{\prime}$ 'Lone); $c f$. Francis v. Keane, 888 F. Supp. 568, 574-76 (S.D.N.Y. 1995) (applying RFRA strict scrutiny to Rastafarian prison guards' claim for an exemption from prison regulations prohibiting dreadlocks).

186 See, e.g., Frazee v. Illinois Dep't of Employment Sec., 489 U.S. 829, 834 (rg89) (holding that a professed Christian's sincerely held religious objection to Sunday work was entitled to First Amendment protection although he was not a member of any organized sect that forbade it); see also Paulsen, supra note $I 62$, at 249 ("Religious freedom claims . . require Government to sort out bona fide free exercise of religion claims from false ones of simple resistance to bureaucracy ... without violating other constitutional principles forbidding Government discrimination among religious beliefs or Government evaluation of the truth, worth, consistency, or plausibility of asserted religious beliefs.").

187 In emphasizing that courts should not assess the validity of a religious belief, the Supreme Court has clearly imphed that the threshold question must be the existence of a religious belief. See Hobbie v. Unemployment Appeals Comm'n of Fla., 480 U.S. 136, r44 n.9 (r987) ("In applying the Free Exercise Clause, courts may not inquire into the truth, validity or reasonableness of a claimant's religious beliefs." (citing United States v. Ballard, 322 U.S. 78, 87 (1944))); Thomas v. Review Bd. of Ind. Employment Sec. Div., 450 U.S. 707, 714-16 (1981). On one view, RFRA's legislative history shows an intent to apply strict scrutiny to substantially burdened conduct that is "motivated" by, as opposed to "compelled" by religion. See Laycock \& Thomas, supra note 162, at 23I-32 \& n.r.3r. As a matter of legislative intent, this may be correct, but I suspect that courts 
Second, in determining whether a generally applicable provision of law substantially burdens a religious practice, the notion of alternative means will be useful if applied flexibly rather than by strict analogy to free speech cases. Consider for example, the statute at issue in Sherbert, which deemed persons unwilling to work on Saturday ineligible for unemployment insurance benefits. Does it create a substantial burden? Courts' analysis might turn on whether the dismissed employees have adequate alternative einployment opportunities that would not require Saturday work. If so, then if claimants do not avail themselves of these opportunities, the state may demonstrate voluntary unemployment without triggering heightened scrutiny under RFRA. Here, courts would focus on claimants' choice of employers, a choice that has no religious significance in itself.

Third, in some cases we may reduce the inevitable subjectivity of the substantiality inquiry by applying the notion of neutrality, but with greater sensitivity than the Smith Court itself did. As Micliael McConnell argnes, the unemployment scheme in Sherbert is hardly neutral, because it reflects the majority's religious preference for Sunday as a day of rest. ${ }^{188}$ By asking whether the burden imposed by a particular law on an adherent of a minority faith greatly exceeds the law's effect on the majority - whose religious preferences the law reflects - we can give the substantiality test some concrete substance.

Although courts may not be prepared to find outright discrimination in disproportionate burdens, the mequality of burdens could still serve as a rough proxy for substantiality. To determine the substantiality of the burden that a law imposes on a religion, it will often be useful to compare that burden with the law's effect on persons wlio do not share the religion of the person challenging the law. In Braunfield v. Brown, ${ }^{189}$ Orthodox Jews challenged a Sunday closing law, in part because it burdened their right to observe the Saturday Sabbath by requiring Jewish-owned stores to remain closed for two days rather than one. 190 In such a case, a court could examine the unequal character of the burden imposed by the challenged law ratler than attempt to conduct a detailed economic inquiry to determine the harm caused to Orthodox Jewish busmesses. It would be sufficient to note that the combined impact of the legal and religious obligations on a Saturday

concerned about floodgate problems will nonetheless use a higher threshold, one that requires the claimant to show that she felt some religious obligation, although not necessarily compulsion. The test that I suggest in the text, which asks what the claimant believes that she "should" do, is deliberately flexible on this point.

188 See McConnell, supra note 14 , at Ir33-36.

189366 U.S. 599 (196r).

190 See id. at 6or. The Court upheld the Sunday closing law. See id. at 609. 
Sabbath observer is much more severe than the corresponding impact on Sunday Sabbath observers and nonobservers. ${ }^{191}$

The difficulty with this approach to RFRA is largely textual. In legislatively overruling $S$ mith, Congress did not expressly disturb the Smith Court's largely formal conception of neutrahty. Instead, Congress extended strict scrutiny to substantial burdens imposed by generally apphicable laws without regard to the laws' comparative effects on persons of different rehigions. Presumably, when a law qualifies as neutral in the $S$ mith sense but not in the more demanding sense that I have described here, RFRA could still be interpreted to require a threshold inquiry imto how substantially the law burdens religion. Perhaps the courts will take a less textualist and more purposive approach to the RFRA, understanding it to reflect general congressional disapproval of Smith and its conception of neutrality. Or perhaps the Supreme Court will, as a constitutional matter, revisit the Smith Court's view of neutrahty quite apart from RFRA. ${ }^{192}$

Barring either of these interpretive maneuvers, ${ }^{193}$ courts will be faced with the task of determining what burdens on religion are sub-

191 Cf. McConnell, supra note 14 , at I134-35 (noting that the laws prohibiting the use of hallucinogenic drugs but not alcohol reflect the fact that Christians and Jews use only the latter in their religious rituals). Note, however, that the creation of an exemption for a Saturday Sabbath observer may, under certain circumstances, place her in a better position than non-Saturday Sabbath observers. Cf. Estate of Thornton v. Caldor, 472 U.S. 703, 710-1I (I985) (finding an Establishment Clause violation when a state statute categorically prohibited employers from discharging an employee for refusing to work on a day designated by the employee as his sahbath). For example, assume that there are five shoe stores in a community with a mandatory Sunday closing law. Four of the stores are owned by Sunday worshippers or nonreligious people. The fifth is owned by an Orthodox Jew. Granting the Orthodox Jew an exemption from the Sunday closing law has the effect of making his store the only store open on Sunday. The other four merchants must divide the Saturday shoe business four ways, however. Although this may seem unfair, the unfairness results primarily from the fact that the majority is permitted to enact a general law requiring Sunday closing - not from the exemption. See McGowan v. Maryland, 366 U.S. 420, 449 (I96I) (rejecting an Establishment Clause challenge to a Sunday closing law). Absent the Sunday closing law, the Saturday Sabbath observers would close their stores on Saturday, Sunday Sabbath observers would close their stores on Sunday, and nonobservers would keep their stores open or closed as they saw fit.

192 Cf. Eisgruber \& Sager, supra note 153, at 1297-98, I306-07 (disapproving of the RFRA approach and advocating instead a principle of "equal regard," arguing that "[g]overnmental action that betrays a failure to treat the serious concerns of minority religious believers with the same regard extended to the deep concerns of citizens generally is vulnerable to a distinct constitutional objection").

193 A reexamination of the concept of neutrality in religion cases seems unlikely in light of the Court's recent willingness to find that, notwithstanding the Establishment Clause, the Free Speech Clause does not permit exclusion of religious groups from various government programs, because such programs provide mere incidental benefits to religion. See Rosenberger v. Rector of Univ. of Va., II5 S. Ct. 2510, 2523-24 (1995) (requiring funding for production of sectarian student newspaper); Capitol Square Review \& Advisory Bd. v. Pinnette, I I5 S. Ct. 2440, 2447 (I995) (requiring that a private group be permitted to place a Latin cross in a plaza next to the state capitol); Lamb's Chapel v. Center Moriches Union Free Sch. Dist., II3 S. Ct. 2141, 2148 (1993) (requiring that a private group be permitted to show a religiously oriented film series in a public school). 
stantial under RFRA. As in the free speech context, it will be difficult to set forth with precision general criteria for making this determination, ${ }^{194}$ which essentially amounts to one of fact-specific linedrawing. ${ }^{195}$

\section{Incidental Burdens on the Unenumerated Right to Privacy}

One of the most important constitutional decisions in recent years, Planned Parenthood v. Casey, ${ }^{196}$ announces a standard for judging the constitutionality of abortion regulations that closely mirrors the standard that I argue should (and largely does) apply to laws incidentally burdening free speecl and free exercise of religion. According to the pivotal three-Justice opinion im Casey, a law that has "the purpose or effect of placing a substantial obstacle im the path of a woman seeking an abortion of a nonviable fetus" constitutes an undue (and therefore unconstitutional) burden on a woman's right to decide whether to have an abortion. ${ }^{197}$

194 In applying a substantiality threshold, the Eighth Circuit stated:

To show a free exercise violation, a religious adherent must initially prove the challenged governmental action substantially burdens the adherent's religious practice. ... [T] den must rise to the level of pressuring the adherent to commit an act the religion forbids, or preventing the adherent from engaging in conduct that the faith requires.

Brown v. Polk County, 37 F.3 404, 4IO (8th Cir. I994). This formulation does not include protection for acts that are merely motivated by - as opposed to compelled by - religion. However, as to acts compelled by religion, the court does not provide any additional guidance, deferring to the district court's discretion in making factual findings. The question remains: how much pressure must the governmental action place on the religious adherent? Note also that in Polk County the challenged action - an order that a government employee stop proselytizing and remove religious symbols from work - was targeted at religion. See id. at 407. Nonetheless, the court applied a substantiality threshold, although it did not rely on or even mention RFRA. In contrast, the Third Circuit - which did invoke RFRA — has held that the Act's substantiality threshold does not apply to targeted burdens. See Brown v. Maliaffey, 35 F.3d 846, 849-50 (3rd Cir. I994).

195 In Rosenberger, Justice Souter observed in dissent that no one argues that all incidental benefits would be Establishment Clause violations:

Would it be wrong to put out fires in burning churches, wrong to pay the bus fares of students on the way to parochial schools, wrong to allow a grantee of special education funds to spend them at a religious college? These are the questions that call for drawing lines .....

Rosenberger, II5 S. Ct. at 254 I (Souter, J., dissenting).

196505 U.S. 833 (1992).

197 Id. at 877 (joint opimion of $\mathrm{O}^{\prime}$ Connor, Kennedy \& Souter, JJ.) (emphasis added). The undue burden standard is binding on lower courts, see Marks v. United States, 430 U.S. 188, 193 (r977) (defiming the holding of a divided Court as the view of the members of the Court who concurred on the narrowest grounds), although for stare decisis purposes, only the portion of the three-Justice opinion that garnered five votes counts as a full-fledged precedent in the Supreme Court itself, see Michael C. Dorf, Prediction and the Rule of Law, 42 UCLA L. REv. 65I, 684-85 (1995). At least for the short term, however, lower courts must muddle through with the undue burden test, because the Supreme Court appears to be uninterested in granting review to flesh out the standard's meaning. See, e.g., Barnes v. Mississippi, 992 F.2d 1335, 1337 (5th Cir.) (upholding a restrictive abortion statute post-Casey), cert. denied, II4 S. Ct. 468 (I993). 
Here we see a standard that appears to work in a familiar fashion. A court will imvalidate a generally valid law as applied to abortion or to some women seeking abortions, but only if the law imposes a substantial burden on the abortion right. ${ }^{198}$ Yet the Casey test states that the substantiality threshold applies to laws with the purpose or effect of burdening a right; Justices O'Connor, Kennedy, and Souter do not distinguish between direct and incidental burdens.

Casey was not the first unenumerated rights case to employ a substantiality thresliold for all burdens. ${ }^{199}$ In Zablocki v. Redhail, ${ }^{200}$ for example, the Supreme Court sustained a challenge to a Wisconsin statute that required a noncustodial parent under a duty of child support to obtain a court's permission to marry. ${ }^{201}$ The Court began its analysis by recoguizing that marriage is a fundamental right. ${ }^{202}$ The Court went on to state that this principle did not render all regulations of marriage suspect:

By reaffirming the fundamental character of the right to marry, we do not inean to suggest that every state regulation which relates in any way to the incidents of or prerequisites for marriage must be subjected to rigorous scrutiny. To the contrary, reasonable regulations that do not significantly interfere with decisions to enter into the marital relationship may legitimately be imposed. ${ }^{203}$

This language closely parallels that of the undue burden standard of Casey. ${ }^{204}$ Therefore, the Casey standard is not anomalous in the Court's privacy doctrine. ${ }^{205}$

198 In one respect, this standard is more strict even than the standard under RFRA. A substantial burden on religion may be upheld under RFRA if it survives strict scrutiny. Under the Casey approach, however, a substantial burden is, ipso facto, unconstitutional. See Casey, 505 U.S. at 877 (joint opinion of O'Connor, Kennedy \& Souter, JJ.). This result appears to follow from the Court's view that the only arguably compelling government interest in the previability abortion context - the life or potential life of a fetus - is insufficient to overcome a woman's right to choose. Cf. Roe v. Wade, 410 U.S. $1_{13}, \mathrm{I6}_{3}-64$ (1973) (describing viability as the stage of development at which the state interest in fetal life becomes compelling). Whether some other state interest might justify prohibiting previability abortions is a question unlikely to arise, because the Court has already held that the other interest typically at stake - the woman's health - does not justify abortion prohibitions at that stage. See id. at I63.

199 See generally Alan Brownstein, How Rights Are Infringed: The Role of Undue Burden Analysis in Constitutional Doctrine, 45 HASTINGS L.J. 867, 872 (1994) (arguing that the undue burden standard of Casey is broadly consistent with the Supreme Court's fundamental rights jurisprudence in a wide range of cases).

200434 U.S. 374 (1978).

201 See id. at $390-91$.

202 See id. at 383-86. The Court deemed marriage a fundamental right for equal protection purposes, but it relied on substantive due process cases. See $i d$. at 384 .

203 Id. at 386 (citing Califano v. Jobst, 434 U.S. 47 (1977)).

204 See Brownstein, supra note 199 , at 895-96 (describing Zablocki as an antecedent of Casey).

205 Moreover, since Casey, at least one district court has applied the undue burden standard to invalidate regulations burdening a different unenumerated right protected under the rubric of a right of privacy: the asserted right to physician-assisted suicide. See Compassion in Dying v. Washington, 850 F. Supp. 1454, 1459-61 (W.D. Wash. 1994), affd, No. 94-35534, I996 WL 94848, 
The doctrinal approach to privacy rights thus appears to differ significantly from the approach to free speech and (statutory) free exercise. In contrast to the latter two areas, it seems that both incidental and direct burdens on privacy rights must be substantial before courts will subject them to heightened scrutiny. Nevertheless, in the remainder of this section, I argue that the conception of incidental burdens underlying the joint opinion in Casey shares significant features with the conception of imcidental burdens on free speech and free exercise, and that understanding Casey will illuminate the general problem of incidental burdens.

Casey does not at first appear to be a case about imcidental burdens at all, because the challenged Pennsylvania statute directly targeted abortion, and only abortion, for regulation. Without invoking incidental burdens, however, it is nearly impossible to make sense of siguificant portions of the pivotal joimt opmion. ${ }^{206}$

In explaining the undue burden standard, the authors of the Casey joint opinion termed regulations falling short of the substantiahty threshold "incidental" burdens. ${ }^{207}$ The termmology is confusing. The opposite of a substantial burden is an insubstantial burden, not an imcidental one. An incidental effect may constitute a substantial burden - for example, a law requiring the concurrence of two doctors before any surgery is performed may not target abortion but does make obtaining an abortion extremely difficult im regions where doctors who perform abortions are scarce. ${ }^{208}$ Conversely, a direct burden may be insubstantial - for example, a one-penny tax on abortions but not other medical procedures. ${ }^{209}$ Why then, does the joint opinion refer to less-than-substantial burdens as incidental? Is there any sense in which a law that imposes requirements on women who wish to obtain abortions but not other medical services constitutes only an incidental restriction on the abortion right?

at *5 (9th Cir. Mar. 6, I996) (en banc). In its opinion, the Ninth Circuit en banc panel suggested that recent Supreme Court doctrine appears to be moving towards a "balancing test" for all infringements of fundamental rights. Compassion in Dying v. Washington, No. 94-35534, I996 WL 94848, at * II (gth Cir. Mar. 6, I996) (en banc). But cf. People v. Kevorkian, 527 N.W.2d 714, 724-33 (Mich. 1994) (finding no right to assisted suicide), cert. denied, II5 S. Ct. I795 (I995).

206 See Gillian E. Metzger, Note, Unburdening the Undue Burden Standard: Orienting Casey in Constitutional Jurisprudence, 94 CoLUM. L. REv. 2025, 203I-38 (1994) (discussing ambiguities in the Casey joint opinion's description and use of the undue burden test); $c f$. Brownstein, supra note 199, at 927-28 (arguing that the Casey joint opinion does not adequately justify the particular version of the undue burden test that it adopts).

207 See Planned Parenthood v. Casey, 505 U.S. 833, 843 (I992) (joint opinion of O'Connor, Kennedy \& Souter, JJ.).

208 See Dorf, suppra note $\mathrm{I}$, at 275 (arguing that such a "Second Opinion Act" might survive a facial attack but could be vulnerable to an as-applied challenge in the case of abortion).

209 See Casey, 505 U.S. at 988 (Scalia, J., concurring in the judgment in part and dissenting in part) (noting that the burdens that the Pennsylvania law placed on abortion were all directed at abortion and were therefore not incidental constraints); Dorf, supra note 1 , at 275 n.x76 (agreeing with Justice Scalia's characterization). 
We can begin to answer this question by identifying the value of the right to decide whether to have an abortion from the perspective of the rightholder. A pregnant woman seeking an abortion has two principal imterests: an interest in not becoming a parent, and an interest in not undergoing the physical privations of pregnancy and childbirth. ${ }^{210}$ On virtually no account of abortion rights does a woman claim an interest in killing a fetus simply for the sake of killing. ${ }^{211}$ However, a pregnant woman's decision to end her pregnancy prior to viability will inevitably have the collateral effect of killing a fetus.

The state's principal imterest, on the other hand, is to protect the potentiality of human life, according to the theory of Roe v. Wade $e^{212}$ and Casey. The state does not directly target the two interests of abortion-seeking women. For the state to preserve fetal life, however, it must impose an incidental burden on the woman's interests in avoiding parenthood and the contimuation of her pregnancy - incidental because the state would theoretically permit her to terminate her pregnancy before gestation became complete were that consistent with preserving fetal life.

The difficulty with this double-faceted view of interests is that, if apphed generally, it would convert nearly all direct regulations of rights into incidental burdens, because typically, what renders the exercise of a right offensive to the majority has little to do with what renders the right valuable to the rightholder. Consider, for example, the rule prohibiting "First Amendinent activities" in the Los Angeles airport, which was invalidated in Board of Airport Commissioners $v$. Jewe for Jesus, Inc. ${ }^{213}$ The airport authorities were concerned about the disruptive potential of "nonairport-related speech."214 The persons challenging the law, however, did not wish to speak for the purpose of disrupting airport activities. Rather, they wished to communicate. ${ }^{215}$ The airport authorities might have argued that their interest in avoiding a disruption of airport activities imposed only an incidental burden on the rights of speakers. Yet such an argument, if accepted, would

210 The Casey majority recognized both interests by locating the abortion right at the crossroads of cases involving intimate associations and cases involving bodily integrity. See Casey, 505 U.S. at 857. Note that a pregnant woman also could be said to have a third interest - that of decisional autonomy or privacy. But an interest defined at such a general level is typically contentless. See TribE, supra note $5, \S$ 15-1, at 1303 .

211 Of course, from the perspective of an abortion opponent, this is precisely what the pregnant woman claims. But this is hardly what justifies the right from the perspective of the woman seeking an abortion. Cf. Kent Greenawalt, Religious Convictions and Political Choice 120 (I988) ("Some people sincerely regard . . . abortions . . . as murders; others see them as exercises of a fundamental human right. The level of mutual understanding is very low . . . ").

212410 U.S. II3 (1973).

213482 U.S. 569 (1987).

214 Id. at 576.

215 The plaintiff was a religious organization that sought to distribute leaflets within an airport terminal. See id. at $57 \mathrm{I}$. 
nearly eviscerate judicial protection of rights, because it is usually possible to characterize the harm that a right's exercise causes in a way that does not target the right's value from the perspective of the rightholder.

Nonetheless, the Supreme Court has sometimes accepted a more hinited version of this argument. In City of Renton v. Playtime Theatres, Inc. ${ }^{216}$ the Court upheld a zoning ordinance that prohibited theaters from showing nonobscene films that emphasized specific sexual activities or anatomical areas. ${ }^{217}$ Despite the ordinance's facial use of expressive content as the trigger for regulation, the Court characterized the ordinance as content-neutral because it was justified not by hostility to the content of the restricted films, but by the "secondary effects" of adult theaters on the community - increased prostitution and other illegal conduct. ${ }^{218}$ The Court has not always confined this conception of content-based regulation to low-value speech, but has sometimes incorporated it into more general free speech jurisprudence. ${ }^{219}$ Indeed, the Court often defines a content-neutral regulation of speech as one that is justified in terms of communicative impact, 220 and thereby prescribes a double-faceted view of interests similar to that used in Casey.

The parallel between the Renton conception of content-neutral regulations and Casey's premise that some laws targeting abortion nonetheless pose only an imcidental burden is not perfect. First, under the Court's free speech jurisprudence, even a content-neutral regulation of speech such as the ordinance in Renton must satisfy the O'Brien test.221 Under Casey, in contrast, an incidental burden that is not a substantial obstacle need only be reasonable, ${ }^{222}$ which is presumably a lower standard. ${ }^{223}$

More importantly, the relation in Renton of the secondary effects of adult films to the messages of those films differs from the relation in Casey of the state's interest to the woman's interest. In the Renton context, real situations exist in which the secondary effects do not ac-

216475 U.S. 4 I (1986).

217 See id. at 44 .

218 See id. at $47-48$.

219 See Boos v. Barry, 485 U.S. 3I2, 320-2I (Ig88) (approving the Renton test of contentneutral speech in the context of political speech but finding it inapplicable to the ordinance in question).

220 See, e.g., Ward v. Rock Against Racism, 491 U.S. 781, 791 (1989).

221 See Renton, 475 U.S. at $47-48$.

222 See Planned Parenthood v. Casey, 505 U.S. 833, 872-74, 883 (joint opinion of O'Connor, Kennedy \& Souter, JJ.); see also Parks v. City of Warner Robins, 43 F.3d 609, 614-15 (IIth Cir. I995) (relying on Zablocki and applying rational basis scrutiny to municipal anti-nepotism policy because it "does not directly and substantially interfere with the fundamental right to marry").

223 According to one commentator, Casey thus adopts a two-tier approach for abortion regulations, whereas free speech doctrine employs a three-tier approach. See Brownstein, supra note 199, at 926 . 
company the films. ${ }^{224}$ In contrast, a woman claiming a right to an abortion challenges the state's view that its interest in preserving fetal life can be described apart from - and in opposition to - her interests. In practical terms, if an abortion regulation based on the state's asserted mterest in preserving fetal life imposes only an incidental burden on the woman's rights to avoid continuing pregnancy, childbirth, and parenthood, then even an outright ban on abortions would impose only an mcidental burden, so long as the ban is justified by an interest in fetal hife. But then all burdens engendered by abortion regulations would be incidental, a position clearly at odds with the Casey plurality's approach.

Is there a meaningful sense in which abortion restrictions do not have the purpose of making the abortion right more difficult to exercise? If one looks not so much to the underlying basis for the abortion right but to its content, then we may find the beginnings of an explanation. According to the Casey joint opinion, the right recognized by Roe is a "right to make the ultimate decision, not a right to be insulated from all others in doing so."225 Under this view, a twenty-fourhour waiting period durmg which a woman may consult others and reflect on the information that the state has required her to consider does not regulate the ultimate decision, even though it obviously targets the decisional process. Such a regulation facilitates what the

224 I do not wish to endorse the application of the Renton approach in cases such as Renton itself. If the "secondary effects" that concern the government derive from the communicative impact of speech, then the test has the potential to swallow free speech law whole. See supra pp. I222-23. A shightly less problematic version of the secondary effects rationale appears in Justice Souter's opinion in Barnes v. Glen Theatre, Inc., 50I U.S. 560, $58 \mathrm{I}-87$ (1991) (Souter, J., concurring in the judgment), in which the majority upheld a prohibition on public nudity as applied to nude dancing, see Barnes, 5or U.S. at 563. He suggested that secondary effects are only secondary if they are not mediated by the communicative impact of the expressive conduct. According to Justice Souter, the state is entitled to conclude that the people who come to watch nude dancing are either more inclined to commit sexual assault and to patronize prostitutes than other members of the public, or are spurred to crime by the viewing of nude bodies, quite apart from any message that they receive from the nude dancing. See id. at 585-86 (Souter, J., concurring in the judgment). But see Vincent Blasi, Six Conservatives in Search of the First Amendment: The Revealing Case of Nude Dancing, 33 WM. \& MARY L. Rev. 6Ir, 654-55 (1992) (noting Justice Souter's failure to provide any empirical evidence for these propositions). Assuming that Justice Souter's hypothesis is factually correct and assuming that one can distinguish between effects associated with speech and effects caused by speech, Justice Souter's version of the secondary effects rationale is less sweeping than the Renton formulation appears to be.

In any event, outside the context of low-value speech cases, the Court has tended to disregard the Renton and Ward definition of content-neutrality in recent years, instead reaffirming the view that "illicit legislative intent is not the sine qua non of a violation of the First Amendment." Turner Broadcasting Sys., Inc. v. FCC, II4 S. Ct. 2445, 2459 (1994) (quoting Simon \& Schuster, Inc. v. New York State Crime Victims Bd., 502 U.S. ro5, 117 (I99I) (quoting Minneapolis Star \& Tribune Co. v. Minnesota Comm'r of Revenue, 460 U.S. 575 , 592 (r983)) (internal quotation marks omitted); see Bhagwat, supra note II3, at I6I-62.

225 Casey, 505 U.S. at 877 (joint opinion of O'Connor, Kennedy \& Souter, JJ.). 
state perceives to be informed decisionmaking, and is therefore consistent with the woman's right to make the ultimate decision. ${ }^{226}$

To some, calling the twenty-four-hour waiting period a measure that facilitates the abortion decision may seem Orwellian, because in many cases the waiting period operates to frustrate that decision by rendering more costly and time-consuming the process for obtaining an abortion by a woman who has already made her decision. The Casey jomt opinion authors might respond that, because the abortion decision is irreversible, measures that induce informed and careful thought are needed to facilitate decisions that will not lead to later regret. But this response seems inadequate. If the state's true concern is irreversibility, why not enact a general law governing all irreversible medical decisions? ${ }^{227}$ There must be some reason to believe that the substance of a particular irreversible decision carries special risks. In the abortion context, it may be that the state deems the destruction of a fetus sufficiently harmful to justify the added dehiberation. But then does this rationale directly undermine the abortion right itself?

Perhaps the state may invoke the reasons for recognizmg a right to abortion $\mathrm{m}$ the first place. Some rights are protected because they are important to the individuals who exercise them as well as to society generally. Free speech is an example of such a right. Although many persons will use their right of free speech to the net detriment of society, most defenders of the right will agree that, in the aggregate, society is better off when there is a robust marketplace of ideas. In contrast, many supporters of privacy rights may believe that acts such as abortion - and, for that matter, suicide - are almost always regrettable, but that, nonetheless, society as a whole should not have the power to use government to dictate whether an abortion may or inay not be performed in a particular case. This does not mean, however, that the state may not discourage the protected, though disapproved act. As Ronald Dworkin puts it, there are valid reasons why government may "aim that its citizens treat decisions about human life and death as matters of serious moral importance,"228 and thus that "[i]t is perfectly consistent to insist that states have no power to impose on their citizens a particular view of how and why life is sacred, and yet

226 See id. at 872 ("[T]he State may enact rules and regulations designed to encourage [a woman] to know that there are philosophic and social arguments of great weight that can be brought to bear in favor of continuing the pregnancy . . . .").

227 Indeed, why stop at medical decisions? All decisions are, in some sense, irreversible. For example, the decision to burn an American flag in public as an act of political expression will affect the flag burner's standing in the community in ways that probably can never be undone. Yet this would not be a sufficient basis for imposing a 24-hour waiting period on persons who desire to burn a flag.

228 RONALD DWORKIN, LIFE's DOMINION I5I (I993). 
also to insist that states do have the power to encourage their citizens to treat the question of abortion seriously." 229

The Court appears to be receptive to a variety of arguments aimed at showing that regulations that fall short of prohibition do not count as purposeful imfringements of the abortion right, because given the way that the right is conceptualized, the regulatory purpose is not to frustrate the exercise of the right - even if that result is the effect in some set of cases. This approach may be generahized beyond abortion. Consider the right to marry at issue in Zablocki and Loving v. Virginia. ${ }^{230}$ We might conceptualize the right to marry as a right of a couple to have their relationship receive legal recognition upon satisfying reasonable, facilitative, state-imposed regulations. On this conception, a state law requiring a blood test or a nominal registration fee would impose only an incidental burden on the right to inarry, because that right, by definition, would only protect against nonfacilitative burdens. ${ }^{231}$ Some laws targeting marriage, and only inarriage, could thus be termed incidental on such a definition.

Casey and Zablocki thus suggest that a constitutional right to do $x$ sometimes means a right to do $x$ free of some, but not all, kinds of burdens on $x$. In the case of abortion, we would say that the right to an abortion means a right to an abortion free from some kinds of burdens, but not free from reasonable health measures or measures designed "to persuade the woman to choose childbirth over abortion."232 In general, therefore, soine rights could presuppose the existence of conditions such that a regulation that appears to burden a right could actually be consistent with the assumptions that define the right.

Yet this approach resembles the conception of rights that I discussed and rejected in Part I. I noted there that it is possible to rig the definition of rights so that incidental burdens do not constitute infrimgements. By redefining a right to do $x$ as a right not to be burdened by a law specifically penalizing the doing of $x$, one could make the mcidental burden problem go away by definitional fiat. Similarly, it inight seem that by redefining a right to do $x$ as a right not to be burdened by some particular class of restrictions on the right to do $x$,

229 Id. at 153 ; see also WeINREB, supra note 78, at 97 ("Rights . . . make us fit for moral judgment; they do not guarantee that we shall act morally.").

230388 U.S. I (1967). The Court invalidated Virginia's anti-miscegenation statute on two alternative grounds: that it utilized a racial classification, see id. at 7-12; and, that it unconstitutionally burdened the fundamental right to marry, see id. at 12 .

231 When applied to an indigent couple, a registration fee might nonetheless be an unconstitutional burden. $C f$. Boddie v. Connecticut, 401 U.S. 37r, 374 (r97r) (invalidating a statute levying court fees against an indigent couple seeking a divorce because the fee deprived them of an opportunity to be heard in court).

232 Planned Parenthood v. Casey, 505 U.S. 833, 878 (joint opinion of O'Connor, Kennedy \& Souter, JJ.). 
we have simply defined away our difficulties for those restrictions not listed in the definition of $x$.

This criticism has some validity, but it does not render all definitional gambits illegitimate. Indeed, unless we are willing to begin with the proposition that people have a general right to do whatever they want, we will need some way to draw boundary lines im defining the scope of the particular rights protected.

To some extent, the boundary will reflect a judginent about the scope of the rightholder's interest. For example, obscenity does not receive First Amendment protection because of a judginent that obscenity does not contribute to the marketplace of ideas or to human self-expression (of the appropriate sort) in the same way that other kinds of speech do. ${ }^{233}$ In other instances, the right's boundary will more clearly reflect the strength of the state's countervailing interest.234 To say, for example, that the right to free speech ends at the point when a breach of the peace is imminent ${ }^{235}$ is simply another way of saying that regulations of this category of speech are permissible.

The two classifications - rights whose boundaries are defined in terms of the rightholder's interests and rights whose boundaries are defined in terms of the state's countervailing interests - are not always cleanly separable. One might favor regulation of obscenity (or pornography) on the view that the benefits that its consumers derive are outweighed by the concrete harm that it causes to others or the moral harm that it inflicts on the consumers themselves. Conversely, one might take the view that speech that constitutes incitement serves none of the values conventionally associated with the First Amendment. Similarly, the right to choose to termimate. a pregnancy (for reasons other than health) ends at fetal viability both because of the increased state interest in a viable fetus and because of a decreased individual imterest on the part of a woman who has waited a long period before deciding to abort. ${ }^{236}$ Internal and external limits often coexist.

233 See Roth v. United States, 354 U.S. 476,484 (I957) (finding obscenity to be "utterly without redeeming social importance").

234 See generally WEINREB, supra note 78, at 74-100 (arguing that the outer boundaries of rights and responsibilities are defined with reference to each other). Even if we do not allow for reasonable restrictions within the definition of a right, such allowance will inevitably be made when we scrutinize infringements of the right. See Brownstein, supra note I99, at $87 \mathrm{I}$ ("[O]ften the Court does not isolate the issue of infringement, but rather implicitly subsumes it within an analysis that focuses on the scope of the right and the state's justification for any purported impairment.").

235 See Brandenburg v. Ohio, 395 U.S. 444, 447 (I969).

236 See Casey, 505 U.S. at 870 (joint opinion of O'Connor, Kennedy \& Souter, JJ.) (reaffirming the viability line both because of the stage of fetal development and because "it might be said that a woman who fails to act before viabihity has consented to the State's intervention on behalf of the developing child"). 
Casey thus illustrates that the classification of a burden as incidental or direct depends in significant part not only on the nature of the burden, but also on the scope of the right, which in turn depends upon the reasons for recognizing the right and for establishing its stopping point. As the First Amendinent analogies illustrate, this point has potential apphicability to all primary conduct rights. ${ }^{237}$

This section has thus far addressed two privacy rights: the right to marriage and the right to abortion. Throughout, I have implicitly assumed that the proper approach to incidental burdens on these rights will also be the proper approach to incidental burdens on other privacy rights. Without exhaustively cataloguing and analyzing all privacy rights, I close this section by sketching the reasons for my assumption and suggesting some of its limitations.

Although the Supreme Court soinetimes eschews expressly characterizing particular unenumerated rights as specific manifestations of a more general right to privacy, ${ }^{238}$ in other cases its rhetoric reveals an underlying commitment to certain unifying themes. For example, in Casey, the opinion for the Court reaffirmed the practice of recognizing unenumerated rights in the following terms:

Our law affords constitutional protection to personal decisions relating to marriage, procreation, contraception, family relationships, child rearing, and education. ... These matters, mvolving the most intimate and personal choices a person may make in a lifetime, choices central to personal dignity and autonomy, are central to the liberty protected by the Fourteenth Amendinent. At the heart of liberty is the right to define one's own concept of existence, of meaning, of the universe, and of the mystery of human life. Beliefs about these matters could not define the attributes of personhood were they formed under compulsion of the State. ${ }^{239}$

The Court quite clearly located the abortion right within a constellation of what it termed "personal" choices. This suggests that the Court envisioned a zone of personal freedom linking a variety of rights. These rights are valuable because they protect inportant interests of the rightholder. Although the Casey Court described the privacy right as a right to make decisions free of compulsion by the state, the Court did not mean that government intrusion into the private realm is an evil in itself. Instead, government intrusion inust be avoided in order to preserve the individual's right to define herself

237 Of course, in Casey itself, the classification of a burden as incidental played no essential role in the Court's decision, given its declaration that the same standard applies to laws with either the purpose or the effect of burdening the abortion right. In the next Part, I consider whether this unitary standard is justifiable; I locate incidental burdens within the larger context of questions about how rights are infringed.

238 See, e.g., Bowers v. Hardwick, 478 U.S. I86, rgo (rg86) (describing the subject matter of unenumerated-rights cases in narrow terms).

239 Casey, 505 U.S. at 85 r. 
autonomously - a right of independent value. Indeed, according to the Court, what makes privacy rights valuable is the very fact that the individual herself chooses how to exercise them.

Thus, the Casey Court's justification of privacy rights fits comfortably within the conception of primary conduct rights that I described in Part I above. In the images of the Anti-Federalists, the Constitution erects walls or barriers to prevent government imtrusion into the private sphere. ${ }^{240}$ In normative terms, private decisionmaking trumps most government programs either as a matter of deontological right or as a result of a consequentialist assessment that persons should be free to pursue their own conception of the good life. As we saw above, ${ }^{241}$ either basis for protecting a realm of right leads naturally to the conclusion that incidental burdens can undermine the right.

Of course, we should not take the Casey Court's understanding of the privacy right as definitive. It may be possible to defend the privacy right in terms that focus inore clearly on impermissible government action rather than on impermissible burdens on individuals. For example, in striking down a ban on contraceptive use as applied to married couples, the seminal modern privacy case, Griswold v. Connecticut, ${ }^{242}$ suggests a rationale based on the limits of government power. ${ }^{243}$ The Court asks rhetorically: "Would we allow the police to search the sacred precincts of marital bedrooms for telltale signs of the use of contraceptives? The very idea is repulsive to the notions of privacy surrounding the marriage relationship."244

However, a government-centered justification of the privacy right is problematic. What renders the governmental intrusion into the marital bedroom repulsive is the underlying judgment that contraceptive use is a private matter. Were the government searching for evidence of an activity that it could lawfully prohibit, such as child abuse, the marital bedroom would not sbield the wrongdoer against a police officer with a valid search warrant. ${ }^{245}$

To put the point another way, attempts to root the privacy right in the birits of government power seem ultimately to rest upon some conception of the value of privacy to individuals. In this respect, consider Jed Rubenfeld's creative suggestion that the right of privacy protects against "a particular kind of creeping totalitarianism."246 The right of privacy shields us against "a society standardized and normal-

240 See supra p. I188.

241 See supra pp. I194-99.

242 38I U.S. 479 (1965).

$243 \mathrm{See}$ id. at $48 \mathrm{r}, 486$.

244 Id. at $485-86$.

245 But cf. Stanley v. Georgia, 394 U.S. 557, 559 ( 1969 ) (holding that the First Amendment prohibits prosecution for private home possession of legally obscene material).

246 Jed Rubenfeld, The Right of Privacy, ro2 HARv. L. REv. 737, 784 (1989). 
ized, in which lives are too substantially or too rigidly directed,"247 Rubenfeld thus would appear to justify the privacy right by reference to a negative or anti-totahtarian vision of the state rather than an affirmative vision of the individual.

Careful examination of Rubenfeld's thesis, however, reveals that it too rests on an affirmative conception of rights that serve individuals' interests. Rubenfeld contends that the Court's privacy decisions do not protect persons in engaging in particular acts or making particular decisions so much as the right of privacy prevents the state from forcing persons into prescribed life patterns. ${ }^{248}$ For example, "[a]nti-abortion laws produce motherhood" and thereby require woinen to play the role of mother. ${ }^{249}$ Such laws are "totalitarian" in the sense that they shape the totahity of a person's life.

Let us assume for the sake of argument that Rubenfeld's justification of the privacy right in "anti-totalitarian" terms is correct. Even so, his account rests on a vision of rights that derive their value from the rightholder's individual interest in rights - a point somewhat obscured by Rubenfeld's confusing use of the term "totalitarian." The "total" in totalitarian ordinarily refers to the aspects of society controlled by the state. Thus, although a state that probibits abortion inay be unjust, if it is a inulti-party democracy that respects other civil hiberties, we would not term the state totahtarian. By conjuring up for us the image of a state that controls all aspects of human life, Rubenfeld ehides the question of what particular aspects of human life the state should be permitted to regulate or even to control.

This question cannot be answered without some conception of what is valuable to the individual - whether we describe value in the conventional terms of what an individual wishes to do or, as Rubenfeld would, in terms of what she wishes to avoid. In concrete terins, how are we to know that a law prohibiting bakery employment for more than ten hours per day or sixty hours per week ${ }^{250}$ does not unacceptably force a person who is subject to the law into a total life pattern - that of a worker with leisure time? The answer can only be a value judgment that avoidance of this kind of life pattern does not warrant special constitutional solicitude. In more conventional terms, modern privacy law assumes that some freedoms have inore value to individuals than others. ${ }^{251}$

In short, the right of privacy protects various freedoms because individuals value them. Deciding which freedoms to protect and de-

247 Id.

248 See id. at $783-84$.

249 Id. at 788.

250 See Lochner v. New York, I98 U.S. 45, 64 (Ig05) (invalidating such a law as an unreasonable interference with the liberty of contract protected by the I4th Amendment).

251 See TRIBE \& DORF, supra note 55, at 66. 
lineating the scope of those freedoms will often call for difficult judgments; yet whatever lines courts draw, the manner in which government actions infringe different privacy rights will exhibit broad similarities because these rights receive recognition for broadly similar reasons. Thus, it is sensible that the same basic framework for assessing incidental burdens apply to all privacy rights. To test this claim, let us consider another privacy case.

In Moore v. City of East Cleveland, ${ }^{252}$ the Supreme Court held unconstitutional a housing ordinance that forbade persons who were not members of the same family from sharing a dwelling unit, and excluded from the definition of "family" a unit comprising two first cousins and their grandmother. Relying on the privacy line of cases, Justice Powell, writing for a plurality, observed that East Cleveland's decision "to regulate the occupancy of its housing by slicing deeply into the family itself" is "no mere incidental result of the ordinance."253 Suppose, however, that a law did impose a mere incidental burden on the right of a self-defined family unit to live together. For concreteness, imagine that a husband, wife, and two minor children wish to live in a section of a city that the municipality has zoned for cominercial use only. The law imposes an incidental burden on their fainilycohabitation right under Moore. How should the incidental burden be addressed?

Under my analysis of Casey's approach to incidental burdens, the city need not satisfy heightened scrutiny unless the law substantially burdens the family's right. Do zoning laws have this effect? As a general matter, it is unlikely that any zoning law would have as severe an impact as the law in Moore did. There, the city forbade Ms. Moore and her grandclildren from living together anywhere in the city. ${ }^{254}$ Still, we can imagime circumstances in which the commercial zoning law would impose a substantial burden. For example, if there is a critical housing shortage in the city, then converting a residential zone to a cominercial zone could have the incidental - and substantial effect of forcing the family outside the city. It would not seem especially mappropriate to require the city to come forward with some good reason for taking an action with such consequences.

Of course, the sympathy that we feel for the uprooted family in the above hypothetical case may not be connected to a violation of its rights under Moore. We would probably be no less sympathetic to an individual who is zoned out of his home or to a group of unrelated persons who are zoned out of their collective home. Yet Moore expressly distinguished the case of unrelated persons. ${ }^{255}$ Should we

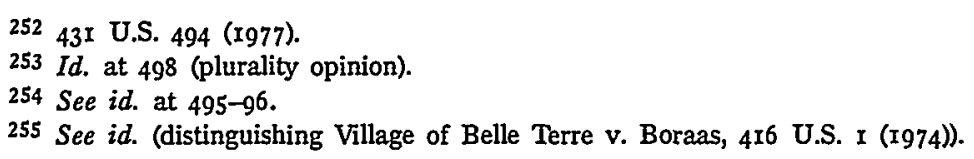


therefore conclude that the incidental burden framework described above does not apply to the Moore group right? That conclusion would be premature, but to avoid it we must, as always, be very clear about the scope of the right at issue.

In the case of the unrelated persons zoned out of their home, Moore suggests that they receive no special constitutional solicitude as a group. But that is a far different thing from saying that they are not entitled to protection as individuals. If the law in Moore had entirely prohibited Ms. Moore from living anywhere in the city, regardless whether she lived alone, with family members, or with unrelated persons, she might have claimed a violation of a right to dwell soinewhere in the city. We might infer that right from the fact that East Cleveland did not defeat Ms. Moore's actual claim by arguing that she could live with her grandchildren outside the city.

In the alternative, we imght prefer to view Moore as a disguised equal protection case. Perhaps there is no right to live in any particular city, but a city policy that permits cohabitation by some kinds of family groups and excludes cohabitation by others must satisfy strict scrutiny. This would be a plausible explanation of the result in Moore, although not the explanation that the Court gave. Reconceptualizing Moore as an equal protection case, however, would seein to suggest that it does not protect a right to primary conduct, and thus the approach to incidental burdens described above would not necessarily apply.

On the assumption that Moore does recognize a substantive right to live with family members, apphication of the general incidental burden framework advanced in this article is sensible. As a specific manifestation of the general right to privacy, the right to live with family members is recognized because it has great value to the rightholder. A law imposing an mcidental burden on the right, if substantial, may deprive her of the right. Thus, subjecting such a law to heightened scrutiny is an appropriate response.

The case for universalizing from the discussion of incidental burdens on the rights to abortion and to marriage is reasonably strong. As a general matter, incidental burdens on privacy rights infringe important interests of rightholders. In the specific case of Moore, we see that the general proposition holds, but we also derive a cautionary note: in order to understand how to respond to an incidental burden, courts must not only be precise about the nature of the burden, but also about the nature of the right.

\section{Implications, Applications, and Limitations}

Although riddled with inconsistencies and exceptions, existing law in the areas of free speech, (statutory) free exercise of religion, and privacy appears to recoguize that an incidental burden on a primary 
conduct right triggers some form of heightened scrutiny if, but only if, the hurden is substantial. In the course of describing this doctrine, I have argued that the substantiality requirement is a sensible response to coinpeting concerns: on the one hand, the best understanding of constitutional text, history, structure, and purpose suggests that incidental burdens matter; on the other hand, for government to function effectively, most incidental burdens must be deemed inoffensive. The substantiality requirement mediates this conflict.

In this final section, I address four questions raised by the discussion above. First, why not require that all burdens on fundamental rights - whether direct or incidental - rise to the level of substantiahty before applying heightened scrutiny? Second, what does the approach to incidental burdens described above imply for the treatment of facial and as-applied challenges to assertedly unconstitutional laws? Third, what difficulties can we expect to encounter in trying to determine what constitutes a substantial burden? Fourth, how can we apply the framework developed for analyzing incidental burdens on primary conduct rights to other types of rights?

\section{A. Application of the Substantiality Threshold to Targeted Burdens}

The joint opinion from Planned Parenthood $v$. Casey ${ }^{256}$ quite clearly states that a law having either the purpose or the effect of erecting a substantial obstacle to a woman's decision whether to have an abortion is unconstitutional. ${ }^{257}$ By implication, a law with the purpose of erecting a minor obstacle to the abortion decision would survive the undue burden test. In other words, the Casey joint opinion implies that the substantiahty threshold applies not only to imcidental, but to direct burdens as well. Is this approach merely sloppy language on the part of the three authors, or does it reflect some underlying jurisprudential insight? ${ }^{258}$

The short answer is a little of each. Plainly, the joint opinion cannot mean that laws having as their principal purpose the frustration of a constitutional right without serving some other substantial interest will be upheld so long as the government's tools only include rela-

256505 U.S. 833 (I992).

257 See id. at $877 \rightarrow 8$ (joint opinion of O'Connor, Kennedy \& Souter, JJ.).

258 Perhaps the suggestion that the substantiality threshold applies even to purposeful burdens reflects the joint opinion authors' uneasiness about recognizing unenumerated rights at all. This explanation seems unlikely, however, because the portion of the joint opinion that conmanded five votes ringingly endorses the recognition of such rights. See Casey, 505 U.S. at 846-52. Moreover, permitting de ninimis but not substantial purposeful burdens is a rather irrational means of narrowing the scope of the abortion right because most efforts to limit abortion will only succeed if they impose substantial burdens. 
tively minor obstacles. ${ }^{259}$ As the Third Circuit explained in holding that the substantiahty threshold of RFRA does not apply to laws that purposefully disadvantage religious practice:

The rare cases which address acts or laws which target religious activity have never limited liability to instances where a "substantial burden" was proved by the plaintiff. Applying such a burden test to non-neutral government actions would make petty harassment of religious institutions and exercise immune from the protection of the First Amendinent. A burden test is only necessary to place logical limits on free exercise rights im relation to laws or actions designed to achieve legitinate, secular purposes. Because government actions intentionally discriminating against religious exercise a fortiori serve no legitimate purpose, no balancing test is necessary to cabin religious exercise im deference to such actions. ${ }^{260}$

Generalizing this approach beyond rehgion clains, we might say that if the apparent purpose of a law is to frustrate tbe exercise of a right, that alone should be sufficient to trigger strict scrutiny. ${ }^{261}$

Of course courts, including the Supreme Court, are understandably reluctant to invahidate a law that could, in principle, serve a valid purpose on the ground that it actually was enacted for an illegitimate reason. ${ }^{262}$ Laws often serve inore than one purpose, and in any event, the purpose of a law enacted by a inulti-inember body may be indeterininate. For this reason, an inquiry into purpose will typically be "objective" in the sense that courts seek to determine what justifications could reasonably underhe a law, rather than what purposes in fact inotivated the relevant governinent actors. ${ }^{263}$

Moreover, I ain not suggesting that courts should scrutinize all laws prescribing general rules of conduct for an underlying illicit purpose. One examines purpose in the hope of saving a law that is targeted at protected conduct, not in the hope of invalidating a law

259 Cf. id. at 919 n.5 (Stevens, J., concurring in part and dissenting in part) (stating that targeted regulation of fundamental rights is permissible but "must be predicated on legitimate state concerns other than disagreement with the choice the individual has made" (quoting Hodgson v. Minnesota, 497 U.S. 417,435 (I990) (opinion of Stevens, J.)) (internal quotation marks omitted)).

260 Brown v. Borough of Mahaffey, 35 F.3d 846, 849-50 (3rd Cir. I994) (internal citations omitted).

261 See, e.g., Metzger, supre note 206, at 2078-79 (arguing that laws that have the purpose of impeding access to abortion ought to be invalid per se).

262 See Palmer v. Thompson, 403 U.S. 217, 224 (I97I); United States v. O'Brien, 39I U.S. 367 , 382-86 (r968). But see Miller v. Johnson, II5 S. Ct. 2475, 2488 (I995) (concluding that, in order to prevail on an equal protection challenge to a voting district, "plaintiff's burden is to show, either through circumstantial evidence of a district's shape and demographics or more direct evidence going to legislative purpose, that race was the predominant factor motivating the legislature's decision to place a significant number of voters within or without a particular district"); Edwards v. Aguillard, 482 U.S. 578, 586-89 (1987) (holding Louisiana's "Creationism Act" violative of the Establishment Clause because it lacked a clear secular purpose).

263 Cf. Pildes, supra note 32, at 729 n.45 (arguing that the literature exploring the indeterminacy of legislative purpose in constitutional law often mistakenly focuses on "the subjective states of mind of public actors"). 
that appears to be innocuous. Thus, I agree with Laurence Tribe, who counsels:

[I] $f$ a government-enacted rule of conduct is constitutionally inoffensive both on its face and as applied to the particular individual challenging it, the fact that the rule would not have been promulgated ... but for the enacting body's desire to achieve a constitutionally forbidden result tells us nothing more than that the government body engaged in an unsuccessful attempt to violate the Constitution. ${ }^{264}$

But when a law that does single out protected conduct appears to have as a primary purpose the frustration of the exercise of a right, strict scrutiny is appropriate to determine whether there is a suffciently close fit between the law and the asserted compelling interest it serves; if not, then it is a fair inference that the law's principal purpose is the illegitimate one of frustrating the exercise of a right. ${ }^{265}$

Although the Casey joint opinion was wrong to suggest that even purposeful barriers to the exercise of a constitutional right must be substantial in order to be invahd, the suggestion may still have value if we assume that by purposeful restrictions the joint opinion really meant only targeted regulations. A targeted regulation apphes only to exercises of a right (such as abortion), but is not necessarily designed for the purpose of frustrating its exercise. As Justice Powell pointed out in his Zablocki v. Redhail ${ }^{266}$ concurrence, most regulations of marriage will be targeted but nonpurposeful. ${ }^{267}$ A few hypothetical examples will further illustrate the sense in which I mean the distinction between targeted regulations and purposeful restrictions.

Suppose that there is a constitutional right to physician-assisted suicide. 268 Consider the three following regulations. First, every person must seek the advice of at least two physicians before undertaking any nonreversible course of medical treatment (Regulation A). This regulation imposes an incidental burden on the assuned right to physicianassisted suicide. My synthesis of existing doctrine requires that some

264 Tribe, supra note 27 , at 23.

265 Cf. City of Richmond v. J.A. Croson Co., 488 U.S. 469,493 (Ig8g) (O'Connor, J., for a plurality) (observing that the goal of strict scrutiny is to "smoke out" ilicit governmental purposes (internal quotation marks omitted)).

266434 U.S. 374 (1978).

267 See id. at 397-99 (Powell, J., concurring).

268 See Compassion in Dying v. Washington, No. 94-35534, 1996 WL 94848, at *I (9th Cir. Mar. 6, r996) (en banc) (invalidating a state law prohibiting assisted suicide as applied to doctors seeking to aid competent, terminally ill adult patients); of. Cruzan v. Director, Mo. Dep't of Health, 497 U.S. 26r, 278-79 ( 1990 ) (assuming arguendo the right of a competent patient to refuse life-saving food and water). Note that Justice O'Connor, who provided a crucial vote in Cruzan, would have held that a competent patient has a right to refuse medical treatment. See id. at 287-92 (O'Connor, J., concurring). Thus, five Justices were prepared to recognize a limited substantive right to die. Those who think either that Cruzan cannot be stretched this far or that, if it can be, it would be an erroneous interpretation of the Constitution, might wish to imagine for the sake of this example that there is an explicit constitutional amendment protecting "the right to physician-assisted suicide." 
form of heightened scrutiny be satisfied if, but only if, the burden is substantial. The test used to determine substantiality slould, as in the context of free speech and statutory free exercise, include an assessment of the rightholder's alternative means of exercising the right and should use a baseline that is neutral in more than the sense ${ }^{269}$ from Employment Division v. Smith. ${ }^{270}$

Second, every person wishing to have the assistance of a physician in committing suicide must first consult with a licensed psychiatrist who certifies that the person both is mentally competent and wishes sincerely to commit suicide after carefully considering the ramifications and alternatives (Regulation B). ${ }^{271}$ The hurden on the riglit to pliysician-assisted suicide imposed by this regulation is not incidental in the usual sense. The law singles out protected conduct for special regulation; it is thus targeted at the right. The apparent purpose of the law, however, is not to frustrate the exercise of the right to physician-assisted suicide. Rather, Regulation B appears to facilitate the exercise of the right in the same way that the authors of the Casey joint opinion believed that some provisions of the Pennsylvania Abortion Control Act facilitated the abortion decision. ${ }^{272}$ Regulation $\mathrm{B}$, then, aims at ensuring that the right to physician-assisted suicide is exercised responsibly, and it arguably addresses the autonomy concerns that underlie the suicide right. ${ }^{273}$

Third, every person wishing to have the assistance of a physician in committing suicide must first forfeit all of his or her assets to the state (Regulation C). This regulation in no way facilitates the individual's choice whether to commit physician-assisted suicide. The regulation not only targets the right, but also affirmatively punishes those who exercise it. Note tliat in practice, Regulation C may impose a quite insubstantial burden. A person wlio wishes to avoid disinheriting his or her heirs might circumvent Regulation $\mathrm{C}$ through an irrevocable inter vivos gift prior to the suicide. Thus, if the substantiality threshold applied to purposeful restrictions of this sort, Regulation C would escape heightened scrutiny (assuming that the expedient of such

269 See supra pp. $1215-18$.
270494 U.S. 872 (1990).

271 Persons with experience in mental health law may worry that mental health professionals would virtually never be willing to make the appropriate findings due to fear of liability. Perhaps a rule of immumity would alleviate such a concern.

272 See Planned Parenthood v. Casey, 505 U.S. 833, 883 (1992) (joint opinion of O'Connor, Kennedy \& Souter, JJ.).

273 Targeted, nonpurposeful regulations will not always facilitate the exercise of a right. For example, consider: every person wishing to have the assistance of a physician in committing suicide must first write a will (Regulation B'). This regulation protects the welfare of the surviving family members of the person who commits suicide - an interest that does not reflect government hostility to the right. It is thus targeted but nonpurposeful. Regulation $\mathrm{B}^{\prime}$ is not necessarily facilitative, lowever, because it directly regulates neither the decision whether to exercise the right nor the right itself. 
a gift is not itself a substantial obstacle). But as we have seen, the Casey plurality's suggestion to this effect should not be taken seriously because the dehberate frustration of a right does not qualify as a legitimate government purpose. ${ }^{274}$

If we take Regulations $\mathrm{A}, \mathrm{B}$, and $\mathrm{C}$ as illustrative of imcidental, targeted, and purposeful burdens, respectively, it seems reasonably clear how the law should and does treat the first and last categories. Incidental burdens are subject to the substantiahty threshold, whereas purposeful burdens are not. What about the middle category targeted, nonpurposeful burdens?

Casey and Zablocki suggest that such burdens must cross the substantiality threshold for heightened scrutiny to apply in the privacy context. Ward v. Rock Against Racism ${ }^{275}$ suggests a similar result for content-neutral regulations of speech. Moreover, my proposed explanation of this result - that constitutional rights come with a built-im allowance for restrictions desigued to serve some vahd purpose other than merely frustrating the exercise of the right - implies that targeted, nonpurposeful burdens on any fundamental right must reach the substantiality thresliold in order to trigger lieiglitened scrutiny. ${ }^{276}$

There is one large and important category of rights, however, for which this proposition should not hold. These are riglits that contain norms of neutrahty at their core. The classic instance of a neutrality norm is the Fourteenth Amendment's Equal Protection Clause. In Washington v. Davis, ${ }^{277}$ the Supreme Court held that a person does not state a claim of racial discrimination in violation of the Equal Protection Clause ${ }^{278}$ merely by alleging that a government policy has the

274 I do not claim that Regulation $C$ is irrational. The penalty of disinheriting one's heirs is a perfectly rational approach to deterring suicide. But if physician-assisted suicide is a fundamental right, as I am assuming here, then the goal of deterring suicide - as opposed to the goal of ensuring that decisions to commit suicide are fully informed - is not a legitimate one.

27549 I U.S. 78I (1989).

276 Such a test will permit some minor, purposeful burdens to escape heightened scrutiny, because absent heightened scrutiny, it is often difficult to discern the purpose of a law. See City of Richmond v. J.A. Croson Co., 488 U.S. 469, 493 (I989) (O'Connor, J., for a plurality); Sanford Levinson, Identifying the Compelling State Interest: On "Due Process of Lawmaking" and the Professional Responsibility of the Public Lawyer, 45 HASTINGs L.J. 1035, 1044-50 (1994) (suggesting that under a legal process conception of strict scrutiny, courts serve the function of ensuring that the legislature has fairly and openly considered claims of right); cf. Stanley Ingber, The Demise of Dialogue: Commentary on Perry and Nagel, 55 ALb. L. REv. 583, 589 (1992) (noting that when courts ignore incidental burdens, no government official weighs the rightholder's claim, because the "very general applicability of the regulations involved suggests that the enacting institutions ... may well not have considered ... the significance of their actions as they affect constitutional values").

277426 U.S. 229 (1976).

278 Davis actually involved the equal protection component of the Fifth Amendment's Due Process Clause, because it was a suit against the District of Columbia. See id. at 239 (citing Bolling v. Sharpe, 347 U.S. 497, 498-500 (I954) (invalidating, under the Fifth Amendment, racial segregation in District of Columbia schools)). 
effect of burdening persons of one race more severely than persons of another race. ${ }^{279}$ Instead, the plaimtiff must show that the government has purposefully discriminated on the basis of race.

If the right to equal protection were hike other rights, one might think that when the government uses race for some purpose other than simply disadvantaging persons based on race, such a targeted but nonpurposeful regulation would receive deferential scrutiny. But the Supreme Court has not adopted this approach. The Court now strictly scrutinizes any conscious, race-based distribution of burdens and benefits. ${ }^{280}$ Indeed, even those Justices who have been inost sympathetic to government programs designed to benefit traditionally disadvantaged racial groups advocate intermediate scrutiny, 281 rather than complete deference or the de facto deference of United States $v$. O'Brien. ${ }^{282}$

As I note elsewhere, the Supreme Court "views the drawing of various nonneutral lines as a constitutional violation, irrespective of the practical effect those lines have on the affected persons." ${ }^{283}$ In this sense, equal protection acts as a structural provision of the Constitution, much like federalism or separation of powers. Although the interests of individuals provide the ultimate justification for the requirement of equal protection, in any particular case it operates as a bar to certain government actions whether or not those actions implicate the interests that gave rise to the equal protection principle in the first place. ${ }^{284}$

279 See id. at 248 .

280 See Adarand Constructors, Inc. v. Pena, Ir5 S. Ct. 2097, 2rr2-13 (r995) (overruling the application of intermediate scrutiny to federal race-based classification in Metro Broadcasting, Inc. v. FCC, 497 U.S. $547,564-65$ (1990)).

281 See Regents of the Univ. of Cal. v. Bakke, 438 U.S. 265, 361 (1978) (opinion of Brennan, White, Marsliall \& Blackmun, JJ., concurring in the judgment in part and dissenting in part) ("[B]ecause of the significant risk that racial classifications establislied for ostensibly benign purposes can be misused, .... it is inappropriate to inquire only whether there is any conceivable basis that might sustain sucl a classification."). In this context, consider Justice Stevens's view that a congressional program granting Japanese-American veterans an extraordinary preference in government employment would impose only an "incidental burden" on those denied the benefit. Adarand Constructors, Irs S. Ct. at $212 \mathrm{I}$ (Stevens, J., dissenting). The burden is incidental in the sense that the purpose of the program is not to harm persons who do not qualify for the benefit. If we focus on targeting, however, the burden is direct because the government policy, by its terms, classifies based on race. For Justice Stevens and the other dissenters from the Court's application of strict scrutiny to all governmental use of racial classifications, purposeful harming of a racial group is necessary for strict scrutiny to apply. Note, however, that the dissenters would judge nonpurposeful targeting based on race - for example, most affirmative action programs - by intermediate rather than deferential scrutiny. They would not refer to a substantiality threshold, even thougl they might consider the burden imposed to be incidental.

282 39I U.S. 367 (I968).

283 Dorf, supra note I, at 260; see also id. at $260 \mathrm{n} .93$ (stating that Shaw v. Reno, $113 \mathrm{~S}$. Ct. 2816 (I993), "provides dramatic confirmation of this view of equal protection").

284 Asking what injury the white voters have suffered in the recent race-based redistricting cases illustrates the point particularly well. According to Justice Stevens, they "have not suffered 
If we understand equal protection as a structural provision of the Constitution - as I am suggesting that the Court does - then we do not need to explain the fact that targeted uses of race trigger heightened scrutiny even absent an illicit purpose or a substantial burden, whereas targeted regulations of abortion (or speech or free exercise) trigger heightened scrutiny only if they serve an illicit purpose or impose a substantial burden. There is no explaming to do because the violation of a structural norm is a wrong in itself, ${ }^{285}$ whereas the violation of a substantive norm is not.

Explanation is necessary, however, for those situations im which the mere targeting of a substantive right triggers heightened scrutiny even absent an illicit purpose or a substantial burden. This pattern occurs most prominently under existing doctrine when courts consider content-based regulations of speech. The explanation now becomes apparent: the right to free speech is both substantive and structural. As has been widely recognized, the free speech riglit serves both instrumental and noninstrumental purposes. ${ }^{286}$ As a noninstrumental inatter, freedom of expression may be seen as essential to personhood and, thus, a substantive right of great value to individuals. Simultaneously, a regine of free speech instrumentally facilitates self-government. Content-based and viewpoint-based regulations of speech pose a threat to this instrumental goal through their systemic effects. According to the canonical view, they distort the marketplace of ideas and, for this reason, must be strictly scrutinized even if their effect on any given individual is relatively minor. In short, content-based and viewpoimt-based regulations of speech are structurally problematic and should therefore be treated more like infringements of the equal pro-

any legally cognizable injury." Miller v. Johnson, II5 S. Ct. 2475, 2497 (I995) (Stevens, J., dissenting). The majority's response - that race-based classifications always injure the persons classified, see Miller, IIS S. Ct. at 2482 - is merely another way of saying that a conventional injury stemming from the use of race is not necessary to trigger strict scrutiny.

285 The equal protection guarantee differs from other structural norms in that it is only presumptive. A prima facie infringement of the right to equal protection may be justified if strict scrutiny is satisfied. In contrast, a separation of powers violation is per se unconstitutional, although of course, the determination whether there has been a separation of powers violation will often involve a weighing of competing interests. See, e.g., Morrison v. Olson, 487 U.S. 654, 685-96 (I988).

286 Alexander Meiklejohn developed the best-known account of free speech as a means toward achieving self-government. See AleXANDER MEIKLEjoHn, Political FreEdom passim (ig60); alexander Meiklejohn, Free Speech and Its Relation to Self-Government passim (I948). More recently, Cass Sunstein has been the leading proponent of an instrumental view of free speech. See Cass Sunstein, Democracy and the Problem of Free SpeEch at xi-xx (I993). Despite the emphasis on self-government, instrumentalists typically find a way to conclude that the free speech principle extends beyond political speech. See, e.g., J.M. Balkin, Populism and Progressivism as Constitutional Categories, I04 YALE L.J. I935, I963 (I995) (reviewing CASS Sunstein, Democracy and the Problem of Free SpeECh (1993)). In contrast, nominstrumentalists typically ground the free speech right in a conception of individual autonomy. See, e.g., C. Edwin Baker, The Process of Change and the Liberty Theory of the First Amendment, 55 S. CAL. L. REV. 293, 33I-37 (I98I). 
tection principle than like infringements of rights that do not contain equality norms.

I slould note that many rights contain equality norins and may be viewed as structural as well as substantive. For example, even under Smith, a law that targets religion is subject to constitutional strict scrutiny. ${ }^{287}$ This principle not only prevents petty harassment of religious institutions, but also serves the important structural goal of inaintaining civil peace througl a governmental stance of neutrality toward religion. ${ }^{288}$ Similarly, to the extent that restrictions on the abortion riglit constitute sex discrimination - as suggested by a majority of the Court in Casey 289 but not by other Supreme Court decisions $^{290}$ - all targeted regulations of abortion ought to be subject to heiglitened scrutiny because they infringe the structural goal of equal protection. ${ }^{291}$

In sum, the law ought to - and to a large extent does - distinguish among purposeful, targeted, and incidental burdens on primary conduct riglits. Heightened scrutiny should apply to all purposeful restrictions of substantive rights, to all regulations targeted at rights that contain norms of equal treatınent (including free speech and free exercise), to other targeted regulations that substantially burden rights, and to incidental restrictions that similarly place substantial burdens on rights. This general framework has been largely implicit in the law. Converting it into an explicit formulation, as I propose here, will enable courts to see inore clearly the nature of the interests at stake in cases involving fundamental rights.

\section{B. Incidental Burdens and Facial Challenges}

Despite the importance of looking to the nature of the particular right at stake in any given case, some additional features of the inci-

287 See Church of the Lukumi Babalu Aye, Inc. v. City of Hialeah, Ir3 S. Ct. 2217, 2226-27 (1993).

288 Of course, government neutrality is a broad goal of both religion clauses. As the Court stated in Walz v. Tax Commission of New York, 397 U.S. 664 (1970), the "general principle deducible from the First Amendment and all that has been said by the Court is this: that we will not tolerate either governmentally established rehigion or governmental interference with religion." Id. at 669 .

289 See Planned Parenthood v. Casey, 505 U.S. 833, 852 (I992) ("Her suffering is too intimate and personal for the State to insist, without more, upon its own vision of the woman's role, however dominant that vision bas been in the course of our history and our culture.").

290 See Bray v. Alexandria Women's Health Chinic, II3 S. Ct. 753, 759 (1993) (holding that opposition to ahortion does not constitute animus toward women for purposes of conspiracy liability under 42 U.S.C. § 1985(3) (1988)); Geduldig v. Aiello, 417 U.S. 484, 494-95 (1974) (holding that the exclusion of pregnancy from a state disahility-benefits program does not constitute sex discrimination).

291 The Supreme Court subjects gender classifications to intermediate rather than strict scrutiny, see, e.g., Craig v. Boren, 429 U.S. 190, 197 (1976), although it sometimes blurs the distinction, see J.E.B. v. Alabama ex rel. T.B., I14 S. Ct. 14I9, 1425 (1994) (applying "heightened scrutiny" to gender-based distinctions). 
dental burden question merit general discussion. Among these issues is the relation between the proper treatment of incidental burdens and that of facial challenges. The incidental burden question is, in soine sense, the mirror image of the facial challenge question. In a paradigmatic facial challenge case, the government attempts to apply a constitutionally or otherwise generally infirm law to a person whose own conduct is not protected. In contrast, in an incidental burden case, the government attempts to apply a generally valid law in a way that imfringes on a person's rights in the particular circumstances. We may summarize the two situations as follows: facial challenge - unprotected conduct, generally imvalid law; incidental burden - protected conduct, generally vahd law. What implications do the doctrimes of facial challenges and of incidental burdens have for one another? To answer this question, let me begin with a brief summary of facial challenge doctrine.

The Supreme Court has sometimes stated that a person will prevail in challenging a law on its face only if she can show that "no set of circumstances exists under which the [law] would be valid."292 In other words, if a law has any constitutional applications, it will be deemed facially valid. An exception for the First Amendment overbreadth doctrine - which permits a person whose own speech rights are not violated to object to a law's scope as a means of preventing a chilling effect on the protected First Amendment activity of others typically accompanies statements of the general rule. ${ }^{293}$

As I argue elsewhere, however, the "no-set-of-circumstances" test neither accurately reflects the bulk of the Supreme Court's actual decisions nor is sound as a matter of principle. ${ }^{294}$ The test that I propose recognizes that a law's facial vahdity is ordinarily a question of severability. If a rule of law would be vahd as applied to some cases but invalid as applied to others, then the government may apply it in the former cases if, but only if, the invalid applications may be severed from the valid ones, thus leaving only a valid law. ${ }^{295}$ In the case of a facial cballenge to a state law, state principles of statutory construction will govern severability, and likewise in the case of a facial challenge to a federal law, federal principles of statutory construction will govern severability. ${ }^{296}$

Moreover, the overbreadth exception is broader than commonly recognized. The Supreme Court has applied the overbreadth doctrine in most of its right-to-privacy cases. ${ }^{297}$ The Court's approach is sensi-

292 United States v. Salerno, 48 I U.S. 739, 745 (1987).

293 See id.

294 See Dorf, supra note I, at $236,238$.

295 See id. at $249-51$.

296 See id. at $283-93$.

297 See id. at $271-76$. 
ble because the overbreadth doctrine prevents courts from presuming a law's unconstitutional applications to be severable - and thereby dismissing a facial challenge - in First Amendment cases and in all other cases in which a constitutional right may be susceptible to a chilling effect. ${ }^{298}$ These latter cases typically involve the right of privacy. 299

The intersection of facial challenge doctrine and incidental burden doctrine creates an apparent problem. As we have seen, virtually every law can, under some circumstances, pose an unconstitutional incidental burden on a First Amendment or privacy right. Given that the overbreadth doctrine prohibits severing these unconstitutional applications from the law's constitutional ones, is every law facially unconstitutional because of the possibility of incidental burdens?

Overbreadth doctrine includes a provision that avoids sucli an absurd conclusion. In Broadrick v. Oklahoma, ${ }^{300}$ the Supreme Court stated that the rationale for the overbreadth doctrine "attenuates as the otherwise unprotected behavior that it forbids the State to sanction inoves from 'pure speech' toward conduct and that conduct - even if expressive - falls within the scope of otherwise valid criminal laws."301 In other words, free speecls overbreadth doctrine does not typically apply to incidental burdens on speech arising out of speechneutral laws. ${ }^{302}$ As the Court established in Broadrick, overbreadth doctrine only operates when a law has a great many unconstitutional applications. ${ }^{303}$ Generalizing, we can say that overbreadth doctrine for any given right will not apply to incidental burdens on that right.

For a successful overbreadth claim, the Broadrick Court thus requires what it terms "substantial" overbreadth. ${ }^{304}$ This requirement should not be confused witli the test that I have proposed througliout this Article - that an incidental burden be substantial in order to trigger heightened scrutiny. To trigger heightened scrutiny, an incidental burden inust be substantial in the sense that it imposes a weighty hardship on the rightholder. For overbreadth doctrine to invalidate a law because it imposes incidental burdens, the number of cases in

298 See id. at $268-71$.

299 See id. at $268-76$.

3004 II3 U.S. 601 (1973).

301 Id. at 615 .

302 The Court's characterization of the particular activity at issue in Broadrick as conduct rather than speech is somewhat curious. The challenged provision of Oklahoma's Merit System of Personnel Administration Act prohibited civil servants from engaging in various political activities that the state would have had no power to prohibit the general public from doing. See id. at 602-06. Although the activities in which the petitioners had engaged - partisan political affairs, including soliciting money - may not have been pure speech, they were certainly the kinds of activities protected by the First Amendment. Thus, it may be somewhat inaccurate to characterize the burden posed by the law challenged in Broadrick as incidental.

303 See id. at 615.

304 See id. 
which the law imposes such burdens, represented as a fraction of the cases in which the law applies, must be substantial. Because the substantiality condition from Broadrick will rarely, if ever, be true of a generally vahid law, we need not fear that the intersection of the incidental burden and facial challenge doctrines will result in the wholesale invalidation of legislation.

\section{The Substantiality Threshold}

The analysis presented by this Article suggests a rough-and-ready test for determining which burdens on rights automatically trigger heightened scrutiny and which burdens must first reach the substantiality threshold before heightened scrutiny ought to apply. We are still left with the difficult task of determining what constitutes a substantial burden. Throughout this Article, I have suggested that a focus on alternative means and a generous apphication of neutrahty concepts should guide the substantiality inquiry. But these tools are not by themselves sufficient, as a class of examples illustrates.

Suppose that Susan wishes either: to buy commercial airtime on a local radio station to express her views with respect to an issue of great importance to her; or to purchase an airhine ticket to travel on a pilgrimage to a distant holy site; or to pay for an abortion at a forprofit private hospital. Susan, however, is a struggling student wlio lacks the funds to carry out any of these plans. She would like to use her computer to transfer a sum of money from the account of a large pension fund to her own bank account, and then use the money to finance one of these activities. Unfortunately for Susan, this would violate the criminal law prohibiting larceny. Must the state satisfy some form of heightened scrutiny to apply its larceny law to any of the three planned courses of conduct?

In quantitative terms, the burden that the larceny law imposes on Susan's ability to exercise her rights is substantial. In the absence of the larceny law, she could simply appropriate the large suin of money which she needs. To be sure, the larceny law is in no way directed at protected conduct, but that only means that the burden imposed inust be substantial for heightened scrutiny to apply. For Susan, it appears that the burden is substantial.

Yet surely the state should not have to satisfy heiglitened scrutiny in order to enforce its larceny law against someone who wishes to use her ill-gotten gains to finance conduct that is protected against coercive governmental restriction. The question becomes whether we can distinguish this example in a principled way. The question is of critical importance, because as legal realists and their modern-day intellectual successors correctly note, nearly all social relations are in some 
real sense the product of law in a complex society such as ours.305 A person's ability to exercise her rights will be substantially affected and inay be substantially burdened by, annong other things: how much of her income the government takes in taxes; what services the government provides to facilitate a variety of activities, including but not limited to protected activities; what laws govern property and the enforcement of contracts; and so forth.

A variety of principles are available to distinguish examples such as these. Most important, perhaps, is the distinction between positive and negative rights. A right to do $x$, it is often said, is not a right to a government subsidy to do $x .{ }^{306}$ Rather, a right to do $x$ is merely a right to avoid government interference with one's efforts to do $x$. This response will not satisfy the legal reahist, however, because it rests on the very public/private distimction that the realist critiques. ${ }^{307}$ If all social relations are the product of law, then the government cannot disclaim responsibility for events in the private sphere, because private events too can be traced to government policy.

Of course, the pubhic/private distinction, even if theoretically problematic in the way that legal realists clain, is firmly rooted in constitutional jurisprudence. ${ }^{308}$ Thus, pointing out that an argument rests on this distimction hardly discredits the argument. Moreover, a court can justify the distinction between positive and negative rights by primciples of separation of powers (and, in the case of state law, federahism) regardless of what one thimks of the distinction as a matter of rights theory. Representative bodies control the power of the purse, and thus, courts will order the expenditure of money in only the most unusual of cases. ${ }^{309}$

How potent is the positive/negative distinction? In the examples given above, Susan arguably does not claim a right to a government subsidy to exercise her rights. Rather, she clains an exemption from a generally applicable law governing conduct by private parties. Invok-

305 For the modern version of this argument as it applies to free speech see SUNSTEIN, cited above in note 286 , at $17-5 \mathrm{I}$, in which he argues for "A New Deal For Speech" that recognizes threats to free speech from background laws. But see Alexander, supra note 98, at 930-3I (arguing that Sunstein's analysis fails because all background laws threaten someone's speech).

306 See, e.g., Rust v. Sulhvan, 500 U.S. I73, 196-200 (1991); Harris v. McRae, 448 U.S. 297, 316-17 (1980); Maher v. Roe, 432 U.S. 464,469 (1977). But see, e.g., Gideon v. Wainwright, 372 U.S. $335,342-46(1963)$ (holding that an indigent criminal defendant has a Sixth Amendment right to a government-subsidized attorney).

307 See Balkin, supra note 286 , at Ig68 (noting that the legal realist critique of the public/ private distinction "softens the distinctions between positive and negative liberties").

308 Cf. Trube \& DORF, supra note 55, at 70-71 (noting that the Takings Clause, by its terms, is inconsistent with the legal realist view of property).

309 See Missouri v. Jenkins, 495 U.S. 33, 50-51 (1990) (holding that, as a matter of comity, a federal district court could not order a local property tax increase as a remedy for unconstitutional racial segregation in education without first assuring itself that no less drastic alternative existed). 
ing the positive/negative distinction in this context recasts the intertwined/facilitative distinction discussed in the free speech section. 310 Even from Susan's perspective, the burdened act - electronically stealing inoney - is at inost facilitative of, rather than intertwined with, the protected conduct. Under one reading of Arcara v. Cloud Books, Inc., ${ }^{311}$ therefore, we might say that no matter how substantial a burden the larceny prohibition poses, it is not a burden on protected conduct. ${ }^{312}$ Susan's lack of money impedes her ability to exercise her rights, and the larceny prohibition is only coincidentally connected to her rights.

Recall from our free speech discussion, however, that the distinction between facihtative and intertwined acts will often be difficult to maintain and, in any event, cannot dispose of all the substantial burdens that we might intuitively wish to exempt from heightened scrutiny. ${ }^{313}$ Thus, even allowing for a distinction between positive and negative rights and even discounting burdens on inerely facilitative conduct, some incidental burdens will still trigger heightened scrutiny. This should not be cause for great alarm. In most of the troubling cases, the government will eàsily ineet its justificatory burden. For example, we need not worry that subjecting the law that prohibits murder to heightened scrutiny in the case of ritual human sacrifice will insulate that practice from punishment.

Sometimes, of course, the government will not be able to justify what appears to be a substantial incidental burden on a right, but this failure does not necessarily undermine the approach that I have outhined. We should expect that taking incidental burdens seriously will sometimes, perhaps even often, impose additional requirements on governinent.

Consider the following hypothetical case: Dorothy's religion obligates her to take a hot air balloon pilgrimage from her hoine in Kansas to the holy land of $\mathrm{Oz}$ during a particular holy week at some point prior to her twenty-first birthday. Dorothy, now twenty years old, has been saving money since she was a child to be able to afford her ticket to $\mathrm{Oz}$. The day before Dorothy's scheduled Kansas-to-Oz flight during the holy week, the relevant Kansas authorities announce that there will be no hot air balloon flights for the next week in order that they can conduct spot checks of the safety equipment of all hot air balloons in the state. Does RFRA prevent Kansas from grounding Dorothy's balloon during the crucial week?

In response to questions such as this one, I find myself teinpted immediately to try to find ways of deeming RFRA inapplicable. Is

310 See supra pp. 1206-08.

311478 U.S. 697 (I986).

312 See supra pp. 1205-06.

313 See supra pp. 1206-08. 
Dorothy seeking affirmative aid from the government? Apparently not, because she has purchased a ticket from a private balloonist. Perhaps the regulated act is merely facilitative. This objection also fails, because Dorothy has an obligation not merely to arrive in $\mathrm{O} z$, but to travel there by hot air balloon from Kansas during this particular week - the very act prohibited by the state. Thus, under RFRA the restriction inust satisfy strict scrutiny.

Even upon this conclusion, I find that I try to assure myself that the law will be upheld. Surely ensuring air balloon safety is a compelling imterest. It may well be, but it will hardly be true that the state's pohicy is the least restrictive means of advancing its interest. The state could imspect the safety equipment of the balloon that Dorothy intends to fly before imspecting the equipment of other balloons. This special treatment will certainly be administratively awkward for the regulatory agency, which would like to schedule inspections at its convenience, but the inefficiency seems minor. Dorothy goes to $\mathrm{Oz}$.

$I$ doubt that $I$ am alone in my tendency to deem most incidental burdens permissible. Judges with real docket pressure are at least as concerned with the floodgates problem as academics are. Dorothy's case, whimsical as it may be, should thus serve as a warning. Even when a law has the effect of rendering impossible the performance of a required religious act, we feel a strong pull toward sustaining government power. Without minimizing the risk of over-enforcement of rights against mcidental burdens, the real danger probably lies in the other direction. Recall that in Smith itself, even Justice O'Connor, who disagreed with the majority's approach, would have held that the peyote prohibition survived strict scrutiny ${ }^{314}$ - despite the state's failure to show that sacramental peyote use seriously harmed third parties or even the users themselves.

\section{Nonprimary Conduct Rights}

Although a comprehensive treatinent of all incidental effects in constitutional law is beyond the scope of this Article, the analysis of incidental burdens on primary conduct rights suggests a number of strategic starting points for evaluating burdens on other kinds of constitutional rights. In this concluding section, I consider two related factors which seem especially important: the reasons for recognizing a right and the scope of the interests protected.

How can analysis of the reasons for recognizing a right be useful in assessimg burdens on nonprimary conduct rights? Consider this question in the context of the Fifth Amendment right against self-incrimination. In Colorado v. Connelly, ${ }^{315}$ the Supreme Court judged the

314 See Employment Div. v. Smith, 494 U.S. 872, 894-96, 903 (I990) (O'Connor, J., concurring).

315479 U.S. 157 (1986). 
admissibility of a murder confession by a defendant suffering from a psychosis that caused him to hear what he perceived as commands from God. ${ }^{316}$ The defendant argued that his confession was inadmissible under the Fifth Amendment's requirement that "[n]o person shall .. . be compelled in any crinimal case to be a witness against himself."317 Relying on Supreme Court decisions holding voluntariness to be the sine qua non of admissibility under the Fifth Ainendinent, the defendant argued that his case fell within the prohibition's hiteral text, because the voices in his head compelled him to be a witness against himself. ${ }^{318}$ The Court rejected the claim because of its view concerning the purpose of the prohibition against coerced confessions.

According to the Connelly Court, the "integral element" of an unconstitutional, coerced confession is "police overreaching."319 Viewed in this fashion, imdividuals do not have a protected interest in freedom from coercion as such. Instead, the Fifth Amendment grants a right against compelled testimony as a means of restraining the police. In contrast, if the right against compelled testimony is valuable in itself in the same way that primary conduct rights are, then that right would protect against imcidental burdens - presumably including the mcidental burden that arises out of a pohice officer's mere presence in the vicinity of someone suffering a psychosis like Connelly's. Because the Court perceived the prohibition on compelled testimony as a restramt on the police, ${ }^{320}$ however, it defined the right as a right against testimony compelled by the pohce. The Court's understanding of the reasons for recognizing the right leads to a definition of the right that excludes the possibility of imcidental infringement.

As we saw in section II.C, some primary conduct rights serve as both restrictions on government power and affirmative entitlements of the imdividual. ${ }^{321}$ Nonprimary conduct rights may have this feature as well. The Fourth Ainendment right agaimst unreasonable searches and seizures is one example. Its first clause proclaims: "The right of the people to be secure in their persons, houses, papers, and effects, against unreasonable searches and seizures, shall not be violated ...."322 The reasonableness requirement suggests a direct concern with pohice conduct, whereas the text also appears to protect individual interests im privacy (in the sense of secrecy and security rather than in the sense described im section II.C above). Focusing on one

316 See id. at 159 .

317 U.S. CONST. amend. V.

318 See Connelly, 479 U.S. at 164 (discussing defendant's reliance upon Blackburn v. Alabama, 36I U.S. I99 (I960), and Townsend v. Sain, 372 U.S. 293 ( $(963)$ ).

319 Id.

320 The Court also recognized that coerced confessions are often unreliable but stated that this issue is a subconstitutional question of state evidence law. See id. at $16 \%$.

321 See supra p. 1227.

322 U.S. CONST. amend. IV. 
goal or the other may lead to different results. For instance, suppose that a police officer acting in good faith reasonably believes that she has probable cause to searcl a suspect's home and that exigent circumstances preclude obtaining a warrant prior to a search. If a court later determmes that probable cause did not exist, should the officer's conduct be understood to violate the Fourth Amendment?323

A court would, no doubt, wish to consider a number of factors peculiar to the particular context. If the issue arises in the course of a suppression inotion prior to a criminal trial, the court will want to balance the deterrent effects of exclusion of arguably illegally seized evidence against the social costs of freeing a potentially guilty person. But certamly one factor relevant to the analysis is the degree to which we believe that the Fourth Amendment serves to protect interests of value to individuals. A court that considers individual privacy a key concern of the Fourth Amendment will be more likely to find that the officer's good faith is irrelevant, because even absent deliberate police overreaching, the invasion of privacy constitutes a substantial harm. The incidental effects will inatter to such a court.

That some right protects interests of value to the rightholder is not, however, a sufficient condition for applying heiglitened scrutiny to substantial imcidental burdens on the exercise of that right. Consider the Fifth Amendment's Takings Clause, which commands that "private property" shall not "be taken for public use without just compensation." 324 The Takings Clause protects an interest of value to individuals - the right to own private property. Yet the Supreme Court has never suggested that laws having the incidental effect of substantially devaluing private property require just compensation, and for good reason. Every regulation has the potential to effect the value of property, often substantially. For example, laws siting locally undesirable government functions, such as sewage treatinent or drug rehabilitation, inay cause property values to decline substantially. The discontinuation of appropriations for a military base may severely undermine the surrounding local economy and property values. Laws redrawing school district lines to achieve racial desegregation may lead to flight and property devaluation.

Consequently, although the Supreme Court has recently looked favorably on takings claims, ${ }^{325}$ it has not come close to employing the

323 Compare United States v. Leon, 468 U.S. $897,922-23$ (1984) (holding that the Fourth Amendment exclusionary rule does not apply to evidence seized pursuant to a facially invalid warrant when an officer in good faith reasonably believed that the warrant stated facts sufficient to constitute probable cause) with Scott v. United States, 436 U.S. 128, 138 (1978) (holding that bad faith does not constitute a Fourth Amendment violation where objective facts known to an officer supported a wiretap).

324 U.S. CONST. amend. V.

325 See Dolan v. City of Tigard, II4 S. Ct. 2309, 2322 (I994) (finding a taking when a city required a hardware store owner to dedicate land to a public walkway and bicycle path in ex- 
substantial burden framework that RFRA requires for incidental burdens on religion. Even for direct regulations of property use, so long as the regulation is "related both in nature and extent" to the property owner's actions, ${ }^{326}$ the Court requires the destruction of "economically viable use" of the regulated property before ordering just compensation. ${ }^{327}$ Even then, the Court will not require compensation if the regulation merely prohibits a use that constitutes a violation of the background principles of nuisance or property law. ${ }^{328}$

The Court's refusal to treat incidental burdens on property as takings can be justified on more than a floodgates rationale. Property rights differ from the primary conduct rights discussed in Part $I I$ in a crucial respect. For a primary conduct right, we can describe what it means to exercise the right without any reference to the state. The conduct of giving a speech, of ritually ingesting peyote, or of liaving an abortion is a perfectly coherent concept. As the legal realists argued, however, the concept of property ordinarily refers to the state's willingness to assist the propertyholder in defeating the claims of others. ${ }^{329}$ The point is not that property rights consist of whatever rights the state chooses to recognize. The same positivist claim could be made about primary conduct rights. Rather, the realists showed that a web of government regulation creates the concept of property itself. Hence, any significant alteration in the web not only could, but typically will, burden property rights.

Finally, consider the nonprimary conduct right to equal protection of the laws. In section III.A, I argued that the Supreme Court understands this right to serve a structural function and thus subjects targeted, nonpurposeful burdens to heightened scrutiny without regard to whether these burdens are substantial. 330 How should truly mcidental burdens on the equal protection right be treated?

We may think of laws that have a disparate impact on racial (or other suspect) minorities as incidentally burdening the riglit to equal protection. Existing doctrime does not require heightened scrutiny of

change for a permit to expand her store and pave her parking lot); Nollan v. California Coastal Comm'n, 483 U.S. 825,839 ( 1987 ) (finding a taking when a commission required an easement along beachfront property as a condition for a building permit).

326 Dolan, II4 S. Ct. at 2320.

327 Lucas v. South Carohina Coastal Council, 505 U.S. I003, I0I6 (I992) (quoting Agins v. City of Tiburon, 447 U.S. 255,260 (I980)) (internal quotation marks omitted and emphasis omitted).

$328 \mathrm{See}$ id. at 1029-30.

329 See, e.g., Morris Cohen, Property and Sovereignty, I3 CoRnell L.Q. 8, I2 (I927). See generally C. Edwin Baker, Property and Its Relation to Constitutionally Protected Liberty, I34 U. PA. L. REV. 74I, 74I-42 (I986) (disaggregating property into the multiple purposes that it serves and arguing that, by itself, the concept of property deserves less constitutional protection than most constitutionally protected liberty).

330 See supra pp. I237-39. 
such laws. ${ }^{331}$ This seems sensible. As a principle designed to restrain the government from acting based upon racial or other suspect criteria, equal protection is not offended when the government does not predicate its decisionmaking on such criteria, even though the action taken has the incidental effect of disproportionately burdening a racial mimority.

Further exammation of current doctrine reveals a puzzle, however. The Court repeatedly affirms the principle that equal protection rights are "personal."332 As I have argued throughout this Article, laws infringing personal rights harm the rightholder regardless whether they are directed at those rights.

The solution to the puzzle can be found in the peculiar nature of the "personal" right to equal protection. According to the Supreme Court, it is a personal right not to be burdened or denied a benefit on the basis of a suspect classification. The Court may recognize the right to be personal, but its scope is apparently defined in relation to government action. Equal protection does not protect an interest of an mdividual that exists independently of the government's conduct with respect to that person. We would not expect a right so defined to receive protection against incidental burdens, because by definition, incidental effects do not burden the right.

Equal protection law as it stands is therefore consistent with the framework proposed in this Article. However, consistency with the conceptual framework is no guarantee of correctness. The framework set forth here tells us how the law should deal with various kinds of infrimgements of given rights, but it does not tell us how to give substantive content to those rights.

For example, suppose that the Court were to rule that equal protection does not entail the structural primciple of race-neutrahty; rather, it champions the principle that government may not perpetuate racial subordination. This second primciple would also be structural, in the sense that it focuses on the himits of government power instead of the mterests of mdividuals. Yet under the anti-subordination principle, it would be entirely appropriate to apply strict scrutiny to government programs having a disparate impact on racial minorities. Seen through the lens of our alternative equal protection principle, the disparate impact would no longer be an incidental effect. If the disparate impact were sufficiently severe as measured by the appropriate substantive test, it would contribute to racial subordination and, thus,

331 See Village of Arlington Heights v. Metropolitan Hous. Dev. Corp., 429 U.S. 252, 264-65 (1977) ("[O]fficial action will not be held unconstitutional solely because it results in a racially disproportionate impact." (citing Washington v. Davis, 426 U.S. 229, 244-45 (1976))).

332 See, e.g., Adarand Constructors, Inc. v. Pena, Ir5 S. Ct. 2097, 2114 (1995) (noting "the long line of cases understanding equal protection as a personal right'). 
directly infringe the alternative equal protection principle prohibiting the perpetuation of racial subordination.

The incidental burden framework itself cannot choose between a regime of race-neutrality and a regime of anti-subordination any more than it can tell us whether the Due Process Clause encompasses a right to abortion or whether the First Amendinent encompasses a riglit to burn a flag. These decisions require substantive interpretation of the relevant constitutional rights. The framework described in this Article is useful - and only useful - im delineating the scope and nature of the protection that rights should receive once they are recognized and defined.

\section{CONCLUSION}

Conventional sources of constitutional meaning all point toward treating incidental burdens as infringements on fundamental constitutional rights to engage in primary conduct. Yet to treat every imcidental burden as calling for heightened scrutiny would render effective government regulation impossible in a wide range of situations. As a result, the Supreme Court has developed limiting principles, albeit haltingly and sometimes unwittingly. The sensible limiting principle toward which both Congress and the Court have been moving is a substantiality threshold. Under this approach, laws that are designed to frustrate or that substantially burden the exercise of a right must be subject to heightened scrutiny. The limiting principle is itself subject to an important reservation, however: it does not fully apply to riglits to equal treatment.

This summary is an amalgam of existing doctrine and proposed inprovements. Although it provides a useful starting point for analyzing claims that the government has infringed a fundamental right, it is only a starting point. In any real case, sorting out the differences between purposeful, targeted, and incidental burdens will clarify but will not answer the difficult questions about the scope of an asserted right and the government's power to override it. 